ФЕДЕРАЛЬНОЕ ГОСУДАРСТВЕННОЕ БЮДЖЕТНОЕ ОБРАЗОВАТЕЛЬНОЕ УЧРЕЖДЕНИЕ

ВЫСШЕГО ПРОФЕССИОНАЛЬНОГО ОБРАЗОВАНИЯ АДЫГЕЙСКИЙ ГОСУДАРСТВЕННЫЙ УНИВЕРСИТЕТ

\author{
М.E. Ордынская
}

\title{
ОСОБЕННОСТИ УЧЕТА В ТОРГОВЛЕ
}

\section{(краткий курс лекций)}


УДК $657.1(075.8)$

ББК 65.052 я73

O 65

Ордынская М.Е.

Особенности учета в торговле. Краткий курс лекций. [Электрон. дан. (4,33 Мб)]. М айкоп: АГУ, 2011. 1 электрон. опт. диск (CD-ROM). - Систем. требования: Intel Pentium (или аналогичный процессор других производителей) 1 ГГц; 512 Мб оперативной памяти; 5 Мб свободного дискового пространства; привод CD; операционная система Microsoft Windows 2000 SP 4 / XP SP 2 /Vista (32 бит)IE 6.0; Adobe Reader 7.0 (или аналогичный продукт для чтения фрайлов формата pdf).

Номер гос. регистрации 0321103487

\section{Рецензенты:}

Хуажева А.Ш. - доктор эк ономических наук, профессор, зав. кафедрой учета и финансирования Адыгейск ого государственного университета.

Севастьянова Г.В. - кандидат эк ономических наук, доцент кафедры учета, анализа и статистики фракультета информационных систем в экономике и юриспруденции М айкопск ого государственного технологическ ого университета.

Воитлева 3.А. - кандидат эк ономических наук, доцент кафедры учета, анализа и статистики фракультета информационных систем в экономике и юриспруденции М айкопского государственного технологическ ого университета.

В учебном пособии представлен краткий курс лекций по бухгалтерскому учету в торговле для студентов всех фрорм обучения. Содержит информацию, посвященную отраслевым особенностям торгующих организаций, рассмотрены различные ситуации, связанные с учетом при оптовой и розничной продаже товаров, списание естественной убыли, учет тары и др. В пособие включена корреспонденция счетов, составленная на основе Плана счетов бухгалтерского учета фринансово-хозяйственной деятельности организаций, утвержденного приказом Минфина РФ от 31.10.2000 №94н.

В пособии приводятся контрольные вопросы и тестовые задания с целью закрепления изученного материала.

Предназначено для преподавателей и студентов. Кроме того, учебное пособие будет полезным для практикующих бухгалтеров торговых организаций, аудиторов.

Все права на размножение и распространение в любой форме остаются за авторами. Нелегальное копирование и использование данного продукта запрещено.

Офрормление электронного образовательного ресурса ООО «М ирИТ»

E-mail: mirit.books@gmail.com.

Подп. к использованию 21.11.2011 г.

Объем 4,33 М б

УДК 657.1 (075.8)

ББК 65.052 я73

Номер гос. регистрации 0321103487

(C) АГУ, 2011

(c) Ордынская М.Е., 2011

(С) Оформление. ООО "МирИТ", 2011 


\section{ОГЛАВЛЕНИЕ}

ОГЛАВЛЕНИЕ ..............................................................................3

ВВЕДЕНИЕ

ЛЕКЦИЯ 1. ТОРГОВОЕ ПРЕДПРИЯТИЕ КАК СУБЪЕКТ РЫНОЧНОЙ ЭКОНОМИКИ.......................................................9

1. Торговое предприятие как субъект рыночной экономики .....................9

2. Вопросы для самоконтроля .......................................................................... 14

ЛЕКЦИЯ 2. ОСНОВЫ ОРГАНИЗАЦИИ БУХГАЛТЕРСКОГО УЧЕТА В ТОРГОВЫХ ПРЕДПРИЯТИЯХ ............................15

1. Организация учетной работы на предприятии........................................ 15

2. Учетная политика торгового предприятия .............................................. 21

3. Формы бухгалтерского учета, применяемые торговыми

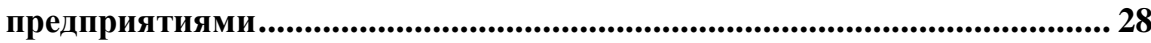

4. Вопросы для самоконтроля ......................................................................... 36

ЛЕКЦИЯ 3. УЧЕТ ПОСТУПЛЕНИЯ ТОВАРОВ ................37

1. Документальное оформление поступления товаров ................................ 37

2. Учет операций по приобретению товаров ................................................... 41

3. Аналитический учет товаров ...................................................................... 52

4. Вопросы для самоконтроля .......................................................................... 57

ЛЕКЦИЯ 4. УЧЕТ РАСХОДОВ ТОРГОВОЙ

ОРГАНИЗАЦИИ ........................................................................58

1. Понятие издержек и расходов .................................................................... 58

2. Синтетический учет издержек обращения ……………………………….... 63

3. Аналитический учет издержек обращения ................................................. 66

4. Учет транспортных расходов ....................................................................... 78

5. Учет издержек обращения на остаток товаров ........................................ 81

6. Вопросы для самоконтроля......................................................................... 84

ЛЕКЦИЯ 5. УЧЕТ ТАРЫ ..................................................85

1. Учет тары ................................................................................................. 85

2. Вопросы для самоконтроля ........................................................................ 93

Ордынская М.Е. Особенности учета в торговле. Краткий курс лекций. $\sim 3 \sim$ 


\section{ЛЕКЦИЯ 6. УЧЕТ ТОВАРНЫХ ПОТЕРЬ, ЗАВЕСА} ТАРЫ И ПЕРЕОЦЕНКИ ТОВАРОВ........................................94

1. Виды товарных потерь ........................................................................94

2.Исчисление и учет естественной убыли товаров .....................................96

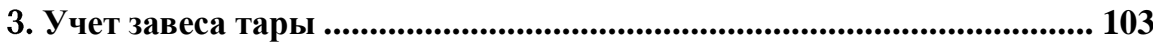

4. Учет потерь при подготовке товаров к продаже..................................... 105

5. Учет переоценки товаров ................................................................ 107

6. Вопросы для самоконтроля........................................................................... 110

ЛЕКЦИЯ 7. ИНВЕНТАРИЗАЦИЯ ТОВАРОВ И ТАРЫ...111

1. Порядок проведения инвентаризации ....................................................... 111

2. Отражение в учете результатов инвентаризации ............................... 117

3. Вопросы для самоконтроля ..................................................................... 122

ЛЕКЦИЯ 8. УЧЕТ ОПТОВОЙ РЕАЛИЗАЦИИ

ТОВАРОВ........................................................................................... 123

1. Порядок определения стоимости реализованных товаров ................. 123

2. Документальное оформление продажи товаров со складов .............. 125

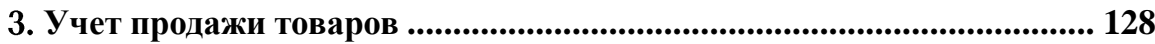

4. Учет реализации по договору комиссии .................................................... 135

5. Вопросы для самоконтроля .................................................................. 139

ЛЕКЦИЯ 9. УЧЕТ РОЗНИЧНОЙ РЕАЛИЗАЦИИ

TOBАРОВ................................................................................ 140

1. Учет реализации товаров за наличный расчет .................................... 140

2. Порядок определения валового дохода и стоимости реализованных

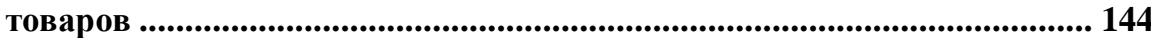

3. Учет возврата товаров покупателями ................................................... 149

4. Учет продажи товаров в кредит.............................................................. 153

5. Комиссионная продажа товаров .................................................... 157

6. Вопросы для самоконтроля......................................................................... 161

ЛЕКЦИЯ 10. УЧЕТ ПОСРЕДНИЧЕСКИХ ОПЕРАЦИЙ (АГЕНТСКИЙ ДОГОВОР) ......................................................... 163

1. Учет посреднических операций (агентский договор)............................ 163

2. Вопросы для самоконтроля ............................................................................ 168 


\section{ЛЕКЦИЯ 11. УЧЕТ ТОВАРООБМЕННЫХ}

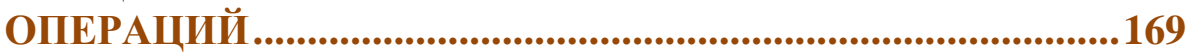

1. Сущность товарообменных операций..................................................... 169

2. Учет при передаче товара с одновременным исполнением

встречного обязательства.............................................................................. 171

3. Учет при получении товара до исполнения встречного

обязательства.......................................................................................................... 172

4. Учет при передаче товара до исполнения встречного

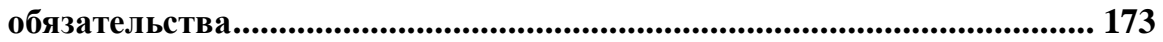

5. Вопросы для самоконтроля....................................................................... 176

КОРРЕСПОНДЕНЦИЯ СЧЕТОВ (ДЛЯ ЛЕКЦИЙ 3-11) ....177

ТЕСТОВЫЕ ЗАДАНИЯ ДЛЯ САМОКОНТРОЛЯ..................186

СПИСОК НОРМАТИВНЫХ АКТОВ И

ИСПОЛЬЗОВАННОЙ ЛИТЕРАТУРЫ ..................................198 


\section{ВВЕДЕНИЕ}

В современных условиях значительно возрастает роль бухгалтерского учета как важнейшего средства получения полной и достоверной информации об имуществе предприятия и его обязательствах и своевременного доведения этих сведений до пользователей.

Развитие рыночных отношений связано с движением товаров от производителей до их конечных потребителей, обусловленным непрерывным процессом углубления общественного разделения труда.

Операции по купле продаже товаров представляют собой основное содержание обособленной формы хозяйственной деятельности - торговли. Торговая деятельность относится к ссрере обращения, поскольку в процессе ее осуществления не происходит изменения фрорм и потребительских свойств товаров.

Торговля - вид деятельности в сфере обращения, в рамках которой осуществляются процессы по приобретению, транспортировке, частичной упаковке, расфрасовке, заготовке и реализации товаров. 


\section{Согласно \\ ПБУ \\ 5/01 \\ «Учет \\ материально-}

производственных запасов» понятие товаров для бухгалтерского учета дано в следующей интерпретации: «Товары - часть материально-производственных запасов организации, приобретенная или полученная от других юридических и фризических лиц и предназначенная для продажи и перепродажи без дополнительной обработки в производстве».

В зависимости от вида продажи, для которой предназначаются товары, торговая деятельность подразделяется на оптовую и розничную. От вида торговли, которую осуществляет предприятие, зависит специфика организации ск ладск ого и бухгалтерского учета.

В основе деятельности любого торгового предприятия лежит процесс приобретения товаров для их последующей продажи. Если приобретение товаров - начало и основа деятельности торгового предприятия, то продажа товаров - это финансово-экономическ ий смысл его существования. Разница меж ду продажной и покупной ценой проданных товаров является основным фринансовым источником жизненного цикла торгового предприятия.

Основными показателями работы торгового предприятия являются товарооборот, издержки обращения и прибыль от продаж и .

Товарооборот представляет собой общую стоимость проданных товаров. Весь товарооборот можно разделить на оптовый и розничный. Товарооборот большинства торговых предприятий является смешанным, т.е. сделки по продаже товаров совершаются ими в реж име и розничной, и оптовой торговли. 
Издержки обращения представляют собой расходы, которые несут торговые организации в процессе продвижения товаров до потребителя. Издержки участвуют в формировании финансового результата деятельности, позволяют определить качество и эффрективность работы торговой организации.

Прибыль от продажи представляет собой превышение суммы реализованных оптовых или торговый надбавок (за вычетом налогов, начисляемых за счет валового дохода от реализации) над расходами.

Вниманию преподавателей и студентов предлагается краткий курс лекций по дисциплине «Бухгалтерский учет в торговле». В данном учебном пособии рассматриваются теоретические вопросы отражения в бухгалтерском учете операций, связанных с поступлением, хранением и продажей товаров. Конечная цель изучения дисциплины обеспечивает формирование у студентов углубленных теоретических знаний и практическ их навыков в области организации и ведения бухгалтерского учета на предприятиях торговли. 


\section{ЛЕКЦИЯ 1.}

\section{ТОРГОВОЕ ПРЕДП РИЯТИЕ КАК СУБЪЕКТ РЫНОЧНОЙ ЭКОНОМ ИКИ}

\section{План лекции.}

1. Торговое предприятие как субъект рыночной экономики.

2. Вопросы для самок онтроля.

\section{1. Торговое предприятие как субъект рыночной экономики}

Торговля представляет собой отрасль народного хозяйства и вид экономической деятельности, объектом которых является купля-продажа товаров, обслуж ивание покупателей в процессе продаж и товаров и их доставк и, хранение товаров и их подготовка к продаже.

Как вид деятельности торговля выполняет ряд присущих только ей функций:

доводит товары от производителей к потребителям;

осуществляет смену фрорм стоимости (с товарной на денежную и наоборот), связывая тем самым производство и потребление; 
изучает спрос покупателей, товарное предложение производителей и поставщиков, цены на товары;

сокращает затраты времени покупателей на приобретение товаров.

Государство регулирует деятельность торговых предприятий преимущественно косвенными методами, не вмешиваясь в тек ущие хозяйственные процессы. Государственное регулирование предполагает соблюдения прав потребителей, защиту работников торгового предприятия, реализацию интересов общества, стимулирование развития торговых предприятий в требуемом направлении. Централизованно регулируются отдельные виды расходов торгового предприятия, такие как естественная убыль, командировочные расходы, расходы на рекламу и др.

На потребительском рынке торговые предприятия, реализуя товары и услуги, решают следующие задачи:

- оказывают влияние на состав товарного предложения через систему заказов, заявок промышленным предприятиям и другим поставщикам;

- изучают и удовлетворяют спрос на товары и услуги и тем самым формируют личное потребление;

- хранят товарные запасы;

- преобразуют промышленный ассортимент в торговый путем подсортировки;

- фасуют и пакуют часть товаров;

- в значительной мере влияют на устойчивость наличного денежного обращения;

- влияют на формирование бюджетной и кредитной по- 
литики на всех уровнях.

Торговые предприятия можно классифицировать по ряду признаков.

По виду деятельности выделяют два вида торговли: оптовую и розничную.

Оптовая торговля осуществляет связь между промышленностью, розничной торговлей и предприятиями общепита. Основной ее функцией является сбыт товаров крупными партиями как предприятиям розничной торговли и общепита для перепродаж и, так и промышленным предприятиям для последующей переработки.

Существование оптовых торговых предприятий обусловлено следующими факторами:

- производители предпочитают сбывать свою продукцию крупным партнерам, так как сами не имеют финансовых или материальных возможностей организовывать свою торговую или сбытовую сеть;

- эффек тивность деятельности оптовых предприятий выше, чем отдельных производственных или розничных предприятий благодаря большему размаху операций и наличию большого количества контактов с промышленными и розничными торговыми предприятиями;

- оптовые предприятия имеют материальные возможности преобразовывать промышленный ассортимент в торговый путем подсортировки продукции различных специализированных производителей товаров;

- управление товародвиж ением в рамках крупных регионов, включая формирование и использование товарных запа- 
сов, доступно только оптовым предприятиям.

В зависимости от объема сделки выделяются: оптовая торговля и мелкооптовая торговля (минимальная партия товара при последней не может быть меньше, чем количество единиц соответствующего товара в одной упаковке производителя для розничной реализации).

По характеру деятельности все оптовые предприятия подразделяются на оптовые предприятия по торговле товарами народного потребления, по продаже материальнотехнических ресурсов и средств производства, предприятия бирж евой торговли.

Основной функцией розничной торговли выступает доведение товаров до непосредственного потребителя. Розничная торговля завершает движ ение товара от производителя до потребителя. На этой стадии товар переходит из сферы обращения в сферу потребления.

Продавец, осуществляющий предпринимательскую деятельность по продаже товаров в розницу, передает покупателю товар, предназначенный для личного, семейного, домашнего или иного использования, не связанного с предпринимательск ой деятельностью.

В зависимости от особенностей торгового обслуживания покупателей, наличия торгового помещения, оборудования различают следующие виды розничной торговли: торговля через стационарную торговую сеть; торговля через передвиж ную (развозную и разносную) торговую сеть; торговля пересылкой заказанных товаров.

По форме собственности (принадлежности капитала) 
торговые предприятия можно классифицировать на государственные (муниципальные), частные и совместные.

Учредителем и, соответственно, владельцем капитала государственных торговых предприятий выступают власти различных уровней. К государственным предприятиям торговли относятся ряд предприятий розничной, в том числе ведомственной торговли, но в основном предприятия оптовой торговли.

К частным предприятиям относятся индивидуальные, семейные, коллективные предприятия. Они широко распространены в розничной торговле, но также встречаются и в оптовой торговле.

Совместными являются предприятия, учрежденные российскими и иностранными фризическими либо юридическим лицами. Такие предприятия представлены и в розничной, и в оптовой торговле преимущественно в крупных городах.

По средней численности работников торговые предприятии можно подразделить на микропредприятия, малые, средние и крупные предприятия.

На микропредприятиях численность не превышает 15 человек. К малым относятся предприятия, численность работников которых от 16 до 100 человек, к средним - от 101 до 250 человек. Если в торговом предприятии количество работников превышает 250 человек, то оно относится к категории крупHыX.

По специализации торговые предприятия можно классифицировать на: узкоспециализированные (реализующие отдельные виды товаров), специализированные (реализующие 
отдельные группы товаров или продукцию конкретных предприятий-производителей), универсальные (реализующие различные товарные группы); смешанные (реализующие как продовольственные, так и непродовольственные товары) и комбинированные (реализующие товары нескольких групп, родственных по потребительскому назначению).

По организационно-правовой форме различают коммерческие и некоммерческ ие торговые предприятия.

К оммерческие организации - это юридическими лицами, преследующие извлечение прибыли в качестве основной цели своей деятельности (создаются в форме ООО, ЗАО или ОАО). Некоммерческие организации не имеют извлечение прибыли в качестве цели своей деятельности и не распределяют полученную прибыль между участниками. К ним относят потребительские кооперативы, объединения юридических лиц (союзы и ассоциации).

\section{2. Вопросы для самоконтроля}

1.Каковы цели и задачи, решаемые торговыми предприятиями на внутреннем рынке?

2.В чем принципиальное отличие розничных предприятий от оптовых?

3.Какими факторами обособлено существование предприятий оптовой торговли?

4.Какие организационно-правовые формы и почему используются торговыми предприятиями? 


\section{ЛЕКЦИЯ 2.}

\section{ОСНОВЫ ОРГАНИЗАЦИИ БУХГАЛТЕРСКОГО УЧЕТА В ТОРГОВЫХ ПРЕДПРИЯТИЯХ}

\section{План лекции.}

1. Организация учетной работы на предприятии.

2. Учетная политика торгового предприятия.

3. Формы бухгалтерского учета, применяемые торговыми предприятиями.

4. Вопросы для самоконтроля

\section{1. Организация учетной работы на предприятии}

Для правильного руководства деятельностью торгового предприятия необходимо располагать полной, точной, объективной и своевременной информацией. Это достигается ведением бухгалтерского учета.

Основными задачами бухгалтерского учета являются:

- формирование полной и достоверной информации о деятельности организации и ее имущественном полож ении;

- обеспечение инфрормацией внутренних и внешних пользователей бухгалтерской отчетности для контроля за соблюдением законодательства Российской Федерации при осуществлении хозяйственных операций и их целесообразно- 
стью, наличием и движением имущества и обязательств, использованием материальных, трудовых и финансовых ресурсов в соответствии с утвержденными нормами, нормативами и сметами;

- предотвращение отрицательных результатов хозяйственной деятельности организации и выявление внутрихозяйственных резервов обеспечения ее финансовой устойчивости.

Задачи, стоящие перед бухгалтерским учетом в торговом предприятии, могут быть выполнены только при правильной его организации.

Организация обязана вести бухгалтерский учет в соответствии с едиными методологическими основами и правилами, установленными:

- Федеральным законом от 21.11.96 г. № 129-Ф3 «О бухгалтерском учете»;

- Положениями (стандартами) по бухгалтерскому учету (ПБУ);

- Планом счетов бухгалтерского учета финансовохозяйственной деятельности предприятий.

Грамотная постановка бухгалтерского учета в торговой организации позволяет:

- обеспечить сохранность имущества;

-обеспечить эффрективность управления ресурсами;

- исчислить финансовый результат деятельности;

- определить налоговые обязательства.

В соответствии с Законом о бухгалтерском учете руководитель торгового предприятия в зависимости от объема учет- 
ных работ может:

а) учредить бухгалтерскую службу как структурное подразделение, возглавляемое главным бухгалтером;

б) ввести в штат долж ность бухгалтера;

в) передать на договорных началах ведение бухгалтерского учета централизованной организации или бухгалтеруспециалисту;

г) вести бухгалтерский учет лично.

На практике руководитель редко ведет бухгалтерский учет лично. В этом случае он должен создать необходимые условия для его правильного ведения.

Ответственность за организацию бухгалтерского учета, соблюдение законодательства при выполнении хозяйственных операций возлагается на руководителя предприятия.

Главный бухгалтер назначается на должность и освобож дается от долж ности руководителем организации .

По российскому законодательству главный бухгалтер:

Отвечает за формирование учетной политики, ведение бухгалтерского учета, своевременное представление достоверной бухгалтерской отчетности.

Обеспечивает контроль за движением имущества и выполнением обязательств организации, соответствие законодательству осуществленных фактов хозяйственной деятельности.

Дает всем работникам организации обязательные для выполнения указания по документальному оформлению фактов хозяйственной деятельности и предоставлению для учета необходимых документов, отчетов и иных сведений. 
Бухгалтерия предприятия обеспечивает обработку документов, рациональное ведение записей в учетных регистрах, составление бухгалтерской отчетности. Структура бухгалтерии в торговом предприятии зависит от объема и сложности учетной работы. Возможно выделение следующих структурных единиц:

- по учету основных средств, нематериальных активов, материальных ценностей;

- по учету расчетов и издержек обращения;

- по учету приобретения и реализации товаров;

- по учету кассовых операций и расчетов с подотчетными лицами;

- по учету расчетов с работниками торгового предприятия;

- по учету прочих операций и составлению отчетности.

Учет начинают с документации операций. Документирование должно быть сплошным и осуществляться путем составления определенных носителей первичной учетной информации. Таким образом, каждая хозяйственная операция должна быть оформлена соответствующим первичным документом.

Для документирования хозяйственных операций торговое предприятие может:

- применять формы, содержащиеся в альбомах унифицированных форм первичной учетной документации;

- применять ведомственные формы;

- применять самостоятельно разработанные формы, содержащие соответствующие обязательные реквизиты, предусмотренные Законом о бухгалтерском учете, и обеспечиваю- 
щие достоверность отражения в учете хозяйственных операций.

К обязательным реквизитам первичных учетных документов относятся:

- наименование док умента;

- дата составления;

- наименование организации, от имени которой составлен док умент;

- содерж ание хозяйственной операции;

- измерители хозяйственной операции в натуральном и стоимостном выраж ении;

- наименование должностных лиц, ответственных за совершение хозяйственной операции и правильность ее оформления;

- личные подписи указанных лиц.

Первичные документы, по которым данные принимаются к бухгалтерскому учету, проверяются по форме (полнота и правильность их оформления) и по содержанию (законность документированных операций, логическая увязка отдельных пок азателей).

На основании документов осуществляют отраж ение операций на счетах с помощью двойной записи. Для обобщения в едином измерении данных, содержащихся в документах, используют денежную оценку; для их проверки и уточнения применяют инвентаризацию. Уточненные данные счетов используют для исчисления себестоимости путем калькуляции, а также для составления бухгалтерского баланса и других форм отчетности. 
Поскольку в основе хозяйственной деятельности торгового предприятия лежат процессы приобретения, хранения и продаж и товаров, то основными целями бухгалтерского учета в торговле являются: контроль за сохранностью товаров, своевременное представление руководству информации о товарообороте и валовом доходе, о состоянии товарных запасов и эфффективности их использования.

Для достижения этих целей решается комплекс бухгалтерск их задач:

- проверка правильности документального оформления товарных операций, своевременное и правильное отражение их в учете;

- контроль за товарными запасами, выявление неходовых, залеж алых и недоброкачественных товаров;

- контроль за фринансовыми показателя, за правильностью и своевременностью расчетов с поставщиками и покупателями, с бюджетом;

- выявление возможности для снижения издержек обращения и повышения рентабельности производства;

- контроль за наличием и движ ением материальных ценностей и денеж ных средств путем установления реж има материальной ответственности и качественного проведения инвентаризаций имущества и обязательств.

Указанные задачи бухгалтерского учета решаются как на предприятиях оптовой, так и розничной торговли. 


\section{2. Учетная политика торгового предприятия}

Организация бухгалтерского учета в торговом предприятии зависит от объема учетных работ, наличия компьютерной техники и от той учетной политики, которую ведет предприятие. Разработка и принятие учетной политики должны быть проведены не позднее 90 дней с момента государственной регистрации предприятия. Действующие предприятия должны утвердить учетную политику на очередной год до начала этого года.

Под учетной политикой организации понимается принятая ею совок упность способов ведения бухгалтерского учета первичного наблюдения, стоимостного измерения, текущей группировки и итогового обобщения фактов хозяйственной деятельности.

Каждая организация самостоятельно фрормирует свою учетную политику исходя из своей структуры и других особенностей деятельности.

На выбор учетной политики оказывают влияние факторы, зависящие от организации (величина организации, правовой статус, квалификация персонала, технологические особенности) и не зависящие от нее (налоговая, валютная политика, наличие льгот, свобода в ценообразовании).

Порядок составления учетной политики регулируется Федеральным законом «О бухгалтерском учете» от 21.11.96 г. № 129-Ф3; Положением по бухгалтерскому учету «Учетная политика организации» (ПБУ 1/2008), утвержденным приказом М инфина России от 06.10.2008 №106н. 
Каждое торговое предприятие должно в пределах установленных законодательством способов само определять методы отражения в учете закупок, транспортировки, хранения и реализации товаров, а также порядок проведения связанных с ними хозяйственных операций.

Учетная политика предприятия подлежит оформлению соответствующей организационно-распорядительной документацией (приказом и т.п.).

Выделяют три составляющие части учетной политики:

1. Методологическая часть содержит положения, которые регулируют методологию ведения бухгалтерского учета.

2. Методическая часть состоит из способов ведения бухгалтерского учета, которые описывают порядок отражения финансово-хозяйственных операций в системе бухгалтерского учета. Эти приемы не оказывают влияния на показатели отчетности, а регулируют технику отражения операций на счетах. Например, отраж ение в учете операций по приобретению товаров с использованием и без использования счета 15 никак не влияет на показатели бухгалтерской отчетности.

3. Организационная часть описывает организацию системы бухгалтерского учета: форму, по которой ведется учет, способ организации бухгалтерской служ бы, функции работников бухгалтерии и другие организационные аспекты бухгалтерского процесса.

Таким образом, методологическая часть учетной политики отвечает за то, как объекты учета будут отражаться в отчетности, методическая - за то, как эти объекты будут отражаться на счетах, а организационная - как все это будет работать. 
При этом утверждается:

- рабочий план счетов бухгалтерского учета, содержащий счета, необходимые для ведения бухгалтерского учета;

- формы первичных учетных документов, применяемых для оформления фрактов хозяйственной деятельности, по которым не предусмотрены типовые формы;

- порядок проведения инвентаризации активов и обязательств организации;

- методы оценки активов и обязательств;

- правила документооборота и технология обработки учетной информации.

Изменение учетной политики организации в соответствии с п. 16 ПБУ 1/2008 может производиться в случаях:

-изменения законодательства РФ или нормативных актов по бухгалтерскому учету;

- разработки организацией новых способов ведения бухгалтерского учета, применение которых позволит более достоверно отражать фракты хозяйственной деятельности или уменьшить трудоемк ость учетного процесса;

- существенного изменения условий деятельности (реорганизация, смена собственников и т.д.).

Формирование учетной политики осуществляется на основе следующих основных допущений:

Имущественная обособленность, т.е. на балансе предприятия учитывается только то имущество, которое согласно закону или договору ему принадлежит.

Непрерывная деятельность, т.е. организация продолжит свою деятельность в обозримом будущем, у нее нет намерения 
и необходимости ликвидации или существенного сокращения деятельности и, следовательно, обязательства будут погашаться в срок.

Последовательность применения учетной политики, т.е. выбранная организацией учетная политика осуществляется ею последовательно от одного отчетного периода к другому.

Временная определенность фактов хозяйственной деятельности организации, т.е. факты хозяйственной деятельности относятся к тому отчетному периоду, в котором они имели место, независимо от момента их оплаты и времени поступления.

Учетная политика торгового предприятия должна обеспечumь:

- полноту отражения в бухгалтерском учете всех фактов хозяйственной деятельности (требование полноты);

- большую готовность к признанию в учете расходов и обязательств, чем возможных доходов и ак тивов, не допуская создания скрытых резервов (требование осмотрительности);

- отражение в бухгалтерском учете фактов хозяйственной деятельности исходя не только из их правовой формы, но и из экономического содержания фактов и условий хозяйствования (требование приоритета содержания перед формой);

- тождество данных аналитического учета оборотам и остаткам по счетам синтетического учета на первое число каждого месяца, а также тождество показателей бухгалтерской отчетности данным синтетического и аналитического учета (требование непротиворечивости); 
- своевременное отражение фрактов хозяйственной деятельности в учете и отчетности (требование своевременности);

- рациональное и экономное ведение бухгалтерского учета, исходя из условий хозяйственной деятельности и величины предприятия (требование рациональности).

На основе Типового плана счетов каждой торговой организацией составляется рабочий план счетов. Рабочий план счетов представляет собой перечень синтетических счетов бухгалтерского учета в последовательности, предусмотренной типовым планом. Выбранная группировка счетов должна обеспечить учет всех хозяйственных операций, осуществляемых в процессе деятельности торгового предприятия.

В рабочие планы счетов предприятий в зависимости от осуществляемых ими видов деятельности и производственной структуры включаются определенные типы специфических счетов. В отличие от промышленности содержание учета в торговле определяют в основном операции по обороту товаров, а также связанные с этим доходы и расходы.

Учет этих специфических операций осуществляется с помощью следующей группы счетов: 41 «Товары», 42 «Торговая наценка», 44 «Расходы на продажу», 45 «Товары отгруженные», 90 «Продажи», 60 «Расчеты с поставщиками и подрядчиками , 62 «Расчеты с покупателями и заказчиками », - некоторые из которых в промышленном учете применяются редко. Однако, в торговле, где не осуществляется сам процесс производства, в свою очередь, не используют ряд других счетов, в частности, счета 20 «Основное производство», 25 «Общепроизводственные расходы», 26 «Общехозяйственные рас- 
ходы», 40 «Выпуск продукции (работ, услуг)», 43 «Готовая продукция».

Счет 41/1 «Товары на складах» используется для учета товаров на складах оптовой организации, а также на складах и кладовых предприятий общественного питания. В розничных торговых организациях он применяется крайне редко для учета товаров на централизованных распределительных складах. Счет 41/2 «Товары в розничной торговле» применяется для учета товаров, находящихся в розничной торговой сети (универмаги, магазины, ларьки), которая включает также мелкооптовые базы магазины, выделенные для продажи товаров учреж дениям, организациям и предприятиям. Счет 44 «Расходы на продаж у» предназначен для учета расходов, связанных с реализацией товаров. счет 45 «Товары отгруженные» применяется только в оптовом звене торговли. Счет 62 «Расчеты с покупателями и заказчиками» более широко применяется в розничной торговле (операции по продаже товаров мелким оптом при безналичной форме расчетов). Из пассивных счетов для торговли специфичен лишь счет 42 «Торговая наценка». Отраженные по счету 42 суммы показывают объем валового дохода (полученного в виде наценки к покупной цене товара) торгового предприятия, который по мере реализации товара преобразуется в прибыль текущего года.

Рабочий план счетов должен быть логическим продолжением форм бухгалтерской отчетности. Поскольку между балансом и планом счетов существует тесная взаимосвязь, данные баланса должны по возможности непосредственно вытекать из строк оборотно-сальдового баланса или Главной книги. 
То же самое относится к Отчету о прибылях и убытках. Следовательно, при разработке рабочего плана счетов необходимо стремиться к исключению любых перегруппировок бухгалтерских данных, отраж енных на счетах, которые могут происходить при подготовке бухгалтерск ой отчетности.

К роме того, во избеж ание разрастания регистров, услож нения их восприятия и пользования, при разработке рабочего плана счета и субсчета имеет смысл выделять только для той инфрормации, которая действительно обладает существенным значением для организации.

Торговые организации в соответствии с главой 25 «Налог на прибыль организаций» Налогового кодекса обязаны также сформировать учетную политику для целей налогообложения. При этом, чтобы минимизировать свои затраты организации должны стремиться к сближению положений учетной политики в целях бухгалтерского и учетной политики в целях налогообложения.

При желании бухгалтерский и налоговый учет могут быть полностью интегрированы, за исключением расхождений в определении стоимости активов (основных средств, нма, товаров), учет которых представляет собой наиболее сложную методологическую проблему. Степень несоответствия бухгалтерских и налоговых данных тем выше, чем шире спектр хозяйственных операций, происходящих в организации.

Унификация возможна в отношении следующих способов ведения бухучета и определения налоговых обязательств организации:

- метода признания доходов и расходов; 
- способа начисления амортизации по основным средствам;

- определения срока полезного использования основных средств;

- установления лимита стоимости основных средств, в пределах которого их стоимость единовременно списывается на расходы;

- способа начисления амортизации по НMA;

- способа определения стоимости реализованных товаров;

- порядка создания резервов.

\section{3. Формы бухгалтерск ого учета,} применяемые торговыми предприятиями

Форма бухгалтерского учета - это комплекс взаимосвязанных учетных регистров в совокупности с правилами их использования с целью отражения хозяйственных операций и получения итоговых данных.

Каждая форма бухгалтерского учета определяет конкретные способы:

- регистрации хозяйственных явлений;

- группировки однородных данных;

- разноски по синтетическ им и аналитическ им счетам;

- подсчета оборотов и конечных сальдо счетов для контроля данных и составления отчетности.

Организации самостоятельно выбирают форму бухгалтерского учета: применяемые регистры, их построение, после- 
довательность и способы записи в них. Конкретное решение зависит от размеров организации, ее структуры, специфики деятельности, уровня технической и компьютерной оснащенности. При выборе формы учета торговыми предприятиями главная роль принадлежит объему перерабатываемой информации.

В настоящее время на предприятиях применяются следующие формы бухгалтерского учета: мемориально-ордерная; ж урнально-ордерная; таблично-автоматизированная.

Признаками, отличающими одну фрорму учета от другой, являются:

- назначение, содержание и внешний вид применяемых учетных регистров синтетического и аналитического учета;

- взаимосвязь хронологическ их и систематических регистров синтетического и аналитического учета;

- последовательность и способы записей в учетные регистры;

- степень компьютеризации.

На рис. 2.1 показана совокупность учетных регистров, применяемых при мемориально-ордерной фрорме учета и последовательность их офрормления.

Разновидностью мемориально-ордерной фрормы является форма «Ж урнал-Главная». Она рассчитана на организации, в практике ведения учета которых используются $20-25$ синтетических счетов. При этой форме на основании документов или накопительных ведомостей также составляются мемориальные ордера. 


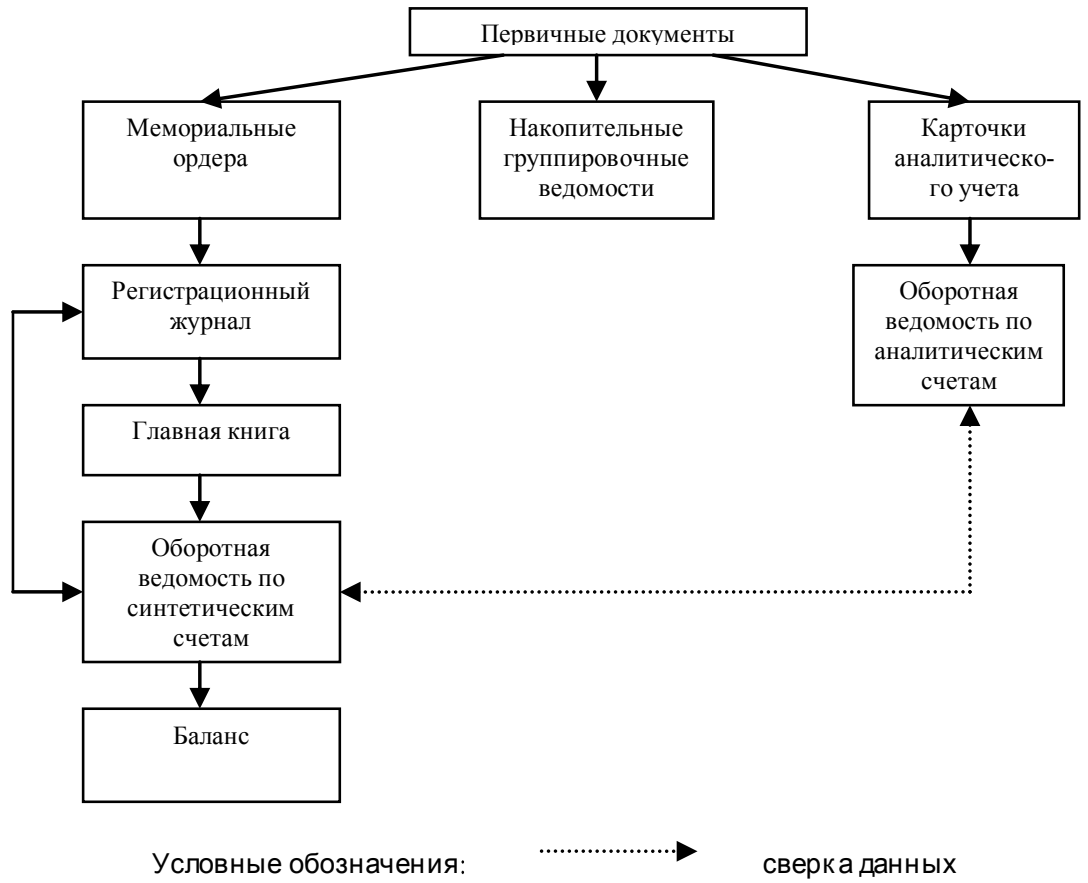

\section{Рисунок 2.1 - Мемориально-ордерная форма учепя}

Главное ее отличие от мемориально-ордерной формы заключается в составлении комбинированного регистра «Ж урнал - Главная книга». В нем хронологическая регистрация мемориальных ордеров совмещена с систематической записью по синтетическим счетам. Он содержит остатки на начало месяца по всем синтетическим счетам, в конце месяца подсчитываются обороты по дебету и кредиту каждого счета и выводятся остатки на конец месяца. Наличие этих данных позволяет не составлять оборотную ведомость по синтетическ им счетам.

На рис. 2.2 представлена ж урнально-ордерная форма счетоводства. 


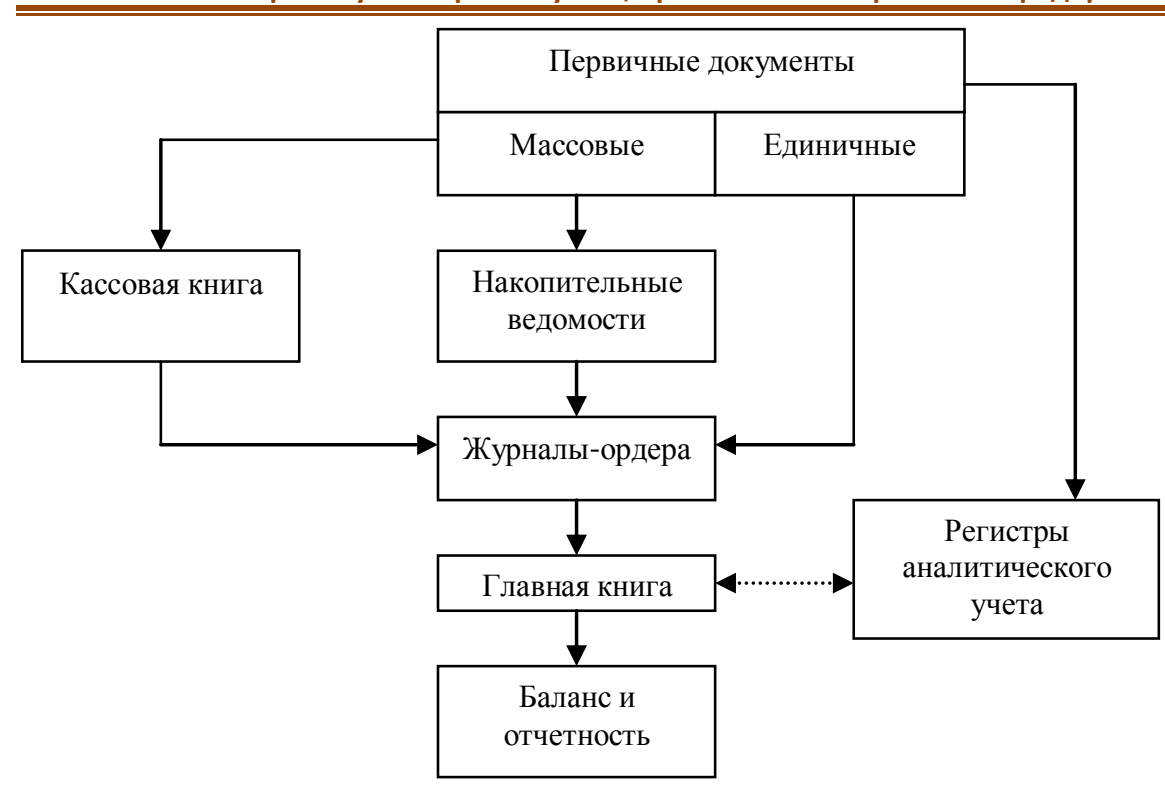

\section{Рисунок 2.2 - Ж урнально-ордерная форма бухгалперского учепа}

Большинство торговых предприятий являются субъектами малого бизнеса. В хозяйствующих субъектах, имеющих статус малого предприятия, нашли применение упрощенные формы бухгалтерского учета, предусмотренные Типовыми рекомендациями по организации бухгалтерского учета дпя субъектов малого предпринимательства, утв. Приказом М инфина России от 21.12.98 г. № $64 \mathrm{H}$.

В настоящее время распространение получили две: простая форма и форма учета с использованием регистров дпя учета имущества. Малые предприятия, занятые торговлей и иной посреднической деятельностью, могут использовать регистры из упрощенной фрормы бухгалтерского учета, при 
необходимости применяя отдельные регистры для учета определенных ценностей, преобладающих в их деятельности (товарно-материальных запасов, финансовых активов и т.п.), из ж урнально-ордерной формы счетоводства.

Простая форма применяется при следующих условиях: отсутствии собственных основных средств; расчетах с поставщиками и покупателями по факту совершения операций; учете доходов и расходов на основе полученных и уплаченных денежных средств.

При этой форме на основе данных первичных учетных документов ведется комбинированный регистр синтетического и аналитического учета - К нига хозяйственных операций по форме № К -1. книга содерж ит все применяемые малым предприятием счета и позволяет вести учет хозяйственных операций на каждом из них. В течение года в хронологическом порядке линейно-позиционным способом фриксируется движение имущества, источников и затрат по всем счетам способом двойной записи.

Форма учета с использованием регистров бухучета имущества (ведомости ф. № B-1 - B-9) применяется малыми предприятиями, имеющими собственные основные средства, производственные запасы и осуществляющими расчеты с покупателями и поставщиками на основе предварительной или последующей оплаты счетов. 


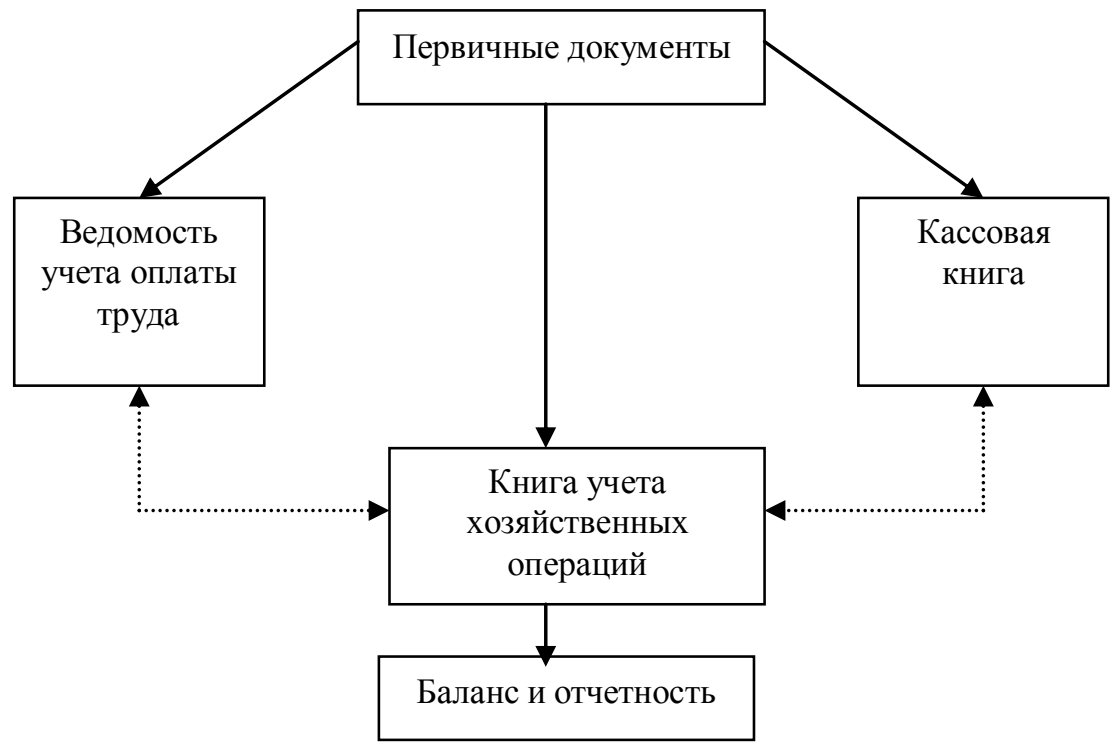

\section{Рисунок 2.3 - Проспая форма бухгалперск ого учепя}

Учетными регистрами являются: Ведомость учета основных средств, начисленных амортизационных отчислений (Ф. № В-1); Ведомость учета производственных запасов и товаров, а также НДС, уплаченного по ценностям (Ф. № В-2); Ведомость учета затрат на производство (Ф. № В-3); Ведомость учета денежных средств и фондов (Ф. № В-4); Ведомость учета расчетов и прочих операций (Ф. № В-5); Ведомость учета продаж и (Ф. № В-6 - оплата); Ведомость учета расчетов с поставщиками (Ф. № В-7); Ведомость учета оплаты труда (Ф. № В-8). 


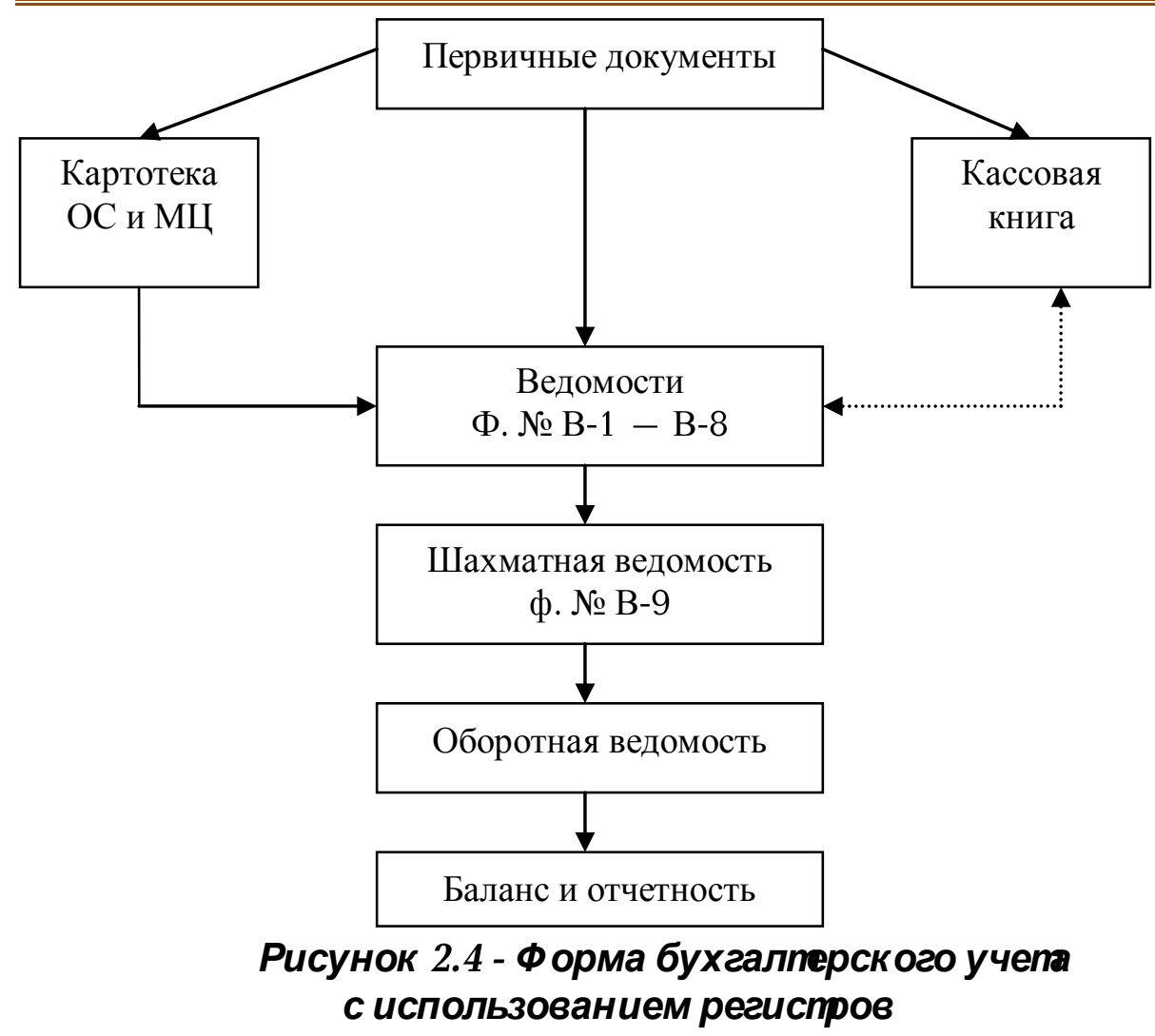

Таблично автоматизированная форма учета ведется с использованием компьютерной техники. С помощью специальных программ данные первичных документов группируются и обобщаются непосредственно на компьютере, в результате чего пользователь получает информацию, эквивалентную по содерж анию регистрам синтетического и аналитического учета. 


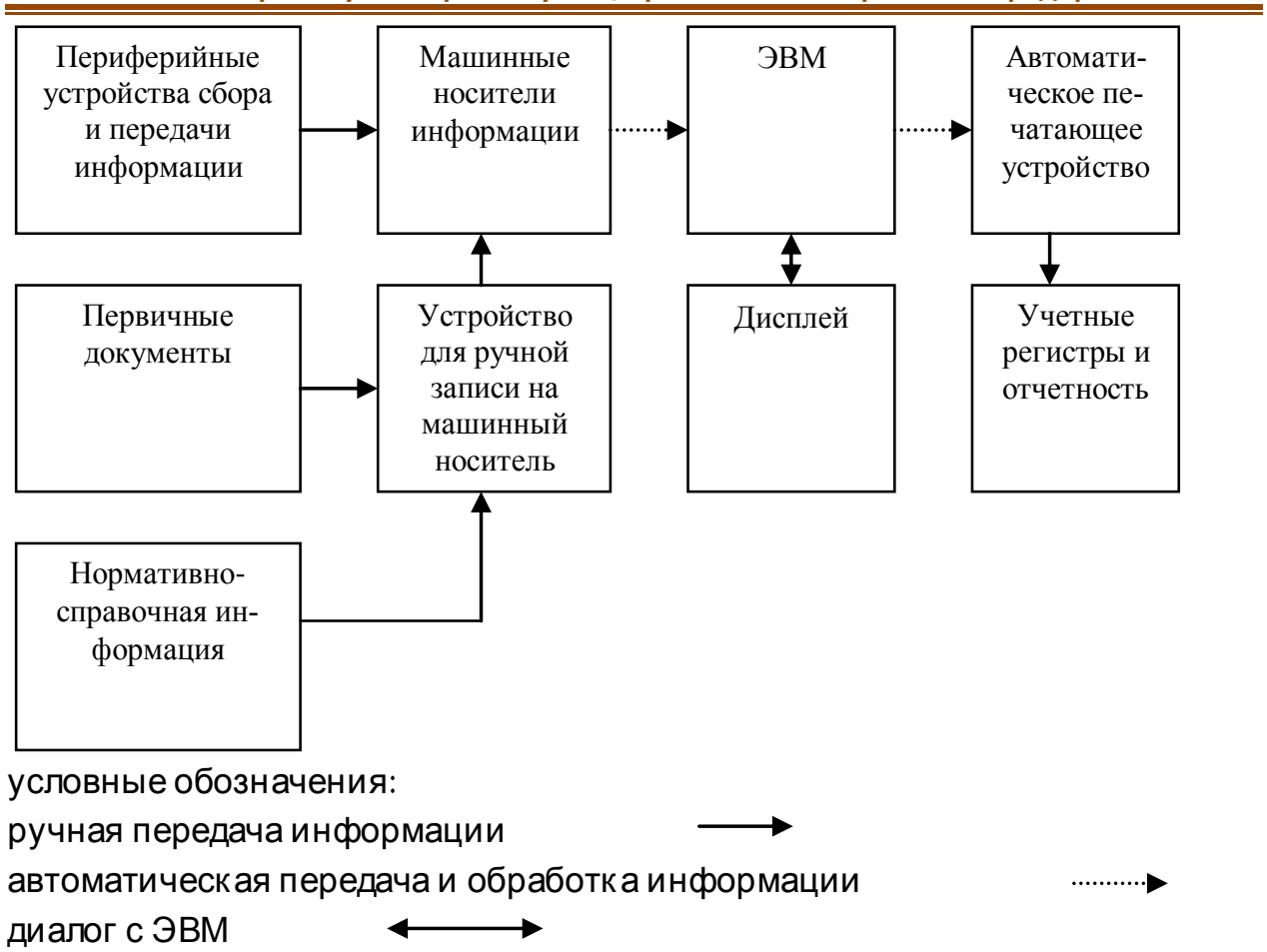

\section{Рисунок 2.5 - Таблично-авпоматизированная форма бух- галперск ого учепа}

Торговое предприятие в зависимости от принятой организацией фрормы бухгалтерского учета учет товаров мож ет веСТИ:

- в журналах-ордерах №10, 10/1 и ведомости №10-а - при применении ж урнально-ордерной фрормы счетоводства;

- в ведомости учета производственных запасов и товаров, а также НДС, уплаченного по ценностям, № В-2 - при применении упрощенной фрормы бухгалтерского учета с использованием регистров; 
- в Книге учета фактов хозяйственной деятельности № K 1 - при применении простой фрормы бухгалтерского учета.

\section{4. Вопросы для самоконтроля}

1. Как может быть организован учет в торговом предприятии?

2. М есто главного бухгалтера в служ ебной иерархии.

3. порядок формирования учетной политики торговым предприятием.

4. Как торговая организация формирует рабочий план счетов?

5. Какие требования предъявляет Минфин РФ к учетной политике предприятия?

6. Какие формы бухгалтерского учета могут применяться торговыми организациями, имеющими статус малого предприятия?

7. Каковы принципиальные отличия автоматизированной системы учета от других форм счетоводства? 


\title{
ЛЕКЦИЯ 3.
}

\section{УЧЕТ ПОСТУПЛЕНИЯ ТОВАРОВ}

\author{
План лекции.
}

1. Документальное оформление поступления товаров.

2. Учет операций по приобретению товаров.

3. Аналитический учет товаров.

4. Вопросы для самоконтроля.

\section{1. Докуменпльное оформление поспупления поваров}

В основе деятельности любого торгового предприятия лежит процесс приобретения товаров для их последующей продажи. движение товара от поставщика к потребителю оформляется товаросопроводительными документами, предусмотренными условиями договора поставки товаров и правилами перевозки грузов (товарной накладной, товарнотранспортной накладной и другими). Если товар поступил в торговое предприятие без сопроводительных документов или с их частичным отсутствием, то он принимается комиссией и оформляется приемным актом.

Товарная накладная (ф. № ТОРГ-12) в торговом предприятии может выступать как приходным, так и расходным товарным документом. Она выписывается материально ответственным лицом при офрормлении отпуска товаров со склада, а 
также при принятии товаров на ск лад. в нак ладной указывается номер и дата составления, наименования поставщика и покупателя, наименование и кратк ое описание товара, его количество и цена, общая сумма поставк и с учетом НДС. Товарная нак ладная подписывается материально ответственными лицами, сдавшими и принявшими товар, заверяется круглыми печатями организаций поставщика и получателя. Один экземпляр товарной накладной передается принимающей организации, у которой является основанием для оприходования этих ценностей, остальные остаются в организации, продавшей товары, и являются основанием для их списания.

Товарно-транспортная накладная (ф. № 1-Т) выписывается при доставке товаров автомобильным транспортом. Она состоит из двух разделов: товарного и транспортного. К товарнотранспортной накладной в зависимости от специфики товаров могут прилагаться и другие документы, следующие с грузом. Товарный раздел определяет взаимоотношения грузоотправителя и грузополучателя и служит основанием для списания товарно-материальных ценностей у грузоотправителя и оприходования их у грузополучателя. Транспортный раздел определяет взаимоотношения заказчиков автотранспорта с организациями - владельцами автотранспорта, выполняющими перевозку грузов, и служит для учета работы транспорта и расчетов за оказанные услуги по перевозке грузов.

Если материально ответственное лицо организациипокупателя получает товары вне своего склада, то ему выписывается доверенность (фр. № M -2 или М -2a), подтверждающая 
право материально ответственного лица на получение товара. Доверенность долж на содерж ать такие показатели, как : номер и дату выдачи, срок действия, наименования и адреса плательщика и поставщика, номер и дату документа, являющегося основанием для отпуска товаров, наименование и краткое описание товаров, подлеж ащих получению.

В случае несоответствия фрактического наличия товаров или отклонения по качеству, установленному в договоре, или данным указанным в сопроводительных документах, составляется акт об установленном расхождении по количеству и качеству при приемке товарно-материальных ценностей (ф). № ТОРГ-2), являющийся основанием для предъявления претензий поставщику. Акт составляется комиссией, в состав которой должны входить материально ответственные лица торговой организации и представитель поставщика. Возможно составление акта в одностороннем порядке при согласии поставщик а или его отсутствии. В сопроводительных документах делается отметка о составлении акта.

Если поступают импортные товары, то на товарноматериальные ценности, по которым установлены расхождения между данными поставщика и фактическим количеством или качеством, в пяти экземплярах составляется акт об установленном расхождении по количеству и качеству при приемке импортных товаров (ф. № ТОРГ-3). Данный акт является основанием для направления претензионного письма поставщику или транспортной организации.

Возврат товара поставщику при обнаружении брака в 
процессе реализации товара, при несоответствии товара стандартам или согласованному образцу по качеству, некомплектности товаров осуществляется путем оформления расходной нак ладной. При этом, условия возврата товаров поставщику долж ны быть оговорены договором поставк и.

Учет первичных документов по приходу товаров материально ответственным лицам рекомендуется вести в Ж урнале поступления товаров, который должен содержать название приходного документа, его дату и номер, дату регистрации документа, сведения о поступивших товарах.

Оформленные документы на приемку товаров являются основанием для расчетов с поставщиками, и их данные не могут быть пересмотрены после приемки товаров в организации (за иск лючением потерь товаров от естественной убыли и боя при транспортировке).

Поступающие товары приходуются в день окончания их приемки по фрактическому количеству и сумме. Первичные учетные документы по движению товаров на складах организации должны быть сданы в установленные сроки в бухгалтерию для их проверки с точки зрения правильности офрормления и зак онности совершенных операций.

При совершении операций по реализации товаров поставщик составляет счета-фактуры по налогу на добавленную стоимость. При отгрузке товаров, не облагаемых НДС, в счетефак туре сумма налога не указывается и делается запись «Без налога (НДС)». У покупателя счета-фрактуры регистрируются в книге покупок и служат основанием для принятия предъявленных сумм налога к вычету или возмещению из бюджета. 


\section{2. Учет операций по приобретению товаров}

Основными документами по регулированию бухгалтерского учета товаров являются:

- Положение по бухгалтерскому учету «Учет материально-производственных запасов» ПБУ 5/01, утвержденное приказом М инфрина России от 09.06.2001 г. № 44н;

- Методические указания по бухгалтерскому учету материально-производственных запасов, утвержденные приказом М инфина России от 28.12.2001 г. №119н.

Согласно п. 5 ПБУ 5/01 товары принимаются к бухгалтерскому учету по фак тическ ой себестоимости.

Фак тической себестоимостью товаров, приобретенных за плату, признается сумма фактических затрат организации на их приобретение за исключением НДС и иных возмещаемых налогов.

Фактическая себестоимость товаров, приобретенных за плату, вк лючает:

- установленную договором стоимость товаров;

- расходы по заготовке и доставке приобретаемых товаров, производимые до момента их передачи в продажу и не вк люченные в цену товара по договору с поставщиками;

- тамож енные пошлины;

- невозмещаемые налоги, уплачиваемые в связи с их приобретением;

- суммы, уплачиваемые организациями за информацион- 
ные и консультационные услуги, связанные с приобретением товаров;

- вознаграждения, уплачиваемые посреднической организации, через которую приобретены товары;

- расходы по предпродаж ной подготовке.

Транспортно-заготовительные расходы (ТЗР) - это затраты организации, непосредственно связанные с процессом заготовления и доставки товаров в организацию.

В состав транспортно-заготовительных расходов входят:

- расходы по погрузке товаров в транспортные средства и их транспортировке, подлежащие оплате транспортной организации или поставщику сверх установленной договором стоимости товаров;

- расходы по содержанию заготовительно-складского аппарата организации (например, зарплата работников, занятых зак упкой и доставкой товаров);

- плата за хранение товаров в местах приобретения, на ж елезнодорожных станциях, портах, пристанях;

- расходы по страхованию груза во время перевозки;

- проценты по привлеченным для приобретения товаров кредитам и займам, если они начислены до принятия этих товаров к бухгалтерскому учету;

- расходы по командировкам, непосредственно связанным с закупкой товаров и их сопровож дением в организацию;

- стоимость потерь товаров в пути (порча, недостача) в пределах норм естественной убыли.

Расходы по заготовке и доставке товаров до складов орга- 
низации, производимые до момента передачи этих товаров, могут либо включаться в фактическ ую себестоимость товаров, либо относиться к расходам на продажу. Применение того или иного варианта закрепляется в учетной политике торгового предприятия.

Порядок транспортировки товаров определяется условиями купли продажи. расходы по доставке товаров от поставщика до ск лада покупателя мож ет нести либо поставщик, либо покупатель, либо расходы распределяются между ними.

Товары отражаются в учете на счете 41 «Товары». Формирование фактической себестоимости и оприходование товаров на счете 41 «Товары» мож ет отраж аться:

- путем непосредственного (прямого) включения расходов в фрактическую себестоимость товаров (присоединение к договорной цене товаров);

- путем отнесения покупной стоимости товаров и расходов, включаемых в их фактическ ую себестоимость, на отдельный счет 15 «Заготовление и приобретение материальных ценностей», или на отдельный субсчет к счету 41 «Товары».

К онкретный вариант учета расходов, включаемых в фак тическую себестоимость товаров, устанавливается организацией самостоятельно и закрепляется в учетной политике. При этом необходимо учитывать, что счет 15 «Заготовление и приобретение материальных ценностей» целесообразно использовать в следующих случаях:

- при учете товаров по учетным ценам. Применение учетных цен позволяет не только установить контроль за сто- 
имостью товаров, но и решить методическую проблему, возникающую в ситуациях, когда со склада осуществляется отпуск товаров, фрактическая стоимость поступления которых еще до конца не сформирована. Например, курсовые разницы можно включить в стоимость товаров только после их оплаты. Однако момент реализации этих товаров может предшествовать дате их оплаты;

- при сложной структуре себестоимости товаров. В отдельных случаях их себестоимость может иметь сложную структуру: закупочная стоимость, фррахт, страховка, доведение до состояния, пригодного к использованию и т. д. При этом отдельные виды расходов сложно будет отнести напрямую на стоимость конкретных товарных запасов. В этом случае применение счета 15 удобно, так как на нем легко выделить информацию только о тех товарах, которые были поставлены в отчетном периоде;

- при длительности процесса заготовления товаров. Если процесс заготовления товарных запасов занимает продолж ительное время, например поставка из-за границы, тогда применение счета 15 удобно тем, что позволяет разделить товары, находящиеся на ск ладе организации (числятся на счете 41), и товары, находящиеся в пути или в стадии приготовления к использованию.

Иногда возникает необходимость учета товаров по учетным (плановым) ценам: если необходимо оформлять поступление и отпуск товаров в течение всего периода, рассчитать их фактическую себестоимость станет возможным лишь по 
окончании этого периода (месяца), а также в случае неотфак турованных поставок .

Неотфактурованными считаются поставки, при которых на товары, поступившие в организацию, отсутствуют товаросопроводительные или расчетные документы. В случае таких поставок товары приходуются и учитываются по принятым в организации учетным ценам, а после получения расчетных документов их учетная цена корректируется и одновременно уточняются расчеты с поставщиком.

При учете товаров по учетным ценам разница между стоимостью по этим ценам и фактической себестоимостью отражается на счете 16 «Отклонение в стоимости материальных ценностей». Накопленные на этом счете суммы списываются в дебет счета 44 «Расходы на продажу» пропорционально стоимости отпущенных товаров по учетным ценам. Если возникла отрицательная разница, то она списывается методом красного сторно.

Для учета поступления товаров на предприятиях розничной торговли используется счет 41 «Товары» субсчет 2 «Товары в розничной торговле», субсчет 3 «Тара под товаром и порожняя». Организации оптовой торговли используют счеm 41 «Товары» субсчет 1 «Товары на складах».

Счет 41 является активным, дебетовый оборот показывает общую стоимость товаров, поступивших в торговое предприятие, кредитовый оборот - выбытие товаров, сальдо - остаток товаров на конец отчетного периода.

Hа счеme 41 субсчет 1 «Товары на складах» учитывают 
наличие и движение товарных запасов, находящихся на оптовых базах, складах, в кладовых предприятий общественного питания, овощехранилищах, холодильниках и т.п.

На cчеme 41 субсчеm 2 «Товары в розничной торговле» учитывают наличие и движение товаров, находящихся на предприятиях розничной торговли (в магазинах, палатках, киосках и т.п.) и в буфетах предприятий общественного питания. На этом же субсчете учитывают наличие и движ ение стеклянной посуды (банок, бутылок и др.).

На счете 41 субсчет 3 «Тара под товаром и порожняя» учитывают наличие и движение тары под товарами и тары порожней (кроме стеклянной посуды на предприятиях розничной торговли и в буфетах общепита). Тара мож ет учитываться по средним учетным ценам, которые устанавливают на предприятии по группам (видам) тары применительно к составу и ценам на нее.

К счету 41 может быть также открыт субсчет 4 «Покупные изделия», предназначенный для учета товаров купленных для немедленной продажи.

Товары, не являющиеся собственностью торгового предприятия, но находящиеся на его территории, учитываются на забалансовых счетах в зависимости от условий, на которых они приняты предприятием (002 «ТМЦ, принятые на ответственное хранение», 004 «Товары, принятые на комиссию»).

НДС по поступившим товарам учитывается на счете 19 «НДС по приобретенным ценностям» субсчет 3 «НДС по приобретенным материально-производственным запасам». Осно- 
ванием для отражения на счете 19 сумм НДС, относящихся к полученным от поставщиков товарам, является выделение данных сумм в первичных учетных документах (накладных, счетах-фрак турах и других).

При отнесении указанных сумм налога к возмещению из бюдж ета эти суммы списываются с кредита счета 19 «НД по приобретенным ценностям» субсчет 3 «НДС по приобретенным материально-производственным запасам» в дебет счета 68 «Расчеты по налогам и сборам» субсчет «Расчеты по НДС».

В оптовые организации товары поступают от промышленных предприятий, от посреднических, заготовительных организаций, зарубеж ных фирм и т.д.

В розничную торговлю товары для продаж и поступают от производственных предприятий, оптовых организаций, от фирм, ведущих внешнюю торговлю, со складов и т.д.

В розничной торговле товары могут учитываться по покупным или продажным ценам. Если учет ведется по продажным ценам, то разница между покупными и продажными ценами отражается на счете 42 «Торговая наценка». Выбранный вариант учета зак репляется в учетной политике организации.

Учет товаров по покупным ценам ведут при узком ассортиментном наборе и изменении цен приобретения не чаще одного раза в месяц. Учет товаров по продажным ценам, как правило, применяется в том случае, если организация розничной торговли имеет большой ассортимент товаров и не имеет возможности вести количественный учет реализованных товаров по каждому наименованию с конкретными покупными 
ценами.

При поступлении товара от поставщиков (юридических лиц) делается проводка:

Дm 41/1 «Товары на складах» или 41/2 «Товары в розничной торговле» - на стоимость товара

Дт 41/3 «Тара под товаром и порожняя» - на стоимость тары

Дт 19 «НДС по приобретенным ченностям» - на сумму НДС

Кm 60 «Расчеты с поставщиками и подрядчиками .

Величина торговой надбавки при этом отражается запиСЬЮ:

Дm 41/2 «Товары в розничной торговле» - Кm 42 «Торговая наценка».

В розничной торговле стеклянная посуда учитывается вместе с товарами на счете 41/2 «Товары в розничной торговле». При этом, если одновременно с товаром предприятие получает тару и возвращает ее поставщику, то на товарнотранспортной нак ладной указывается «возврат тары» и сумма. На эту сумму производится зачет расчетов с поставщиком по таре:

Дm 60 «Расчеты с поставщиками и подрядчиками» - К 41/2 «Товары в розничной торговле».

Bce транспортные расходы, возникающие в процессе приобретения товаров, относятся к расходам на продажу, при этом НДС, включенный в счета за оказанные транспортные услуги, отражается на счете 19 «НДС по приобретенным цен- 
НостяМ».

Дm 44 «Расходы на продажу» - на сумму транспортных расходов

Дm 19 «НДС по приобретенным ценностям» - на сумму НДС

Кm 60 «Расчеты с поставщиками и подрядчиками» - на всю начисленную сумму.

Погашение задолженности перед поставщиком за полученные товары, а также перечисление авансов и предоплаты оформляется так :

Дm 60 «Расчеты с поставщиками и подрядчиками» - на сумму оплаченной задолженности поставщикам

Кm 51 «Расчетные счета» - на сумму, оплаченную с расчетного счета

Кm 52 «Валютные счета» - на сумму, оплаченную с валютного счета

Кm 50 «Касса» - на сумму, оплаченную наличными

Km 55 «Специальные счета в банках», с/сч «Аккредитивы» - на сумму оплаченную с аккредитива

Кm 60 «Расчеты с поставщиками и подрядчиками», с/сч «Векселя выданные» - на сумму оплаченную векселем

Кm 66 «Расчеты по краткосрочным кредитам и займам», 67 «Расчеты по доләосрочным кредитам и займам» - на сумму, оплаченную за счет кредита.

После оплаты оприходованных ценностей возможно учесть сумму НДС при расчетах с бюдж етом:

Дm 68 «Расчеты по налогам и сборам» - Кm 19 «НДС по 
приобретенным ценностям»

Если после предоплаты была отменена поставка товара, то на сумму возврата средств производится запись:

Дт 51 «Расчетные счета», 52 «Валютные счета», 50 «Касса»- Km 60 «Расчеты с поставщиками и подрядчиками»

Предъявленные поставщику или транспортной организации претензии по недостаче или порче товаров отраж аются на счете 76 «Расчеты с разными дебиторами и кредиторами» субсчет 2 «Расчеты по претензиям» записью:

Дm 76/2 «Расчеты по претензиям»- Km 60 «Расчеты с поставщиками и подрядчиками».

Аналогично учитываются претензии к поставщикам на суммы излишней оплаты, произведенные в связи с несоответствием цен, указанных в расчетных документах, и цен, предусмотренных в договоре, в результате арифметическ их ошибок, допущенных в расчетных док ументах поставщика, и по другим подобным причинам.

Если к моменту обнаружения недостачи, порчи или завышения цен в расчетных документах поставщика, расчеты не были произведены, то оплата производится за вычетом стоимости недостающих и испорченных по вине поставщика товаров. В этом случае не оплаченные суммы на счете 76/2 «Расчеты по претензиям» не отраж аются.

При отсутствии оснований для предъявления претензии или иска, а также если иск покупателя к поставщику или транспортной организации судом не удовлетворен, суммы недостач и потерь списываются записями: 
Дm 94 «Недостачи и потери от порчи ценностей» - Кm 76/2 «Расчеты по претензиям»

Дт 91 «Прочие доходы и расходы» - Кm 94 «Недостачи и потери от порчи ценностей»

Товары могут поступать и от подотчетных лиц торговой организации. Они закупают товары на рынке за наличные и оформляют акт закупки. Оприходование товаров в таком случае отраж ают:

Дm 41/2 «Товары в розничной торговле» - Кm 71 «Расчеты с подотчетными лицами»

Дm 41/2 «Товары в розничной торговле»- Кm 42 «Торговая наценка»

В случае приобретения товаров у физическ ого лица, зарегистрированного как предприниматель без образования юридическ ого лица (ПБЮЛ) делают запись:

Дm 41/2 «Товары в розничной торговле» - Кm 76 «Расчеты с разными дебиторами и кредиторами», с/сч «Расчеты с ПБЮЛ»

Учет поступления товаров также может вестись с использованием счета 15 «Заготовление и приобретение материальных ценностей».

При этом в течение месяца в дебет счета 15 относится покупная стоимость товаров, а также затраты по приобретению товаров (без НДС). Записи производятся в корреспонденции со счетами 60, 71, 76 и т.п. в зависимости от того, откуда поступили те или иные ценности.

В кредит счета 15 в корреспонденции со счетом 41 отно- 
сится учетная стоимость товаров.

В конце месяца сумма разницы в стоимости приобретенных товаров, исчисленная меж ду их фактической себестоимостью (Доб счета 15) и учетной стоимостью (Коб счета 15), списывается на счет 41.

Отклонения в стоимости товаров, учтенные на счете 41, подлежат последующему списанию на счеm 90/2 «Ceбестоимость продаж» в полной сумме или распределяются между проданными товарами и остатком товаров по среднему проценту.

Остаток по счету 15 на конец месяца показывает наличие товаров в пути.

\section{3. Аналитический учет товаров}

В организациях торговли аналитический учет товаров ведется по каж дому материально ответственному лицу по ассортименту товаров в оптимальном разрезе.

В зависимости от специфики деятельности предприятия применяется один из трех вариантов учета товаров:

- по предметный - заключается в учете движения каждой единицы товара. Применяется, как правило, в комиссионной торговле, так как расчеты с комитентом ведутся за каждую вещь в отдельности;

- натурально-стоимостной - учет движения товаров фик сируется по каждому наименованию в натуральном и стоимостном выражении. Применяется в оптовой торговле, для 
учета товаров на ск ладах, оптово-розничных базах и подобных структурах с ограниченной номенклатурой, но большими объемами;

- стоимостной - заключается в учете общего объема товарной массы в денежном выражении с обязательным наличием материально ответственных лиц, ведущих товарные отчеты. Используется в розничной торговле, так как при реализации за наличный расчет в кассовом чеке отражается только стоимость реализованных товаров.

Ск ладск ой учет товаров ведет материально ответственное лицо разными методами в зависимости от способа хранения товаров: партионным или сортовым. Складск ой учет ведется в натуральном измерении на основании приходных и расходных товарных док ументов.

Аналитический учет товаров бухгалтерией ведется в натурально-стоимостном выражении, т.е. по наименованиям товаров с их отличительными признаками (сорт, марка и.т.п.), по количеству и фак тическ ой себестоимости.

При партионном способе хранения на складе каждая вновь поступающая партия товаров по одному транспортному документу хранится отдельно от ранее поступивших товаров. этим обеспечивается отдельный учет поступающих товаров одного наименования с разной фак тическ ой себестоимостью.

Одной партией допускается считать:

- товары, поступившие одним видом транспорта, независимо от количества транспортных док ументов;

- товары одного наименования, поступившие одновре- 
менно по нескольким транспортным документам от одного поставщика.

Партионный способ следует одновременно применять и на ск ладах и в бухгалтерск ой служ бе.

При данном способе аналитическ ий учет товаров ведется с использованием специальных партионных карт (ф. № $\mathrm{MX}$ 10), в которых учитывается поступление товаров данной партии и расход товаров из данной партии. На каждую поступившую партию товаров материально ответственное лицо выписывает партионную карту в двух эк земплярах, где указывается номер и дата ее составления, номер и дата накладной, по которой товар поступил, наименование, артикул, сорт и количество товаров. один экземпляр карты остается на складе и служит регистром складск ого учета, другой - передается в бухгалтерию. При отпуске товаров в карте указывается дата отпуска, номер расходного товарного документа, наименование получателя, вид транспорта, место отправления, наименование, сорт и количество отпущенного товара.

Полный расход каждой партии товаров оформляется в партионной карте подписями уполномоченных лиц с указанием данных о применении норм естественной убыли и окончательного результата учета товаров либо составлением акта о расходе товаров по партиям (ф. № M X-12). При обнаружении расхождений данных по приходу и расходу товаров по отдельной партии оформляется акт по ф. № M X-11.

После полного выбытия партии товаров партионная карта ск лада передается в бухгалтерию для проверки. 
При партионном способе учета можно определить недостачи или излишки сразу после реализации всей партии товара, не дож идаясь общей инвентаризации. Для проверки правильности учетных записей на начало каждого месяца составляют оборотную ведомость по данным партионных карт. В ведомости для каждой карты выделяется отдельная строка. Суммовые итоги оборотной ведомости сверяют с оборотами и сальдо счета 41 «Товары», а натуральные показатели - с данными ск ладск ого учета материально ответственных лиц.

При сортовом способе хранения товары хранятся на складе по сортам и каждый вновь поступающий товар присоединяется к имеющимся товарам того же наименования и сорта. таким образом, отдельного учета поступающих товаров одного наименования с различной фактической себестоимостью не ведется.

При данном способе материально ответственные лица ведут учет движения товаров в журнале учета движения товаров на складе (ф. № ТОРГ-18) или на карточках учета. На каждое наименование и сорт товаров открывается одна или несколько страниц в товарной книге или отдельная карточка, где отражают приход, расход и остатки товаров. После каждой записи по движ ению товаров выводится остаток .

На складах с узким ассортиментом товаров и небольшим объемом товарных операций материально ответственные лица могут вести учет непосредственно в товарном отчете (ф. № ТОРГ-29).

При ведении складского учета сортовым способом в бух- 
галтерии учет можно вести количественно-суммовым либо оперативно-бухгалтерским (сальдовым) методом.

При количественно-суммовом методе в бухгалтерии на каждое наименование товаров и сорт открываются карточки количественно-стоимостного учета (ф. № ТОРГ-28). Записи в карточке производятся по приходным и расходным документам. При этом возможно группировать движение товара каж дого наименования по приходу и расходу в накопительной ведомости и заносить в карточки общие итоги. В конце месяца в карточках подсчитывают итоги прихода, расхода товаров, определяют остатки и по всей номенклатуре товара составляют оборотную ведомость в количественном и суммовом выражении. Натуральные показатели оборотной ведомости сверяют с данными складского учета, а суммовые - с оборотами и сальдо по счету 41 «Товары» субсчет 1 «Товары на складах».

При ведении учета в бухгалтерии сальдовым методом не ведется учет товаров по наименованиям, сортам, количеству и ценам, т.е. в записях бухгалтерского учета не дублируются складской учет. Бухгалтер периодически проверяет правильность записей в складск ом учете выведенных количественных остатков. Регистры складского учета одновременно являются и регистрами бухгалтерского учета. В конце месяца остатки товаров в натуральном выражении из регистров складского учета заносятся материально ответственными лицами в ведомости учета остатков товарно-материальных ценностей по наименованиям, количеству и цене (ф. № M X-19). В бухгалтерии исчисляется общая стоимость товаров по ведомости учета, 
которая сверяется с данными субсчета 41/1 «товары на складax».

\section{4. Вопросы для самоконтроля}

1. К акими документами оформляется поступление товаров в торговое предприятие?

2. Какие документы являются основанием для предъявления претензий поставщику по качеству и количеству поступивших товаров?

3. Методологическая основа бухгалтерского учета товаров?

4. Из как их элементов ск ладывается фрактическая себестоимость приобретенных товаров?

5. Какие варианты учета приобретения товаров существуют?

6. В чем состоит целесообразность использования в учете счетов 15 и 16 ?

7. Какая система счетов используется для отражения поступления товаров в торговое предприятие?

8. Какие организации могут использовать в учете продаж ные цены?

9. Что представляют собой курсовые разницы и как они отраж аются в учете?

10. Назовите способы аналитического учета товаров. 


\section{ЛЕКЦИЯ 4.}

\section{УЧЕТ РАСХОДОВ ТОРГОВОЙ ОРГАНИ ЗАЦИИ}

\section{План лекции.}

1. Понятие издержек и расходов

2. Синтетическ ий учет расходов на продаж у

3. Аналитический учет издерж ек обращения

4. Учет транспортных расходов

5. Учет издержек обращения на остаток товаров

6. Вопросы для самоконтроля

\section{1. Понятие издерж ек и расходов}

Основные принципы отражения расходов в бухгалтерском учете определяются ПБУ «Расходы организации» (ПБУ 10/99). Расходами организации признается уменьшение экономических выгод в результате выбытия активов (денежных средств, иного имущества) и (или) возникновения обязательств, приводящее к уменьшению капитала этой организации, за исключением уменьшения вкладов по решению участников (собственников имущества).

Расходы организации в зависимости от их характера, условий осуществления и направлений деятельности органи- 
зации подразделяются на расходы по обычным видам деятельности и прочие расходы.

Расходами по обычным видам деятельности в организации торговли являются расходы, связанные с приобретением и продаж ей товаров.

Расходы по обычным видам деятельности формируют:

- расходы, связанные с приобретением материалов, товаров и иных МПЗ;

- расходы, возникающие непосредственно в процессе продажи (перепродажи) товаров (расходы по содержанию и эксплуатации основных средств, к оммерческ ие расходы и др.).

расходы признаются в бухгалтерском учете при наличии следующих условий:

- расход производится в соответствии с к онкретным договором, требованием законодательства и нормативных актов, обычаями делового оборота;

- сумма расхода мож ет быть определена;

- имеется уверенность в том, что в результате конкретной операции произойдет уменьшение экономических выгод организации.

Если в отношении любых расходов, осуществленных организацией, не исполнено хотя бы одно из названных условий, то в бухгалтерском учете признается дебиторская задолженнОСТЬ.

Издерж к и обращения - это часть расходов, которые несет торговая организация в процессе движения товаров до потребителя. К ним относят расходы на транспортировку, подра- 
ботку, упаковку, хранение и продажу товаров, а также административно управленческие расходы. не учитываются в составе издержек обращения следующие расходы, относимые к прочим в соответствии с ПБУ 10/99.

Существует несколько классификаций издержек обращения.

Расходы по обычным видам деятельности, к которым следует отнести и издержки обращения, группируются по следующим элементам: материальные затраты; затраты на оплату труда; отчисления на социальные нужды; амортизация; прочие: налоги и сборы, оплата консультационных и информационных услуг, представительские расходы и др.

Для целей управления организуется учет расходов по статьям издерж ек обращения: транспортные расходы; расходы на оплату труда; отчисления на социальные нужды; расходы на аренду и содержание зданий, сооружений, помещений и оборудования; амортизацию основных средств; расходы на ремонт основных средств; износ санитарной одежды; расходы на хранение, подработку, подсортировку и упаковку товаров; расходы на рекламу; потери товаров и технологические отходы; расходы на тару; прочие расходы.

Для торговых организаций большое значение имеет группировка издерж ек по периодам, которая предполагает деление издержек на расходы отчетного периода и расходы будущих периодов.

Расходы отчетного периода относятся к текущему отчетному периоду, в котором они произведены. Расходы, произве- 
денные в отчетном периоде, но относящиеся к следующим отчетным периодам, отраж аются отдельно как расходы будущих периодов и подлежат отнесению на издержки обращения (либо на соответствующие источники средств организации) в течение срока, к которому они относятся.

К расходам будущих периодов относятся: затраты по неравномерно производимому ремонту основных средств (когда предприятием не создается фонд или резерв для ремонта основных средств); арендная плата за аренду отдельных объек тов основных средств; расходы по подписке на периодическ ие издания для служ ебного пользования; расходы по оплате услуг телефонной, радио- и других видов связи; другие аналогичные расходы.

В зависимости от способа отнесения затрат на издержки отдельных товарных групп и структурных подразделений выделяют прямые и косвенные расходы. Прямые издержки обращения - это затраты, которые на основании первичных документов напрямую могут быть отнесены на ту или иную товарную группу. К освенные издержки обращения невозможно напрямую без предварительных расчетов распределить между товарными группами (например, заработная плата управленческого персонала).

Группировка по отношению к остаткам товарных запасов разделяет затраты на издержки обращения, приходящиеся на остаток товаров, и издержки, относящиеся к реализованным товарам. Причем в издержки на остаток товаров включают лишь расходы, связанные с их приобретением (доставкой), и 
1. Понятие издержек и расходов

не вк лючаются расходы по их продаже, так как товары еще не проданы. Данная классификация позволяет определить сумму издержек, непосредственно участвующих в фрормировании финансового результата.

В зависимости от влияния на налогооблагаемую прибыль затраты подразделяют на участвующие и не участвующие в уменьшении налогооблагаемой прибыли. В составе издержек выделяют нормируемые и ненормируемые расходы. Нормируемые расходы не в полной мере уменьшают налогооблагаемую часть прибыли, а лишь в пределах нормативов, установленных государством. К расходам, не уменьшающим налогооблагаемую прибыль, относят сверхнормативные суммы нормируемых расходов, а именно: представительские расходы, компенсацию за использование для служебных поездок личных легковых автомобилей, к омандировочные расходы и др.

По рациональности использования все расходы торгового предприятия можно разделить на производительные и непроизводительные. Производительные дают полезный результат: расходы на реализацию товаров обеспечивают предприятию получение розничного товарооборота. Непроизводительные расходы полезного результата не дают, но они бывают неизбежными в процессе осуществления предприятием торговохозяйственной деятельности. Прежде всего, это потери товаров в виде естественной убыли. Предприятие должно стремиться к снижению непроизводительных потерь путем улучшения организации доставки, хранения и реализации товаров.

Основными задачами учета издержек обращения явля- 
ются обеспечение своевременного, полного и достоверного отражения фрактических расходов и контроль за использованием материальных, трудовых и финансовых ресурсов.

\section{2. Синтетическ ий учет издерж ек обращения}

Синтетический учет издержек обращения ведется на ак тивном счете 44 «Расходы на продажу». По дебету счета 44 «Расходы на продажу» собираются все произведенные организацией расходы, связанные с приобретением, хранением и продаж ей товаров, а по кредиту осуществляется их списание. При этом дебетовое сальдо показывает остаток издержек обращения на остаток товаров на конец отчетного периода. В конце отчетного периода издерж ки обращения, приходящиеся на реализованные товары, списываются на счет 90 «Продажи». При частичном списании в торговых организациях подлежат распределению расходы на транспортировку (между проданным товаром и остатком товара на конец каж дого месяца).

В учете издерж ки обращения собираются по дебету счета 44 «Расходы на продажу», при этом с данным счетом корреспондируют различные счета в зависимости от источника расходов и затрат:

$K^{m} 02$ «Амортизация основных средств», 05 "Амортизация нематериальных активов» - начисляется износ по основным средствам, нематериальным активам;

$K^{m} 10$ «Mатериалы» - списываются материалы, израсходованные, например, при хранении товара; 
$K^{m} 60$ «Расчеты с поставщиками и подрядчиками», 76 «Расчеты с разными дебиторами и кредиторами» - получен счет за услуги производственного характера (по охране объектов, по осуществлению транспортировки, за информационные, консультационные и прочие услуги и т. о.);

$K^{m} 68$ «Расчеты по налогам и сборам» - начисляются налоги и отчисления, относящиеся на издержки обращения (земельный и др. налоги);

$K^{m} 70$ «Расчеты с персоналом по оплате mруда» - начисляется заработная плата сотрудникам торговли;

$K^{m} 69$ «Расчеты по социальному страхованию и обеспечению» - начисление единого социального налога на оплату труда и выплаты, относящиеся на издержки обращения;

$K^{m} 71$ «Расчеты с подотчетными лицами» - списываются командировочные, представительские расходы, отнесенные к производственным, по авансовым отчетам сотрудников;

$K^{m} 96$ «Резервы предстоящих расходов» - образование резервов на оплату отпусков, ремонт;

$K^{m} 97$ «Расходы будущих периодов» - отнесение данных расходов к расходам отчетного периода при его наступлении.

Собранные на счете 44 расходы на продажу списываются в части реализованных товаров на счет учета реализации, что отражает бухгалтерская проводка:

$Д^{m} 90$ «Продажи»- Km 44 «Расходы на продажу»

Данные расходы могут быть списаны как недостающие дебетуется счет 94 «Недостачи и потери от порчи иенностей», а также при стихийных бедствиях отнесены на счет 91 
«Прочие доходы и расходы».

При принятии к бухгалтерскому учету расходов в качестве издержек обращения необходимо соблюдать принцип временной определенности фактов хозяйственной деятельности. Он означает, что расходы отражаются в бухгалтерском учете того периода, в котором они совершены независимо от фактического времени поступления или выплаты денежных средств, связанных с этими фактами. Расходы, произведенные в отчетном периоде, но относящиеся к следующим отчетным периодам, должны учитываться на счете 97 «Расходы будущих периодов» и подлежат отнесению на издержки обращения в течение срока, к которому они относятся, еж емесячно равными частями, согласно утвержденным руководителем предприятия расчетам.

В целях равномерного отражения предстоящих расходов в издержках обращения отчетного периода предприятия торговли могут создавать резервы предстоящих расходов, которые учитываются на счете 96 «Резервы предстоящих расходов». За счет отчислений, относимых на издержки обращения и производства, создаются следующие резервы: на предстоящую оплату отпусков работникам; на выплату ежегодного вознаграждения за выслугу лет и по итогам работы за год; фонд или резерв на ремонт основных средств; резерв на списание естественной убыли в пределах утвержденных норм естественной убыли.

Образование резервов производится за счет отчислений, вк лючаемых в издержки обращения и производства в сроки, 
обоснованные специальными расчетами, утвержденными руководителем предприятия.

В конце отчетного года в случае превышения фактически начисленного резерва над суммой расчета, подтвержденного инвентаризацией, производится сторнировочная запись издерж ек обращения.

В случаях, когда ок ончание ремонтных работ по объектам с длительным сроком их производства происходит в следующем за отчетным году, остаток резерва на ремонт основных средств не сторнируется.

По окончании ремонта излишне начисленная сумма резерва присоединяется к финансовым результатам.

Единовременные затраты могут при отсутствии резервов списываться на издержки обращения и производства того месяца, в котором они произведены .

Также не относятся на затраты предприятия расходы капитального характера (соответствующие затраты включаются в издержки посредством начисления амортизации) и расходы, не связанные с торговой (производственной) деятельностью.

\section{3. Аналитическ ий учет издерж ек обращения}

Аналитический учет по счету 44 «Расходы на продажу» ведется по видам и каж дой статье расходов.

В целях планирования, учета и отчетности предприятия торговли применяют следующие статьи издержек обращения и производства: 
- транспортные расходы;

- расходы по оплате труда;

- отчисления на социальные нужды;

- расходы на аренду и содержание зданий, сооружений, помещений, оборудования и инвентаря;

- амортизация основных средств;

- расходы на ремонт основных средств;

- амортизация санитарной и специальной одежды, столового белья, посуды, приборов;

- расходы на топливо, газ, электроэнергию для производственных нужд;

- расходы на хранение, подработку, подсортировку и упаковку товаров;

- расходы на рекламу;

- потери товаров и технологическ ие отходы;

- расходы на тару;

- прочие расходы.

На статью «Транспортные расходы» относятся:

- оплата транспортных услуг сторонних организаций за перевозки товаров и продуктов;

- оплата услуг организаций по погрузке товаров и продук тов в транспортные средства и выгрузке из них, плата за экспедиционные операции и другие услуги;

- стоимость материалов, израсходованных на оборудование транспортных средств и утепление;

- плата за временное хранение грузов на станциях, в портах, аэропортах в пределах нормативных сроков, установлен- 
ных для вывоза грузов в соответствии с заключенными договорами;

- плата за обслуж ивание подъездных путей и ск ладов необщего пользования.

Расходы, связанные с доставкой товаров и продуктов транспортом и персоналом предприятия торговли, подлежат вк лючению в соответствующие статьи издержек обращения и производства (расходы на оплату труда, амортизация основных средств и др.).

Расходы на перевозку топлива, льда, ремонтностроительных и других материалов относятся на увеличение их стоимости (счета: 10 «Материалы», 07 «Оборудование к установке»).

Расходы на перевозку, погрузку и выгрузку порожней тары при возврате ее поставщикам или отправке тарособирающим и тароремонтным организациям учитываются на cmaтье «Расходы на тару».

На статью «Расходы на оплату труда» относятся:

- затраты на оплату труда основного торговопроизводственного персонала предприятия с учетом премий за производственные показатели;

- стимулирующие и компенсирующие выплаты;

- компенсации женщинам, находящимся в отпуске по уходу за детьми до определенного законодательством возраста;

- затраты на оплату труда работников несписочного состава, занятых в основной деятельности. 
На статье «Отчисления на социальные нужды» отражаются обязательные отчисления по установленным законодательством нормам органам:

- государственного социального страхования;

- пенсионного фонда;

- медицинского страхования.

Отчисления на социальные нужды производятся от расходов на оплату труда работников предприятий торговли, включаемых в издержки обращения и производства по cmamье «Расходы на оплату труда» в соответствии с установленным зак онодательством порядком.

Кроме того, по данной статье отражаются расходы на обязательное страхование от несчастных случаев на производстве и профессиональных заболеваний. Базой для начисления таких взносов является начисленная по всем основаниям оплата труда работников.

По статье «Расходы на аренду и содержание зданий, сооружений, помещений, оборудования и инвентаря» отраж аются:

- плата за текущую аренду торгово-складских зданий, строений и помещений, сооружений, оборудования и инвентаря и других отдельных объектов основных средств, причитающаяся арендодателю;

- расходы на отопление, освещение, водоснабжение, канализацию и другие коммунальные услуги;

- расходы на содержание в чистоте помещений, уборку примыкающих к ним участков территории, вывоз мусора; 
- стоимость предметов и средств ухода за помещениями;

- стоимость электроэнергии, потребленной на приведение в движение подъемников, лифтов, транспортеров, торговых автоматов, контрольно-кассовых машин и т. п.;

- расходы на проверку весов, счетчиков и других измерительных приборов;

- расходы на содержание и ремонт сигнализационных устройств;

- расходы на проведение противопожарных мероприятий;

- плата сторонним организациям за пожарную и сторожевую охрану;

- расходы на обслуживание подъемно-транспортных механизмов и другого оборудования сторонними организациями.

На статье «Амортизация основных средств» отраж аются суммы амортизационных отчислений на полное восстановление основных производственных средств, начисленные исходя из их балансовой стоимости и утвержденных норм амортизационных отчислений.

Предприятия торговли, осуществляющие свою деятельность на условиях аренды, по статье «Амортизация основных средств» отражают амортизационные отчисления на полное восстановление как по собственным, так и по арендованным основным средствам.

Статья «Расходы на ремонт основных средств» включает расходы на проведение всех видов ремонтов (текущих, средних, капитальных) основных производственных средств, в 
том числе расходы по ремонту арендованных основных средств, если это предусмотрено договором аренды.

В случае неравномерного осуществления ремонта основных средств в течение года предприятие торговли может образовывать резерв расходов на ремонт основных средств за счет еж емесячных отчислений. Суммы этих отчислений определяются как одна двенадцатая годовой предполагаемой суммы расходов на ремонт.

Излишне образованный в отчетном году резерв сторнируется в конце отчетного года. При превышении фрактическ их расходов над суммой образованного резерва сумма превышения относится на издержки обращения и производства по указанной статье.

В случае окончания ремонтных работ в следующем отчетном году резерв расходов на ремонт основных средств разрешается образовывать исходя из отчетного и следующего годов.

Предприятия торговли, образующие ремонтный фонд для обеспечения равномерного включения затрат на проведение значительного объема ремонта основных производственных средств в издержки обращения и производства, по этой статье вк лючают отчисления в ремонтный фонд, определяемые исходя из балансовой стоимости основных производственных средств и норматива отчислений, утверждаемого предприятием торговли на 5 лет.

В статью «Амортизация санитарной и специальной одежды, столового белья, посуды, приборов» включаются: 
- расходы на приобретение столового белья, санитарной и специальной одежды, обуви, санпринадлежностей, столовой посуды и приборов;

- потери от боя посуды, поломки и повреждения приборов в пределах норм, утверж денных в установленном порядке;

- плата прачечным, ремонтным мастерским и другим предприятиям за стирку, дезинфекцию и починку столового белья, специальной одежды, обуви и санпринадлеж ностей;

- стоимость материалов, израсходованных на стирку и починку (моющих средств, ниток, тканей, пуговиц);

- расходы на ремонт хозяйственного инвентаря.

Заработная плата лиц, не входящих в списочный состав, привлеченных для выполнения разовых работ - стирки и починки столового белья, специальной одежды и обуви, отражается по статье «Расходы на оплату труда».

По статье «Расходы на топливо, газ и электроэнергию для производственных нужд» в основном отраж аются расходы на предприятиях общественного питания:

- фак тическ ая стоимость топлива, потребленного на подогрев воды, приготовление пищи;

- стоимость электроэнергии, газа и пара, израсходованных на приведение в движение оборудования и механизмов.

На этой статье не отражается себестоимость электроэнергии, потребленной холодильным оборудованием. Эту стоимость относят на статью «Расходы на хранение, подработку, подсортировку и упаковку товаров».

На статью «Расходы на хранение, подработку, подсор- 
тировку и упаковку товаров» относят:

- фактическую стоимость материалов, потребленных при подработке, переработке, сортировке, фасовке и упаковке товаров;

- плату за услуги сторонних организаций по фасовке и упак овке товаров;

- расходы на содерж ание холодильного оборудования;

- оплату услуг сторонних организаций по техническому обслуж иванию холодильного оборудования;

- фрактическую себестоимость льда, потребленного для охлаж дения товаров и продуктов;

- плату за временное хранение товаров на складах сторонних организаций;

- расходы на дезинсекцию (уничтожение вредных насекомых) и дератизацию (истребление мышей, крыс и других грызунов);

- другие расходы на создание условий для хранения товаров и продуктов.

Организации розничной торговли могут использовать упаковочные материалы двумя способами: как вспомогательное средство для сохранности реализуемых товаров или как самостоятельный товар.

В первом случае покупатели не оплачивают упаковку отдельно, а стоимость материалов, потребленных при подготовке товаров к продаже, относится на издержки обращения. К таким материалам относятся: оберточная бумага, полиэтиленовые пакеты, проволока и т.д. 
Если покупатель приобретает товар и отдельно оплачивает материал, в который он упакован (например, подарочная коробка), то стоимость такого упаковочного материала в издержки обращения не включается. Данный материал сам становится товаром.

На статью «Расходы на рекламу» относятся следующие расходы:

- на офрормление витрин, выставок, выставок-продаж, к омнат образцов товаров;

- на разработку и печатание рекламных изданий;

- на разработку и изготовление эскизов этикеток, образцов оригинальных и фирменных пакетов, упак овк и и т. д.;

- на рекламные мероприятия через средства массовой информации;

- на световую и иную наружную рекламу;

- на приобретение, изготовление, копирование и демонстрацию рекламных кино-, видео-, диафильмов и т. п.;

- на изготовление стендов, муляжей, рекламных щитов, ук азателей;

- на уценк у товаров, полностью или частично потерявших свое первоначальное качество во время экспонирования в витринах, торговых залах магазинов и на выставках;

- стоимость образцов товаров, переданных в соответствии с контрактами и иными документами непосредственно покупателям или посредническим организациям бесплатно и не подлеж ащих возврату;

- на проведение других рекламных мероприятий, связан- 
ных с торговой деятельностью.

Расходы на торговую рекламу, включенные в состав издержек обращения, при налогообложении принимаются в пределах установленных норм.

По статье «Потери товаров и технологические отходы» отраж аются: потери товаров и продуктов при железнодорож ных, водных, воздушных, автомобильных перевозках, хранении и продаже в пределах действующих норм естественной убыли.

Утвержденные нормы естественной убыли при перевозке, хранении и продаже товаров и продуктов являются предельными. Списание товаров и продуктов в пределах норм естественной убыли производят в случаях, если при приемке или инвентаризации выявлена фактическая недостача.

В целях равномерного отражения предстоящих расходов в издержках обращения и производства на холодильниках, хладокомбинатах, базах овощных и продовольственных товаров, торговых предприятиях, имеющих склады, ежемесячно начисляется резерв на списание естественной убыли товаров в пределах действующих норм естественной убыли.

На этой статье также отраж аются:

- убытки от недостачи и потери от порчи товаров, продук тов и сырья сверх норм естественной убыли в тех случаях, когда конкретные виновники не установлены;

- потери от списания долгов по недостачам товарноматериальных ценностей, денежных средств и другого имущества, во взыскании которых отказано судом вследствие не- 
обоснованности исков.

Потери и недостачи товаров и продуктов отражаются на этой статье по покупным ценам.

Основанием для списания убытков от недостачи, порчи сверх норм естественной убыли, когда виновники не установлены или во взыскании которых отказано судом, является обоснованное заключение, утвержденное руководителем предприятия торговли .

На статье «Расходы на тару» отраж аются:

- амортизация тары-оборудования;

- расходы на ремонт тары-оборудования;

- амортизация многооборотной тары, возмещенная поставщик ам в соответствии с условиями поставк и товаров;

- расходы, связанные с ремонтом и естественным износом тары-оборудования в части, возмещенной поставщикам;

- стоимость тары, списанной из-за естественного износа;

- расходы на перевозку, погрузку и выгрузку порожней тары, осуществляемую сторонними организациями при возврате ее поставщикам или сдаче тарособирающим организациям;

- расходы на очистку и обработку тары;

- разница в ценах на тару между приемными - при оприходовании и сдаточными - при возврате порожней;

- другие расходы на тару.

На статье «Прочие расходы» отражаются:

- суммы затрат по уплате налогов, сборов и отчислений в бюдж ет и в специальные внебюдж етные фонды; 
- вознаграждения за изобретения и рационализаторские предлож ения;

- амортизация по нематериальным активам;

- расходы по обеспечению нормальных условий труда и техники безопасности;

- расходы на устройство и содержание комнат отдыха, душей, раздевалок, шкафчиков для специальной одежды, сушилок и другого оборудования (где предоставление этих услуг работающим связано с особенностями производства и предусмотрено коллективным договором).

- расходы по ведению реестра акционеров;

- расходы по ведению кассового хозяйства;

- оплата консультационных, информационных и аудиторск их услуг; компенсации за использование для служ ебных поездок личных легковых автомобилей;

- оплата услуг почтовой, телефонной, телеграфной и фак симильной связи; расходы на содержание и эксплуатацию собственных телефонных станций, коммутаторов, диспетчерской связи и радиосвязи;

- расходы на приобретение канцелярских принадлежностей и бланков, на типографские и переплетные работы;

- расходы на подписку периодических изданий для служебного пользования, приобретение справочной литературы, инструктивных и других служебных материалов;

- расходы на служебные разъезды работников в пределах пункта нахож дения предприятия торговли;

- расходы на командировки, связанные с торгово- 
производственной деятельностью: оплата за проезд командированных к месту назначения и обратно, за наем жилого помещения, суточных за время нахож дения в командировке;

- другие затраты, подлежащие включению в состав издерж ек, но не относящиеся к ранее перечисленным статьям.

Каждое предприятие самостоятельно выбирает для себя организацию аналитического учета. Это могут быть многографные карты или ведомости, где каждой отдельной статье отводится специальная графа. Итог записанных в каждой графе сумм показывает размер произведенных расходов. В отдельной итоговой графе показывается общая сумма издержек. Итог записей в этой графе должен быть равен данным соответствующего синтетическ ого счета 44 «Расходы на продаж у». Учет в картах или ведомостях ведется отдельно по структурным подразделениям, а внутри них - по статьям издержек обращения. Возможен вариант, когда учет ведется в разрезе статей издержек обращения, а внутри - по структурным подразделениям.

В целях управленческого учета целесообразно вести учет затрат по складам, розничным точкам и т.п. Такой учет позволит проводить анализ эффективности работы каждой торговой точки.

\section{4. Учет транспортных расходов}

Наибольшую сложность представляет учет транспортных расходов. Под транспортными расходами понимаются расхо- 
ды по транспортным услугам сторонних организаций. Расходы на транспортировку собственными силами и средствами организации относятся к другим статьям расходов: амортизационные расходы, расходы на оплату труда и т.д.

Порядок транспортировки товаров от продавца до покупателя определяется условиями договора купли-продажи (поставки). Расходы по доставке товаров от поставщика до покупателя по условиями договора может нести либо поставщик, либо пок упатель.

Суммы произведенных расходов отражаются по дебету счета 44 «Расходы на продажу».

Торговым организациям предоставлено право выбирать, каким способом учитывать расходы по заготовке и доставке товаров до центральных ск ладов, производимые до момента их передачи в продаж у:

- включать эти затраты в фактическ ую себестоимость товаров и учитывать на счете 41 «Товары»;

- относить к расходам на продажу и учитывать на счете 44 «Расходы на продажу».

Применение того или иного варианта определяется учетной политикой организации.

Если расходы по заготовке и доставке товаров включаются в расходы на продажу, то они подлежат распределению между проданными товарами и остатком товаров на конец каж дого месяца.

Расходы по заготовке и доставке, относящиеся к реализованным в текущем месяце товарам, списываются с кредита 
счета 44 «Расходы на продажу» в дебет счета 90 «Продажи», субсчет 90-2 «Себестоимость продаж».

Расходы по заготовке и доставке товаров, относящиеся к остаткам товаров на складе, определяются по среднему проценту за текущий месяц с учетом переходящего остатка на начало месяца в следующем порядке:

средний проиент расходов по заготовке и доставке $=\frac{T P o+T P m}{T p+T o} \cdot 100 \%$, где TPо - расходы по заготовке и доставке, приходящиеся на остаток товаров на складе на начало месяца;

TPm - расходы по заготовке и доставке, осуществленные в текущем месяue;

Тр - стоимость товаров, реализованных в текущем месяце;

То - стоимость остатка товаров на складе на конец месяца.

Сумма расходов по заготовке и доставке, относящаяся к остатку товаров на ск ладе определяется умнож ением среднего процента на сумму остатка товаров на конец месяца.

При любом варианте учета расходов по заготовке и доставке товаров относятся на затраты и отражаются по дебету счета 90 «Продажи» только расходы, относящиеся к реализованным товарам. Оставшиеся расходы остаются либо в стоимости товаров на складах на счете 41 «Товары», либо на счеmе 44 «Расходы на продажу».

Расходы, связанные с работой собственного транспорта организации (затраты транспортного цеха), возможно учитывать с использованием счета 23 «Вспомогательные производства». Суммы, накопленные на счете 23, списываются в дебет счета 44 «Расходы на продажу». 


\section{5. Учет издерж ек обращения на остаток товаров}

Для определения фринансового результата от продажи товаров торговые организации в конце каждого месяца производят списание издержек обращения, приходящихся на реализованные товары.

По дебету счета 44 «Расходы на продажу» постепенно накапливаются все производственные расходы торгового предприятия, относящиеся как к уже реализованным товарам, так и к товарам, оставшимся на конец месяца еще не проданными. Разграничение расходов между реализованными товарами и товарными запасами осуществляется с помощью ежемесячного расчета издержек обращения на остаток товаров. При расчете соответствующих издержек учитываются транспортные расходы. Другие затраты, в силу их незначительности, не выделяются и в полной сумме списываются через счет реализации на финансовые результаты.

Списание в конце месяца издерж ек обращения возможно одним из двух способов:

1. В соответствии с п.9. ПБУ 10/99 «Расходы организации» издержки обращения могут признаваться в себестоимости проданных товаров полностью в отчетном году в качестве расходов по обычным видам деятельности. При этом сумма фрактических издержек списывается в полном объеме в дебет счета 90 «Продаж и».

2. Согласно Плану счетов и Инструкции по его примене- 
нию, а также методическим рекомендациям издержки обращения могут распределяться между реализованными товарами и остатком нереализованных товаров. В конце месяца сумма издержек обращения, приходящаяся на реализованные за текущий месяц товары, списывается в дебет счета 90 «родажи». Сальдо счета 44 «Расходы на продажу» субсчет «Издержки обращения» равно сумме издержек обращения, приходящейся на остаток нереализованных на конец отчетного периода товаров.

Сумма издерж ек обращения на остаток товаров исчисляется по среднему проценту издержек обращения за отчетный месяц с учетом переходящего остатка на начало месяца в следующем порядке:

- суммируются транспортные расходы на остаток товаров на начало месяца и произведенные в отчетном месяце;

- определяется сумма товаров, реализованных в отчетном месяце (кредитовый оборот счета 90 «Продажи»), и остатка товаров на конец месяца (сальдо конечное счета 41 «Товары»);

- отношением определенной в п. 1 суммы издержек обращения к сумме реализованных и оставшихся товаров (в п. 2) определяется средний процент издержек обращения к общей стоимости товаров;

- умножением суммы остатка товаров на конец месяца на средний процент указанных расходов определяется их сумма, относящаяся к остатку нереализованных товаров на конец месяца;

- определяется сумма издержек обращения (в части 
транспортных расходов), списываемых в отчетном периоде на реализацию.

Списание издержек обращения на реализованные товары оформляется следующей бухгалтерской записью:

Дm 90 «Продажи»- Кm 44 «Расходы на продажу» субсчет «Издержки обращения».

Исходя из правил нормативных документов по бухгалтерскому учету торговые организации имеют право самостоятельно решать вопрос о составлении или несоставлении расчета издержек обращения, приходящихся на остаток товаров. данное решение закрепляется в приказе об учетной политике. Методическими указаниями по бухгалтерскому учету материально-производственных запасов, утв. приказом Минфина России от 28.12.2001 г. № 119, рекомендуется составлять такой расчет, если величина транспортно-заготовительных расходов, связанных с приобретением и доставкой товаров, составляет более $10 \%$ общего объема выручк и от продаж и, а также при их неравномерном уровне в течение года. В соответствии с Налоговым кодексом торговые организации в целях налогового учета должны распределять транспортные расходы между проданными товарами и остатком товаров на ск ладах. Поэтому в целях избежания разниц между бухгалтерским и налоговым учетом, торговым организациям целесообразно производить расчет издерж ек на остаток товаров. 


\section{6. Вопросы для самок онтроля}

1. Что понимается под «расходами», «затратами» и «издерж ками обращения»?

2. Какие виды затрат торговых организаций не относятся к издержкам обращения?

3. Укажите по каким элементам затрат учитываются издержки обращения.

4. Какой счет предназначен для обобщения информации о расходах, связанных с приобретением, хранением и продажей товаров? дайте ему характеристику.

5. Как организуется аналитический учет издержек обращения?

6. Как рассчитать сумму издержек обращения, приходящихся на остаток товаров? 


\section{ЛЕКЦИЯ 5.}

\section{УЧЕТ ТАРЫ}

\section{План лекции.}

1. Учет тары.

2. Вопросы для самоконтроля.

\section{1. Учет тары}

Tара - вид запасов, предназначенных для упаковки, транспортировки и хранения товаров и других материальных ценностей.

Бухгалтерский учет тары ведется по следующим видам: древесина; картон и бумага; металл; пластмасса; стекло; ткани и нетканые материалы.

В составе тары учитываются также материалы и детали, предназначенные специально для изготовления и ремонта тары - тарные материалы (детали для сборки ящиков, бочковая клепка, железо обручное, пробка корковая, фольга).

В торговом предприятии может быть сосредоточено большое количество тары под товаром и порожней. Порядок контроля за поступлением и правильным оприходованием тары в основном такой же, что и товаров. Одновременно с проверкой цен на товары определяется правильность цен на тару. Приемка поступившей тары осуществляется на основании счетов-фрак тур, товарно-транспортных нак ладных и других со- 
проводительных документов.

Различают несколько категорий тары: многооборотная (возвратная) и однократного использования.

Возвратная тара используется многократно, подлежит обязательному возврату поставщику или сдаче тароремонтным организациям. Гарантией возврата тары является взимаемый поставщиком залог, который возвращается после получения назад порож ней тары в исправном состоянии.

К возвратной таре могут быть отнесены металлическая и пластмассовая тара (корзины, бочки, бидоны), деревянная тара (ящики, бочки), стеклянная тара (бутылки, банки), картонная тара (ящики из картона), тара из тканей (мешки, упаковочные ткани), а также специальная тара, т.е. специально изготовленная для затаривания отдельных товаров.

Тара однократного использования (бумажная, картонная, полиэтиленовая и др.), а также мешки бумажные и из полимерных материалов, использованные для упаковки товаров, как правило, включаются в себестоимость упакованных в нее товаров и покупателем отдельно не оплачиваются.

По своим функциям тара различается на внешнюю упаковку и непосредственную упаковку.

Непосредственная упаковка характерна тем, что она неотделима от влож енного в нее товара и может быть использована самостоятельно только после расходования этого товара, поэтому она со ск лада отпуск ается вместе с товаром. Такая тара берется на учет и подлеж ит возврату на склад после использования (расходования) вложенных в нее материальных цен- 
ностей, если она может быть использована внутри организации или продана.

Тара-оборудование - это вид тары, предназначенный для хранения, транспортировки и продажи из него товаров. тараоборудование, являющаяся многооборотной тарой, право собственности на которую принадлежит организациипоставщику товаров, учитывается им на балансе и подлежит обязательному возврату покупателями поставщикам. При поставке товаров с такой тарой стоимость тары-оборудования в стоимость товара не включается, и в расчетных документах показывается отдельной строкой.

К роме того, в торговом предприятии должен быть предусмотрен раздельный учет тары, которая:

- оприходована на основании товаросопроводительных док ументов поставщиков;

- не включена в товаросопроводительные документы поставщика, а оприходована с составлением акта и оценкой торговым предприятием;

- относится к основным средствам.

Тара поступает на предприятия торговли в основном вместе с товарами от поставщиков и приходуется материально ответственными лицами в те же сроки, что и товары на основании сопроводительных документов. При этом проверяется соответствие фрактического количества тары количеству, указанному в сопроводительных документах, соответствие качества тары техническим условиям, правильность маркировки и цен. 
Тару учитывают в местах ее хранения и в бухгалтерии предприятия. при этом материально ответственные лица ведут учет тары по количеству, наименованиям, ценам в товарной книге, записи в которой производят на основании первичных документов на поступление и выбытие товара.

Торговые предприятия учет тары ведут на счете 41 «Tовары», субсчет 3 «Тара под товаром и порожняя». По дебету 41/3 отражается оприходование поступившей тары в корреспонденции со счетами 60, 76, а по кредиту - выбытие (списание) тары.

К роме того, для учета тары мож ет использоваться счет 10 «Материалы» субсчет 4 «Тара и тарные материалы». Тараоборудование соответствует признакам основных средств и учитывается на счете 01 "Основные средства».

Тара принимается к бухгалтерскому учету по фактической себестоимости. Фактическая себестоимость приобретаемой тары (кроме тары, поступившей с поставленными товарами) слагается из всех расходов по ее покупке и доставке в организацию или затрат по ее изготовлению.

Учет движения тары при наличии большого количества разных видов тары с разными ценами производят по средним учетным ценам, которые устанавливают по отдельным группам тары применительно к ее назначению. При этом разница между ценами приобретения и средними учетными ценами мож ет относиться на счет 42 «Торговая наценка».

Если тару учитывают по средним учетным ценам, то в течение месяца разницу между стоимостью по ценам приобре- 
тения и средними учетными ценами можно отражать на счете 16 «Отклонения в стоимости материальных ценностей». В конце месяца дебетовое или кредитовое сальдо по счету 16 распределяют между выбывшей за месяц и оставшейся в использовании на конец месяца тарой по среднему проценту.

Средний процент рассчитывается по следующей формуле:

Средний процент = Сальдо на КМ по сч. 16 / (сумма выбывшей тары за месяц + остаток тары на КМ) * $100 \%$

Списание разниц, относящихся к выбывшей таре:

Дm 44 «Расходы на продажу» - Кm 16 «Отклонения в стоимости материальных ценностей»

После соответствующих записей по счету 16 «Отклонения в стоимости материальных ценностей» будет отраж ена разница, относящаяся к остатк у тары на конец месяца.

По тарным операциям могут быть как расходы и убытки, так и доходы.

Расходы включают в себя затраты на перевозку, погрузку, ремонт и т.д. Потери от бесхозяйственного отношения к таре (бой, лом) составляют убытк и. К доходам по таре относятся: стоимость тары, полученной от поставщиков бесплатно; превышение стоимости тары по сдаточным ценам над стоимостью тары по учетным ценам.

Расходы по таре учитываются на счеmе 44 «Расходы на продажу», а потери и доходы па счете 91 «Прочие доходы и расходы».

Поступление тары (вместе с товаром) от поставщика: 
Дm 41/3 «Тара под товаром и порожняя» - Km 60 «Расчеты с поставщиками и подрядчиками»

Дm 19 «НДС по приобретенным ценностям» - Кm 60 «Расчеты с поставщиками и подрядчиками»

Возврат тары поставщику или сдача ее соответствующим организациям:

Дm 60 «Расчеты с поставщиками и подрядчиками» - Km 41/3 «Тара под товаром и порожняя»

Списание недостач от операций с тарой (лом, бой):

Дm 94 «Недостачи и потери от порчи ценностей» - Кm 41/3 «Тара под товаром и порожняя»

Оприходование тары, выявленной по результатам инвентаризации, или тары, поступившей от поставщика без оплаты:

Дm 41/3 «Тара под товаром и порожняя» - Кm 91 «Прочие доходы и расходы»

Ремонт тары по договору силами сторонней организации отраж ается:

Дm 44 «Расходы на продажу» - Km 60 «Расчеты с поставщиками и подрядчиками»

Дm 19 «НДС по приобретенным ценностям» - Кm 60 «Расчеты с поставщиками и подрядчиками"

Тара может быть изготовлена предприятием самостоятельно, при этом ее учет проводится через счет 23 «Вспомогательные производства" в корреспонденции со счетами учета материалов, расчетов по оплате труда и другими. При оприходовании готовой тары на складе затраты на ее изготовление списываются с кредита счета 23 в дебет счета 41 «Товары» 
субсчет 3 «Тара под товаром и порожняя».

На предприятиях розничной торговли продажа населению порожней тары включается в розничный товарооборот.

Выручк а отраж ается следующим образом:

Дm 50 «Касса»- Кm 90/1 «Выручка»

Учетная стоимость тары списывается на счет реализации:

Дm 90/2 «Себестоимость продаж» - Кm 41/3 «Тара под товаром и порожняя»

Отражение в розничном товарообороте стоимости стеклянной посуды

Оборот розничной торговли показывается, включая стоимость стеклянной посуды, проданной населению с товаром, за вычетом стоимости возвращенной населением порожней стек лянной посуды, а так же вк лючая стоимость стеклопосуды, принятой от населения в обмен на товар.

Залоговая стоимость стеклопосуды выделяется в сопроводительных документах поставщиков отдельной строкой. Население, купив товар в такой стеклопосуде, имеет право после освобождения из-под товара сдать ее обратно в магазин и получить залоговую стоимость.

В розничных торговых предприятиях учет стеклопосуды, находящейся под товарами и порож ней, ведется с использованием счета 41/2 «Товары в розничной торговле» по залоговым ценам.

Оплата по залоговым ценам принятой от населения порожней стеклопосуды осуществляется специальными лицами (приемщиками), которым на эти цели выделяются под отчет 
денежные суммы. При этом на выданные подотчетные суммы составляется запись:

Дт 71 «Расчеты с подотчетными лицами» - Кm 50 «Касca»

На принятую приемщиками от населения порожнюю стек лопосуду выписывается накладная, на основании которой делается запись:

Дт 41 «Товары»- Кm 71 «Расчеты с подотчетными лицами»

Розничный товарооборот, отраженный на счете 90 «Продаж и» должен уменьшаться на стоимость стеклопосуды, реализованной в отчетном периоде населению с товаром, и увеличиваться на стоимость посуды, принятой от населения в обмен на товары.

Для осуществления корректировки розничного товарооборота на стоимость стеклопосуды необходимо вести учет движ ения стеклопосуды по различным ее видам:

- стоимость поступившей от поставщиков стеклопосуды под товарами;

- стоимость порожней стеклопосуды, возвращенной поставщикам;

- поступление стеклопосуды от населения в обмен на товары;

- поступление стек лопосуды от населения с оплатой через кассу магазина;

- поступление стеклопосуды от приемного пункта магазина; 
- поступление стеклопосуды от киоска, реализующего напитки с потреблением на месте или в разлив;

- поступление стеклопосуды от фрилиалов магазина.

Торговые предприятия должны корректировать товарооборот на стоимость посуды, проданной населению и не возвращенной им в торговую сеть.

\section{2. Вопросы для самоконтроля}

1. Какие виды тары выделяют в учете?

2. Система бухгалтерск их записей операций с тарой у поставщиков и покупателей?

3. Особенности отражения в розничном товарообороте стоимости стеклянной посуды.

4. Чем отличается тара-оборудование от тары, обращающейся по залоговым ценам?

5. К акими записями отражаются в учете затраты по изготовлению и ремонту тары? 


\section{ЛЕКЦИЯ 6.}

\section{УЧЕТ ТОВАРНЫХ ПОТЕРЬ, ЗАВЕСА ТАРЫ И ПЕРЕ- ОЦЕНКИ ТОВАРОВ}

План лекции.

1. Виды товарных потерь.

2. Исчисление и учет естественной убыли товаров.

3. Учет завеса тары.

4. Учет потерь при подготовке товаров к продаже.

5. Учет переоценки товаров.

6. Вопросы для самок онтроля.

\section{1. Виды товарных потерь}

Потери - это часть рационального и нерационального использования продукции из-за количественного уменьшения ее массы и ухудшения качества.

Потери можно классифицировать по нескольким признакам: по количественно-вещественному признаку, по отношению к нормам, по месту (стадии) возникновения, по виду, по субъекту возмещения.

По количественно-вещественному признаку потери подразделяются на количественные и потери от пониж ения качества.

По отношению к нормам выделяют нормируемые и не- 
нормируемые потери.

По месту или стадии возникновения выделяют потери при заготовке, перевозке, хранении, реализации, подготовке к продаже, фрасовке.

По виду выделяют: естественная убыль, потери, возникшие при подготовке к продаже, завес тары, потери в магазинах самообслуж ивания.

По субъекту возмещения потери классифицируют на: потери, возмещаемые материально ответственными лицами, транспортными организациями, поставщиками, торговыми организациями за счет издержек обращения, использования прибыли.

К нормируемым потерям относят естественную убыль товаров в весе или объеме, возникающую вследствие физических или химических процессов при нормальных условиях транспортировки, хранении, отпуске.

К ненормируемым потерям относятся бой, брак, порча товаров вследствие недобросовестности персонала при обращении с товарно-материальными ценностями.

Сокращение товарных потерь - это источник увеличения доходов торгового предприятия. Основными путями сокращения товарных потерь являются: улучшение материальнотехнической оснащенности, совершенствование товародвижения и хранения товаров, хорошо налаженный учет. Цель бухгалтерского учета состоит в устранении непроизводительные расходы. Для ее достижения необходимо проверять правильность документального офрормления товарных потерь, за- 
конность, своевременность, целесообразность их списания, своевременно выявлять неходовые, залежалые и недоброкачественные товары.

Товарные потери в торговых организациях выявляются, прежде всего, в момент проведения инвентаризации. Естественная убыль товаров списывается на издержки обращения, товарные потери сверх норм естественной убыли относятся на виновных лиц. Если виновники товарных потерь не установлены или во взыскании с виновных лиц отказано судом, то убытки от недостачи и порчи списывают на финансовые результаты. По товарным потерям, выявленным при приеме товаров от поставщика или транспортной организации предъявляются претензии поставщикам либо транспортной организации. Потери от стихийных бедствий являются убытками торговой организации.

\section{2.Исчисление и учет естественной убыли товаров}

Основным видом товарных потерь является естественная убыль товаров.

Естественная убыль - это потери при перевозке, хранении и реализации товарно-материальных ценностей, обусловленные их физико-химическ ими свойствами (усушка, утруска, утечка, испарения и т.п.). поскольку вышеуказанные потери возникают объективно, их нормируют, то есть устанавливают их предельные размеры (нормы).

Списание товарных потерь в пределах норм естественной 
убыли производится только в случаях, когда такие нормы утверждены в порядке, установленном Правительством РФ. В соответствии с Постановлением Правительства РФ от 12.11.2002 г. № 814 «О порядке утверждения норм естественной убыли при хранении и транспортировке материальнопроизводственных запасов» разработка и утверждение норм естественной убыли при хранении и транспортировке материально-производственных запасов осуществляются:

- М инистерством здравоохранения и социального развития РФ - по лекарственным, дезинфекционным, дезинсекционным и дератизационным средствам;

- Министерством промышленности и торговли РФ - по металлическ им рудам, сырью, используемому в металлургическом производстве, коксу, шлакам, металлам черным и цветным, древесине и продукции ее переработки, минеральным удобрениям, жидким криопродуктам, лакокрасочным материалам, химической и фармацевтическ ой продукции, продовольственным товарам в сфере торговли и общественного питания;

- М инистерством регионального развития РФ - по цементу, кварцевому песку и другим строительным материалам;

- М инистерством сельского хозяйства РФ - по продукции растениеводства сельского хозяйства, животноводства, микробиологической, мясной, молочной, мукомольно-крупяной и другой пищевой продукции, кроме рыбной, комбикормам и препаратам, применяемым в ветеринарии;

- Министерством энергетики РФ - по нефти, нефтепродуктам, каменному и бурому углям, торфу и горючим сланцам, 
альтернативным видам топлива;

- Федеральным агентством по рыболовству - по рыбной продук ции .

Разработанные федеральными органами исполнительной власти нормы естественной убыли, применяемые при перевозках всеми видами транспорта (кроме трубопроводного), утверж даются совместно с М инистерством транспорта РФ.

Нормы естественной убыли утверждаются по согласованию с М инистерством экономического развития РФ .

В настоящее время утверждены нормы естественной убыли при хранении (сливе, наливе) химической продукции (приказ М инпромторга РФ от 08.11.2010 № 1000).

В случае отсутствия утвержденных норм естественной убыли потери считаются сверх норм естественной убыли.

Нормы убыли могут применяться лишь в случаях выявления фактических недостач. Размер норм естественной убыли определяется на основании расчетов, которые составляются бухгалтерией после инвентаризации (с применением установленных нормативов) и утверждаются руководителем. Нормы естественной убыли являются предельными и естественная убыль списывается в фактических размерах, но не выше установленных норм.

Нормы естественной убыли товаров при перевозках железнодорожным, водным, автомобильным транспортом установлены в процентах к стоимости каждого вида товара, являются предельными и применяются только в том случае, если при приемке товаров будет обнаружена недостача товаров. 
предварительное списание недостачи не допускается.

Суммы естественной убыли определяются путем составления расчетов по каждому товару в отдельности по формуле:

$$
E У=((T+O T) \times H): 100 \text {, }
$$

где ЕУ - сумма естественной убыли,

Т - отпуск товаров за меж инвентаризационный период,

ОТ - остаток товаров по счету 41/1 на конец инвентаризационного периода,

Н - норма убыли с учетом срока хранения товара.

Для применения процента естественной убыли нужно определить срок хранения товара. На складах товар может учитываться партионным или сортовым способом.

При партионном способе учета товара каждая партия товара хранится отдельно. Естественная убыль исчисляется по фактическим срокам их хранения на складах, исходя из начальной даты поступления каждого товара, даты отпуска и даты инвентаризации. Срок хранения определяется по партионной карте.

При сортовом способе хранения каждый вновь приобретенный товар определенного сорта присоединяется к ранее поступившему товару того же наименования и сорта, товары хранятся по сортам. Для определения среднего срока хранения товара, сначала рассчитывают среднесуточный остаток товара. Для этого суммируют остатки товаров за каждый день хранения в инвентаризационный период и полученную сумму делят на количество дней в этом периоде. Следующий расчетный показатель - однодневный оборот, который определяется 
делением оборота товаров за меж инвентаризационный период на число дней в этом периоде. средний срок хранения товара определяется делением среднесуточного остатка товаров на однодневный оборот.

Нормы естественной убыли не применяются к штучным товарам, к товарам, списанным по актам о порче, бое, ломе, а также по товарам, принятым и отпущенным без взвешивания (счетом единиц или по массе, указанной в таре). Потери товаров вследствие естественной убыли рассчитываются только по реализованным товарам.

В отличие от оптовой торговли нормы естественной убыли в розничных организациях установлены без учета срока их хранения.

Естественная убыль в розничной торговле исчисляется только с реализованных товаров (при наличии норм). Оборот по реализации отдельных видов товаров в розничной торговле непосредственно выявить, как правило, невозможно, поскольку аналитический учет товаров по видам обычно не ведется. Поэтому оборот по реализации того или иного товара за меж инвентаризационный период определяется расчетным путем на основе показателей товарного баланса, при этом к имеющемуся остатку товара на начало межинвентаризационного периода прибавляют поступления товара за данный период и корректируют на выбытие товара за меж инвентаризационный период и остаток товара на конец данного периода.

При этом:

- остаток товара на начало меж инвентаризационного пе- 
риода берется по данным предыдущей инвентаризации;

- количество поступившего товара за межинвентаризационный период определяется по данным приходных докуменTOB;

- количество выбывшего товара за меж инвентаризационный период отслеживается на основании данных расходных документов;

- остаток соответствующего товара на конец межинвентаризационного периода берется по данным последней инвентаризации.

Определив оборот по реализации того или иного товара за меж инвентаризационный период и умножив его на норму естественной убыли, можно получить сумму естественной убыли по данному товару. Рассчитав сумму естественной убыли по каждому товару, можно определить общую сумму естественной убыли по всем товарам, реализованным за межинвентаризационный период. Данный расчет имеет смысл при наличии соответствующих норм.

Отраж ена недостача товаров в пределах норм естественной убыли:

Дт 94 «Недостачи и потери от порчи ценностей» - Кm 41 «Товары»

При списании недостачи в пределах норм естественной убыли делается запись:

Дm 44 «Расходы на продажу» - Km 94 «Недостачи и потери от порчи ценностей»

Расчет потерь в пределах норм естественной убыли про- 
изводится по каждой группе товаров. С согласия материально ответственного лица для списания потерь в пределах норм естественной убыли могут быть применены средние нормы. Потери товаров вследствие естественной убыли списываются в том месяце, в котором проводилась инвентаризация на издержки обращения. В связи с тем, что инвентаризация проводится не еж емесячно, и выявленные потери относятся ко всему проверяемому периоду, для равномерного списания потерь от естественной убыли в издержки каждого месяца в меж инвентаризационном периоде целесообразно создавать специальный резерв на покрытие этих потерь. Начисление резерва производится за счет издержек обращения в плановом размеpe.

Начисление резерва на списание потерь в пределах норм естественной убыли на счетах бухгалтерского чета отражается:

Дm 44 «Расходы на продажу»- Кm 96 «Резервы предстоящих расходов»

После проведения инвентаризации недостача товаров в пределах норм естественной убыли списывается за счет начисленного резерва.

Списание потерь товаров за счет резерва отражается проводкой:

Дт 96«Резервы предстоящих расходов»- Кm 94 «Недостачи и потери от порчи ценностей»

Если фактическая сумма недостачи от естественной убыли будет не равна созданному резерву, то на недостающую 
сумму доначисляется резерв или сторнируется излишек запиCью:

Дm 44 «Расходы на продажу» - Km 96 «Резервы предстоящих расходов»

\section{3. Учетзавеса пары}

При поступлении продовольственных товаров в таре их чистая масса определяется вычитанием из массы брутто условной массы тары (по маркировке). После продажи этих товаров освобож денную тару взвешивают. Фактическая масса тары после продажи товаров может оказаться больше условной массы по маркировке, которая была принята при оприходовании товара.

Необходимо учитывать потери и излишки, которые могут возникнуть вследствие завеса тары, - разницы между фактической массой порожней тары и ее массой по маркировке. Наличие завеса тары означает, что товара поступило меньше, чем оприходовано. О фак те недостачи составляется акт о завесе тары, который вместе с товарным отчетом передается в бухгалтерию. При этом мож ет быть составлена проводка:

Дm 76/2 «Расчеты по претензиям» - Кm 41 «Товары»

При списании завеса тары за счет поставщика ему долж ны быть направлены претензия и акт выявления завеса тары. В остальных случаях завес тары списывают на виновных лиц:

Дm 73/2 «Расчеты по возмещению материального ущерба»- Кm 41 «Товары» 
Акт на завес тары составляется в срок, предусмотренный договором с поставщиком, но не позднее 10 дней после ее освобождения.

Выявленная при инвентаризации недостача товаров вследствие завеса тары списывается с материально ответственного лица при условии, что недостающая сумма превышает естественную убыль (при наличии норм).

Завес тары списывают в зависимости от условий договора с поставщиком. При списании за счет поставщика ему направляют претензионное письмо вместе с актом о завесе тары.

Если предъявить претензию поставщику невозможно, потери товаров от завеса тары относят на виновных лиц. Лишь в исключительных случаях (когда установить виновных нельзя) потери от завеса тары могут быть списаны за счет торговой организации.

По некоторым товарам поставщики могут предоставлять магазинам специальную скидку на завес тары. При поступлении товаров эту скидку записывают на кредит счета 42 «Tорговая наценка» (на аналитический счет "Скидка на завес тары»). По таким товарам акты на завес тары не составляются и претензии поставщикам не предъявляют, а фак тический завес тары списывают за счет предоставленной скидки.

Завес тары за счет ск идк и списывают только в том случае, если при инвентаризации будет выявлена недостача товаров сверх норм естественной убыли. Первоначально списывают сумму полученной скидки на завес тары (за вычетом скидки, 
относящейся к остатку затаренных товаров), а затем в соответствующей сумме естественную убыль.

После решения руководителя организации о порядке списания завеса тары на стоимость товаров по покупным ценам кредитуется счет 94 «Недостачи и потери от порчи иенностей» и дебетуются счета 76/2 «Расчеты по претензиям» при списании за счет поставщика; 42 «Торговая наценка» субсчет «Скидка на завес тары» - при списании за счет специальной скидки.

Если товары учитывают по продажным ценам, то одновременно на сумму торговой надбавки, относящейся к завесу тары, делается запись:

Дт 98 «Доходы будущих периодов» - Кm 94«Недостачи и потери от порчи ценностей»

При списании потерь от завеса тары за счет виновного лица на стоимость товаров по учетным ценам:

Дm 73/2 «Расчеты по возмещению материального ущерба» - Кm 94 «Недостачи и потери от порчи ценностей»

Для предотвращения повторных завесов тару, имеющую разницу между фактической массой и маркировочной, помечают.

\section{4. Учет потерь при подготовке товаров к продаже}

В соответствии с Правилами продажи отдельных видов товаров поступающие в торговый зал товары тщательно проверяются по качеству и рассортировываются. Товары до их 
подачи в торговый зал или иное место продажи должны быть освобождены от тары, оберточных и увязочных материалов, металлических клипс. Загрязненные поверхности или части товара должны быть удалены. Продавец обязан также произвести проверку качества товаров (по внешним признакам), наличия на них необходимой документации и информации, осуществить отбраковку и сортировку товаров. При этом, естественно, образуются отходы, подлеж ащие списанию .

Ряд товаров возможно приходовать за минусом отходов по установленным нормам (колбасные изделия без веревок, птица без упаковки). В этом случае сумму отходов рассчитывают на документах на поступление товара и списывают за счет дополнительной скидки поставщика или за счет торговой организации (в зависимости от условий, определяемых в договоре). Вместе с тем, некоторые отходы (например, кости) реализуются по устанавливаемым торговым предприятием ценам. Ряд отходов сдается в переработку (зачистки жиров) специальным организациям, которые оплачивают их по договорным ценам. Зачистк и и крошка списываются на основании накладных, по которым они сдаются в переработку.

Предприятия могут уменьшать сумму поступивших товаров на величину нормируемых потерь с отнесением отходов на счет поставщика или за свой счет. При этом часть потерь мож ет быть возмещена при реализации отходов.

Списание потерь при подготовке товаров к продаже должно производиться за счет издержек обращения и отражаться по статье «Потери товаров и технологическ ие отходы». 
К ним относятся нормируемые отходы, образующиеся при подготовке к розничной продаже колбас, мясокопченностей и рыбы чистой массы; потери от зачистки сливочного масла, крошения карамели обсыпной и сахара-рафинада. При отсутствии норм потери списываются за счет прибыли предприятия.

Отражение в учете потерь при подготовке товаров к продаже может быть отражено проводкой на примере списания зачисток жира:

Дm 62 «Расчеты с покупателями и заказчиками» - на продажную стоимость зачисток

Дт 98 «Доходы будущих периодов» - на сумму торговой надбавки на зачистки

Дm 44 «Расходы на продажу» - на разность между покупной и продажной стоимостью зачисток

Кm 94 «Недостачи и потери от порчи ценностей» - на стоимость зачисток по учетным ценам.

\section{5. Учетпереоценки поваров}

Организации розничной торговли могут производить переоценку (изменение цен) товаров в случаях:

- изменения конъюнктуры рынка;

- изменения спроса на товары;

- ухудшения качественных характеристик товаров (устаревание моделей и фасонов, ухудшение товарного вида, частичная потеря свойств); 
- морального устаревания этих ценностей.

Переоценка товаров может происходить в сторону снижения цен (уценка) и в сторону повышения (дооценка). Продажная цена товаров изменяется на основании приказа руководителя организации.

Суммы уценки (дооценки) представляют собой разницу между стоимостью остатков товаров по прежним и вновь установленным продажным ценам.

Переоценка отражается на счетах бухгалтерского учета, если в организации учет ведется по продаж ным ценам.

В случае уценки товаров в пределах торговой наценки изменяется розничная цена. Значит, сумма уценки уменьшит торговую наценку на товары и снизит их розничную цену. При уценке товаров по продажным ценам на сумму, превышающую торговую наценку, изменяется их учетная цена.

На сумму уценки товара в пределах торговой наценки делается сторнировочная запись:

Дm 41/2 «Товары в розничной торговле» - Кm 42 «Торговая наценка»

На сумму уценки товара, превышающую величину торговой наценки:

Дт 91 «Прочие доходы и расходы» - Кm 41/2 «Товары в розничной торговле»

Дооценка товаров по розничным ценам производится по мере необходимости в соответствии с приказом руководителя:

Дm 41/2 «Товары в розничной торговле» - Кm 42 «Торговая наценка» 
Если в учетной политике организации предусмотрено использование оценки товаров по покупным ценам, данные уценки в бухгалтерском учете не фиксируются. При дооценке товаров, учитываемых по покупным ценам, организация, основываясь на приказе руководителя, составляет новые прейскуранты, офрормляет новые ценники. В бухгалтерском учете товаров по покупным ценам дооценка не отражается, поскольку цена, по которой товары числятся в текущем учете, не изменяется.

Отражение в бухгалтерской отчетности материальнопроизводственных запасов по текущей рыночной стоимости, если она ниже стоимости материальных ценностей, принятой к бухгалтерскому учету, влечет за собой образование резервов под снижение стоимости материальных ценностей за счет прочих расходов, при этом на указанную разность составляется запись:

Дт 91 «Прочие доходы и расходы»-Кm 14 «Резервы под снижение стоимости материальных ценностей»

В начале периода, следующего за периодом, в котором произведена запись, зарезервированная сумма восстанавливается записью:

Дт 14 «Резервы под снижение стоимости материальных ценностей» - Кm 91 «Прочие доходы и расходы»

В бухгалтерск ом балансе сумма резервов отдельно не отражается, а учитывается по соответствующим строкам, уменьшая стоимость материальных ценностей. 


\section{6. Вопросы для самок онтроля}

1. Назовите виды товарных потерь.

2. Что такое естественная убыль? Каков порядок ее списания в учете?

3. завес тары и отраж ение его в учете.

4. Какие потери могут возникнуть при подготовке товаров к продаже?

5. В каких случаях производится переоценка?

6. Как отражаются в учете результаты переоценки товаров?

7. Нормируемые и ненормируемые потери. 


\section{ЛЕКЦИЯ 7.}

\section{ИНВЕНТАРИЗАЦИЯ ТОВАРОВ И ТАРЫ}

План лекции.

1. Порядок проведения инвентаризации.

2. Отраж ение в учете результатов инвентаризации.

3. Вопросы для самоконтроля.

\section{1. Порядок проведения инвентаризации}

Для обеспечения достоверности данных бухгалтерского учета и бухгалтерской отчетности торговая организация обязана проводить инвентаризации обязательств и имущества, в том числе товаров и тары. В ходе инвентаризации проверяются и документально подтверждаются их наличие, состояние и оценка.

Порядок проведения инвентаризаций определяется Методическими указаниями по инвентаризации имущества и фринансовых обязательств, утвержденными приказом М инфина России от 13.06.95 г. №49.

Основными целями инвентаризации являются:

- выявление фрак тическ ого наличия имущества;

- сопоставление фрактического наличия имущества с дан ными бухгалтерского учета;

- проверка полноты отраж ения в учете обязательств. 
Проведение инвентаризации обязательно:

- перед составлением годовой бухгалтерск ой отчетности;

- при смене материально ответственных лиц;

- при выявлении фактов хищения, злоупотреблении или порчи имущества;

- в случае стихийного бедствия, пожара или других чрезвычайных ситуаций, вызванных эк стремальными условиями;

- при реорганизации или ликвидации организации;

- в других случаях, предусмотренных зак онодательством.

Количество инвентаризаций в отчетном году, даты их проведения, перечень проверяемых запасов определяется руководителем организации.

По результатам инвентаризаций принимаются соответствующие решения по устранению недостатков в хранении и учете запасов и возмещению материального ущерба.

Для проведения инвентаризации в торговой организации создается постоянно действующая инвентаризационная комиссия. При большом объеме работ для одновременного проведения инвентаризации имущества и финансовых обязательств создаются рабочие инвентаризационные комиссии.

Для документального оформления проведения инвентаризации и отражения ее результатов в учете применяются типовые формы первичной учетной документации.

Приказом руководителя организации о проведении инвентаризации (ф. № ИНВ-22) утверждается персональный состав инвентаризационной комиссии, перечень инвентаризируемого имущества, даты начала и окончания инвентариза- 
ции.

До начала работы комиссия проверяет наличие оформленных на момент инвентаризации последних отчетов о движении материальных ценностей и денежных средств или соответствующих приходных и расходных документов. Материально ответственные лица подтверждают (дают расписку) полноту представления инвентаризационной комиссии всех приходных и расходных документов на имущество и достоверность ук азанных в них сведений.

Председатель комиссии визирует все приходные и расходные документы, приложенные к отчету или реестрам, на основании которых в бухгалтерии определяются учетные остатки имущества к началу инвентаризации.

Учетные и фрактические остатки имущества, а также выявленные при инвентаризации количественные и суммовые расхождения между фактическ им наличием имущества и данными бухгалтерского учета заносятся в инвентаризационные описи или акты инвентаризации (ф. № ИНВ-1 - ИНВ-17).

Акты обмеров, технические расчеты, ведомости отвесов, оформленные в соответствии с принятым организацией порядком, прилагаются к инвентаризационным описям и актам инвентаризации, подписываются всеми членами комиссии и материально ответственными лицами, обязательно присутствующими при проверке, и сдаются в бухгалтерию для отражения результатов инвентаризации на счетах бухгалтерского учета.

В бухгалтерии фактические данные, полученные в про- 
цессе инвентаризации, сверяются с показателями бухгалтерского учета. В случае выявления расхождений суммы отклонений заносятся в сличительные ведомости (ф. № ИНВ-18, № ИНВ-19). В конце отчетного года результаты всех проведенных инвентаризаций обобщаются в ведомости учета результатов, выявленных инвентаризацией (ф. № ИНВ-26).

По окончании инвентаризации в соответствии с распоряжением руководителя организации могут производиться контрольные проверки правильности проведения инвентаризации, результаты которых оформляются актом (ф. № ИНВ24). Акты о контрольной проверке регистрируются в журнале учета контрольных проверок правильности проведения инвентаризации (ф. № ИНВ-25).

Инвентаризация в розничной торговле проводится в сроки, установленные руководителем торгового предприятия, но не реже двух раз в год.

Одновременно с проведением инвентаризации в магазине она осуществляется и в прикрепленных к нему палатках, киосках и пр. Если магазин имеет кладовые отделы и секции, филиалы с раздельной материальной ответственностью, то инвентаризацию в них можно проводить отдельно, без закрытия всего магазина.

Перед началом инвентаризации магазин закрывают, обслуж ивают только покупателей, находящихся в торговом зале. При этом операции с товарно-материальными ценностями прекращаются. Все подсобные помещения пломбируют. Вместе с тем с согласия руководителя и представителя комиссии 
могут быть отпущены до начала инвентаризации товары первой необходимости для продажи с лотков или в мелкорозничной сети.

Инвентаризация на розничных торговых предприятиях начинается с проверки денежных средств в кассе, а при ее отсутствии - на руках у продавцов. Такую проверку оформляют актом снятия остатков кассы в магазине и фиксируют на титульном листе инвентаризационной описи. Кассир на момент инвентаризации составляет кассовый отчет и передает его для проверки и визирования документов председателю комиссии. Определяют результат по кассе (недостачу, излишек), который отраж ают в акте.

Председатель комиссии и счетный работник проверяют и визируют товарные отчеты и все приходные и расходные документы, приложенные к нему, и ставят штамп «До инвентаризации».

Комиссия начинает инвентаризацию с подсобных помещений магазина. В это время в торговом зале члены бригады материально ответственных лиц подбирают и группируют товары по наименованиям, сортам, артикулам, размерам и ценам в порядке, удобном для пересчета, перемеривания. Подготовка товаров к пересчету и перевешиванию производится в присутствии членов комиссии, которые перевешивают, пересчитывают, перемеривают все товары. Нераспакованные товары распаковывают. Если распаковка товара может вызвать понижение его качества, то массу товара определяют по трафарету (по массе брутто) с выборочной проверкой ряда товарных 
мест. Установленное комиссией фактическое количество товара отражается в инвентаризационной описи - акте.

Товары, имеющие отходы при их подготовке к продаже (колбасные изделия, мясокопчености, битая птица), записываются в инвентаризационную опись с пометкой «очищенные» или «неочищенные».

Отдельными описями оформляют выявленные при инвентаризации неходовые и залежалые товары, а также тару. Бой, брак, порчу ак тируют в обычном порядке. Предварительный результат инвентаризации определяют на месте сразу же после ее окончания, сопоставив остатки товаров и тары по товарному отчету с инвентаризационной описью. При выявлении больших расхождений комиссия обязана взять письменное объяснение с материально ответственных лиц, опломбировать магазин и сообщить об этом руководителю торгового предприятия.

Окончательные результаты инвентаризации определяются в бухгалтерии и оформляются сличительной ведомостью результатов инвентаризации товаров, материалов, тары и денежных средств в торговле (в мелкорозничной сети - не позднее следующего дня после ее окончания; по магазинам - в трехдневный срок ).

При выявлении недостачи рассчитывают и списывают по нормам естественную убыль (при наличии норм) и потери (в пределах фактическ их недостач).

Недостача, не перекрытая суммой нормируемых потерь, подлеж ит взысканию с виновных лиц в установленном поряд- 
ке. Излишки товаров и тары приходуются с отнесением на доходы предприятия. Результат инвентаризации тары оформляют составлением сличительной ведомости в количественностоимостном выраж ении по каждому виду тары в отдельности.

Со сличительной ведомостью бухгалтер обязан ознакомить материально ответственное лицо под расписку в ведомости.

По распоряжению руководителя выявленная недостача товаров и тары сверх норм естественной убыли в размере, не превышающем среднего месячного заработка работника (каждого члена бригады при коллективной ответственности), взыск ивается путем удержания ее из заработной платы работника. Ущерб, превышающий средний месячный заработок работника, взыск ивается путем подачи иска в суд, если работник отказался погасить его добровольно.

\section{2. Отраж ение в учете результатов инвентаризации}

Результаты инвентаризации отражаются в учете и отчетности того месяца, в котором была закончена инвентаризация, а по годовой инвентаризации - в годовом бухгалтерском отчете.

По результатам инвентаризации составляются бухгалтерские проводки. Выявленные при инвентаризации излишки товаров приходуются по рыночным ценам и относятся в доход предприятия:

Дm 41 «Товары» - Кт 91 «Прочие доходы и расходы» 
Суммы выявленных товарных потерь (недостач товаров и потерь от порчи) отраж аются записью:

Дт 94 «Недостачи и потери от порчи иенностей» - Km 41 «Товары»

Недостачи могут быть списаны в дальнейшем за счет различных источников в зависимости от причин их возникновения: на расходы на продажу, на виновных лиц, на финансовые результаты.

Недостачи в пределах норм естественной убыли (при их наличии) относятся за счет начисленного ранее резерва (если он имеет место), что фрик сируется записью:

Дт 96 «Резервы предстоящих расходов»- Кm 94 «Недостачи и потери от порчи ценностей».

В организации розничной торговли, ведущей учет товаров по продажным ценам, списание с материально ответственного лица недостач товаров в пределах установленных норм естественной убыли производится по продажным ценам, а на расходы на продажу эти недостачи относятся по цене приобретения товара. При этом сумма торговой наценки, приходящаяся на недостающие товары, сторнируется:

Дт 94 «Недостачи и потери от порчи ченностей» - Km 42 «Торговая наценка».

Списание недостач на расходы на продажу отраж ается:

Дm 44 «Расходы на продажу» - Km 94 «Недостачи и потери от порчи ченностей».

Сумма недостачи, выявленная при инвентаризации имущества, превышающая нормы естественной убыли, относится 
на виновное лицо если:

- виновное лицо несет полную материальную ответствен ность за сохранность товарно-материальных активов;

- работник признан виновным по решению суда.

Порядок возмещения ущерба виновным лицом определяется Трудовым кодексом РФ. В соответствии со ст. 238 ТК РФ работник обязан возместить работодателю причиненный ему прямой действительный ущерб. Под прямым действительным ущербом понимается реальное уменьшение наличного имущества работодателя или ухудшение состояния указанного имущества, а также необходимость для работодателя произвести затраты либо излишние выплаты на приобретение или восстановление имущества.

Размер ущерба, причиненного организации при утрате и порче имущества, определяется по фак тическим потерям, исчисляемым исходя из рыночных цен, действующих в данной местности на день причинения ущерба, но не ниже стоимости имущества по данным бухгалтерского учета.

Сверхнормативная убыль относится за счет виновных лиц:

Дm 73/2 «Расчеты по возмещению материального ущерба» - Km 94 «Недостачи и потери от порчи ценностей»

При отсутствии виновных лиц недостачи сверх норм фиксируются записью:

Дm 91 «Прочие доходы и расходы» - Km 94 «Недостачи и потери от порчи ценностей»

При инвентаризации в комиссионной торговле размер 
понесенного ущерба в результате хищения или недостачи товаров определяется по продаж ным ценам.

Списание суммы недостач товаров в комиссионном магазине, выявленной в результате инвентаризации, отражается записью:

Kт 004 «Товары, принятые на комиссию»

Сумма задолженности комитенту (сумма, указанная в договоре комиссии) выплачивается комитенту и отраж ается следующей проводкой:

Дт 94 «Недостачи и потери от порчи ченностей» - Km 76 «Расчеты с разными дебиторами и кредиторами»

На разницу между стоимостью товаров по продажным ценам и суммой, подлежащей выплате комитенту, при выявленной недостаче составляется проводка:

Дm 94 «Недостачи и потери от порчи ценностей» - Km 98/4 «Разница между суммой, подлежащей взысканию с виновных лиц, и балансовой стоимостью по недостачам ценностей»

Списание недостачи товаров за счет виновных лиц отраж ается записью на сумму недостачи по продаж ным ценам:

Дm 73/2 «Расчеты по возмещению материального ущерба» - Km 94 «Недостачи и потери от порчи ценностей»

Сумма поступивших денег в кассу от виновного лица на сумму недостачи товаров по продажным ценам фиксируется проводкой:

Дm 50 «Касса» - Km 73/2 «Расчеты по возмещению материального ущерба»

При этом разница меж ду стоимостью товара, оплаченной 
виновным лицом, и суммой, выплаченной комитенту, отражается записью:

Дm 98/4 «Разница между суммой, подлежащей взысканию с виновных лиц, и балансовой стоимостью по недостачам ценностей» - Km 91 «Прочие доходы и расходы»

Недостачи ценностей, выявленные в отчетном году, но относящиеся к прошлым отчетным периодам (признанные материально ответственными лицами или на которые имеются решения суда о взыскании с виновных лиц) отраж аются:

Дm 73/2 «Расчеты по возмещению материального ущерба» - Km 94 «Недостачи и потери от порчи ценностей»

Одновременно эти суммы отражаются:

Дm 94 «Недостачи и потери от порчи ченностей» - Km 98/3 «Предстоящие поступления задолженности по недостачам, выявленным за прошлые годы».

По мере погашения задолженности суммы, отраж енные на счете 98/3 списываются:

Дт 98/3 «Предстоящие поступления задолженности по недостачам, выявленным за прошлые годы» - Km 91 «Прочие доходы и расходы»

Суммы потерь при отсутствии конкретных виновных лиц, а также по недостачам, во взыскании которых отказано судом вследствие необоснованности исков, включаются в состав прочих расходов организации:

Дm 91 «Прочие доходы и расходы» - Km 94 «Недостачи u потери от порчи ценностей»

Потери товаров в результате стихийных бедствий, пожа- 
ров, аварий и других чрезвычайных ситуаций списываются:

Дт 91 «Прочие доходы и расходы» - Km 94 «Недостачи и потери от порчи ценностей»

Страховые возмещения, поступающие в качестве компенсации потерь от стихийных бедствий, пожаров и других чрезвычайных ситуаций, учитываются в составе прочих доходов по кредиту счета 91 «Прочие доходы и расходы».

\section{3. Вопросы для самоконтроля}

1. Каковы основные цели проведения инвентаризации товаров и тары?

2. В каких случаях проведение инвентаризации обязательно?

3. Какими документами оформляются результаты инвентаризации?

4. К ак ими записями в бухгалтерск ом учете оформляются излишки товаров, выявленные при инвентаризации?

5. За счет как их источников могут быть списаны недостачи, выявленные при инвентаризации?

6. Порядок возмещения ущерба виновным лицом. 


\section{ЛЕКЦИЯ 8.}

\section{УЧЕТ ОПТОВОЙ РЕАЛИЗАЦИИ ТОВАРОВ}

\section{План лекции.}

1. Порядок определения стоимости реализованных товаров.

2. Документальное оформление продажи товаров со складов.

3. Учет продажи товаров.

4. Учет реализации по договору комиссии.

5. Вопросы для самоконтроля.

\section{1. Порядок определения \\ стоимости реализованньх товаров}

Методическими указаниями по учету материальнопроизводственных запасов оценку реализованных товаров в оптовой торговле разрешено производить одним из следующих способов:

- по себестоимости каждой единицы;

- по средней себестоимости;

- способом ФИФО.

При списании (отпуске) по себестоимости каждой единицы могут применяться два варианта исчисления себестоимости единицы запаса:

- включая все расходы, связанные с приобретением запаca; 
- включая только стоимость запаса по договорной цене (упрощенный вариант).

Применение упрощенного варианта допускается при отсутствии возможности непосредственного отнесения транспортно-заготовительных расходов (ТЗР) на себестоимость товаров (например, при централизованной поставке).

В этом случае отклонение (разница меж ду фрак тическ ими расходами по приобретению товаров и его договорной ценой) распределяется пропорционально стоимости списанных (отпущенных) товаров, исчисленной в договорных ценах.

Оценку отгруженных товаров по себестоимости каждой единицы запаса применяют в случае, если используемые запасы не могут обычным образом заменять друг друга и подлежат особому учету (например, драгоценные металлы).

При списании (отпуске) товаров, оцениваемых организацией по средней себестоимости, последняя определяется по каж дой группе запасов как частное от деления общей себестоимости группы запасов на их количество, ск ладывающееся соответственно из себестоимости и количества по остатку товаров на начало месяца и по поступившим запасам в этом месяце:

$$
C \Phi C=(\mathrm{CO}+\mathrm{C3}):(K \mathrm{KO}+K 3), \text { где }
$$

СФС - средняя фрак тическая себестоимость за месяц;

СО - фрактическая себестоимость остатка товаров на начало месяца;

C3 - себестоимость поступивших товаров за месяц;

КО - остаток товаров на начало месяца; 
К 3 - количество поступивших товаров.

Метод ФИФО предполагает, что сначала должны списываться партии товаров, которые поступили в организацию раньше всего. Стоимость реализованных товаров данным методом можно определять двумя способами. Во-первых, отслеживая расход каждой партии товаров. Во-вторых, определив стоимость неизрасходованных поставок и вычтя ее из общей стоимости остатков на конец и всех поступлений.

Вне зависимости от избранного способа определения себестоимости реализованных товаров при их продаже производится бухгалтерская запись:

Дт 90 «Продажи»--Кт 41 «Товары»

\section{2. Документальное оформление продаж и товаров со ск ладов}

Продажа товаров организациями оптовой торговли осуществляется на основании договоров с покупателями и заказчиками .

При продаже товаров со склада торговый отдел оптовой организации, на основании заказов - заявок покупателей (после их регистрации в специальном ж урнале) или на основании условий договора, дает указание ск ладам на отбор товаров.

Порядок отпуска товаров со ск лада определяется условиями договора, в котором важное место уделено способу доставки товаров. от способа доставки товаров зависит порядок док ументального оформления продаж и товаров со ск ладов.

Основные способы доставк и товаров: 
- централизованная доставка товаров покупателям поставщик ом;

- самостоятельный вывоз организацией-покупателем товаров со ск лада поставщика;

- доставка товаров транспортными организациями (автомобильный, ж елезнодорож ный, водный транспорт).

При централизованной доставке товаров оптовые организации используют свой автомобильный транспорт, либо зак лючают договор на транспортное обслуж ивание со специализированными организациями.

На отобранный согласно договору или заказу товар завскладом выдает экспедитору или шоферу, ответственному за доставку товаров, три экземпляра счетов или счетов-фактур, выписанных на покупателей, и три экземпляра товарнотранспортных накладных. Четвертые экземпляры этих документов с распиской ответственного за доставку лица в получении груза остаются в оптовой организации. В оставшемся эк земпляре указывается номер автомашины, путевого листа, фамилия шофера.

По прибытии машины с товаров в пункт назначения (магазин) экспедитор или шофер проверяет наличие доверенности на право получения товара работниками торговой организации. Покупатель проверяет целость тары и принимает товары, а на счетах или счетах-фрактурах проставляются номер и дата доверенности, сумма принятых товаров и тары, подпись лица, принявшего груз, печать торговой организациипокупателя. Получение груза подтверж дается такж е подписью 
представителя организации-покупателя и печатью на товарнотранспортных накладных. Два экземпляра сопроводительных док ументов (счета или счета-фрактуры и товарно-транспортной накладной) после соответствующего оформления возвращаются лицу, ответственному за доставку товаров.

Если при приемке грузов покупателем были выявлены расхождения фактически имеющихся товаров с данными сопроводительных документов, то им составляется Акт об установленном расхождении по количеству и качеству при приемке товарно-материальных ценностей (ф. № ТОРГ-2). Ш офер или экспедитор получает один экземпляр этого акта, а на сопроводительных документах делается отметка о составлении акта и указывается сумма фактически принятых товаров.

По возвращении в оптовую организацию лицо, ответственное за доставку груза, передает завскладом два эк земпляра счета или счета-фактуры, один экземпляр товарнотранспортной накладной и, в случае составления, один эк земпляр Акта об установленном расхождении по количеству и качеству при приемке товарно-материальных ценностей. Последний эк земпляр товарно-транспортной накладной, вместе с путевым листом, шофер сдает в бухгалтерию оптовой организации.

При самовывозе лицо, уполномоченное получить товар, представляет доверенность. Представитель пок упателя производит прием товаров по количеству и качеству непосредственно в организации оптовой торговли. На отпущенный товар выписывается счет или счет-фрактура в четырех экземпля- 
рах. Два эк земпляра документов с подписями получателя товара и доверенностью наполучение товара остаются в оптовой организации, а два других - выдаются на руки представителю пок упателя.

При отгрузке товаров покупателям по железной дороге, водным путем или автотранспортом груз сдается представителям транспортной организации по накладной, заполняемой грузоотправителем. Нак ладная сопровождает груз на всем пути следования и выдается представителю организациипокупателя в пункте назначения вместе с товаром. Ответственность за сохранность грузов в пути в полном объеме несет транспортная организация.

В оптовой торговле возможен отпуск товаров розничным и другим организациям, находящимся на общем балансе с оптовой организацией. Такой отпуск товаров называется внутренним перемещением товаров и оформляется накладной.

\section{3. Учет продаж и товаров}

Реализация товаров в оптовой торговле регулируется договорами купли-продаж и, поставки, мены, комиссии, перевозки и т.д.

По форме товародвиж ения оптовая продажа подразделяется на продажу со складов (складск ой оборот) и транзитом (с участием оптовой организации в расчетах и без).

Кроме того, порядок документального оформления про- 
даж и товаров зависит от способа отпуска товаров покупателю: со ск лада поставщика, путем отправления по железной дороге или водным (воздушным) транспортом, централизованной доставк ой автотранспортом, на ск ладе пок упателя.

По договору поставки продавец обязуется передать в обусловленный срок покупателю для использования в предпринимательской деятельности или в иных целях, не связанных с личным, семейным, домашним и иным подобным использованием.

Момент перехода права собственности на товары определяется условиями договора, заключенного меж ду поставщиком и покупателем. По договорам поставки, как правило, переход права собственности происходит в момент отгрузки товаров и передачи товаросопроводительных документов.

Суммы, подлежащие оплате покупателем, продавец учитывает по дебету счета 62 «Расчеты с покупателями и заказчиками .

Бухгалтерский учет продажи товаров осуществляется на счете 90 «Продажи» с использованием соответствующих субсчетов: 90/1 «Выручка», 90/2 «Себестоимость продаж», 90/3 «НДС», 90/4 «Акцизы», 90/9 «Прибыль/ убыток от продаж».

В оптовой торговле при отгрузке товаров на основании предъявленных покупателю расчетных документов отражается выручка от продажи:

Дm 62 «Расчеты с покупателями и заказчиками»- Km 90/1 «Выручка»

Производится начисление суммы НДС на основании сче- 
та-фрак туры:

Дт 90/3 «НДС»- Кm 68 «Расчеты по налогам и сборам»

При списании проданных товаров с материально ответственных лиц по покупной стоимости:

Дm 90/2 «Себестоимость продаж»- Кm 41/1 «Товары на складах»

Отнесены за счет покупателя согласно договору транспортные расходы:

Дm 62 «Расчеты с покупателями и заказчиками» - Km 76 «Расчеты с разными дебиторами и кредиторами»

Оплачены транспортные расходы с расчетного счета:

Дm 76 «Расчеты с разными дебиторами и кредиторами» Km 51 «Расчетные счета»

Списаны расходы, относящиеся к проданным товарам:

Дm 90/2 «Себестоимость продаж»- Кm 44 «Расходы на продажу»

На счете 90 «Продажи» в конце месяца выявляют финансовый результат от продаж. Записи по счету 90/1,2,3,4 ведутся нак опительно в течение отчетного года. Еж емесячно путем сопоставления совок упного дебетового оборота по счету 90/2,3,4 и кредитового оборота по счету 90/1 определяют финансовый результат от продаж за отчетный месяц. Этот финансовый результат еж емесячно (заключительными оборотами) списывают с 90/9 на счет 99 «Прибыли и убытки». Таким образом, счет 90 сальдо на отчетную дату не имеет. По окончании отчетного года все субсчета, открытые к счету 90, закрывают внутренними записями на 90/9. 
Аналитический учет по счету 90 «Продажи» ведут по каж дому виду проданных товаров.

При поступлении денег от покупателей наличными или на расчетный счет за проданные товары делают запись:

Дm 50 «Касса», 51 «Расчетные счета», 52 «Валютные счета» - Km 62 «Расчеты с покупателями и заказчиками»

Если при отгрузке товаров оптовая организация получила вексель, то задолженность пок упателя учитывают на счете 62 «Расчеты с покупателями и заказчиками» субсчет «Векселя полученные».

На сумму процентов по векселю, если они предусмотрены:

Дm 62 c/сч «Векселя полученные» - Кm 98 «Доходы будущих периодов» или 91 «Прочие доходы и расходы»

При наступлении срока платежа вексель предъявлен к оплате:

Дm 51 «Расчетные счета» - Кm 62 c/сч «Векселя полученные»

При отказе покупателя оплатить век сель оптовая организация предъявляет ему претензию:

Дm 76/2 «Расчеты по претензиям» - Km 62 «Расчеты с покупателями и заказчиками "

Задолж енность по векселям, безнадежную к получению, списывают на убытки:

Дт 91 «Прочие доходы и расходы» или 63 «Резервы по сомнительным долгам» - Km $62 \mathrm{c} / \mathrm{c} 4$ «Векселя полученные» или 76/2 «Расчеты по претензиям» 
Оптовая организация может под поставку товара получать от покупателей аванс или предоплату. Полученные авансы учитывают на счете 62 «Расчеты с покупателями и заказчиками».

При поступлении суммы аванса на расчетный счет или в кассу:

Дт 50 «Касса», 51 «Расчетные счета», 52 «Валютные счета»- Km 62 «Расчеты с покупателями и заказчиками» субсчет «Авансы полученные»

С суммы полученного аванса взимается НДС, который начисляют бюдж ету следующей записью:

Дm 76 субсчет «НДС с авансов»- Кm 68 «Расчеты по налогам и сборам»

После отгрузки товаров и отражения их и НДС на счете 90 «Продажи» делают запись, уменьшающую задолженность перед бюдж етом на сумму НДС, относящегося к полученному авансу:

Дm 68 «Расчеты по налогам и сборам» - Km 76 субсчет «НДС с авансов»

Продажа товаров может осуществляться на условиях коммерческого (товарного) кредита, предоставляемого в виде отсрочки и рассрочки оплаты. За предоставляемую отсрочку платеж а продавец получает дополнительный доход в виде процентов по коммерческ ому кредиту. Сумма дохода определяется исходя из величины предоставляемого кредита и согласованной сторонами сделки кредитной ставки. Исчисленная на основании договора сумма дохода принимается к бухгалтер- 
ск ому учету в составе выручки от продаж на дату отгрузки товаров.

Организации оптовой торговли при учете продажи товаров могут работать на условиях передачи права собственности на товар по моменту оплаты с использованием последующей оплаты. При этом отгрузку покупателям товаров можно отражать с использованием счет 45 «Товары отгруженные». Товары отгруж енные учитывают на счете 45 по учетной стоимости (возможно отражение товаров по фактической стоимости с учетом расходов по отгрузке).

Отгрузку и продажу товаров покупателям в этом случае оптовая организация отраж ает следующими записями:

Отгружены покупателю товары:

Дm 45 «Товары отаруженные» - Km 41/1 «Товары на склаdax»

В этом случае отгруженные и отпущенные покупателям товары организация оптовой торговли считает своими (право собственности на них не передается) и учитывается по фактической стоимости до момента поступления оплаты за них. Покупатель, в свою очередь, может использовать или перепродать полученный товар, но при данном способе учета он будет числиться на балансе продавца до его оплаты (не учитывается переход права собственности). основанием для записей по дебету счета 45 «Товары отгруженные» являются документы на отгрузку. Реализация товаров (кредитование счета 90) при данном способе учета реализации отражается в учете на основании выписок банка с расчетного счета (при безналичных 
расчетах) или отчетов кассира (при расчетах наличными).

В момент поступления средств от покупателя:

Дт 50 «Касса», 51 «Расчетные счета», 52 «Валютные счета»- Km 90/1 «Выручка»

Списана покупная стоимость отгруженных и проданных товаров:

Дm 90/2 «Себестоимость продаж»- Km 45 «Товары отгруженные»

Начислен НДС на проданные товары:

Дm 90/3 «НДС» - Кm 68 «Расчеты по налогам и сборам»

Списаны в конце месяца расходы, приходящиеся на проданные товары:

Дm 90/2 «Cебестоимость продаж»- Кm 44 «Расходы на продажу»

Определен финансовый результат:

Дт 90/9 «Прибыль/убыток от продаж» (99 «Прибыли и убытки») - Кm 99 «Прибыли и убытки» (90/9 «Прибыль/убыток от продаж»).

Продажа товаров транзитом с участием в расчетах характеризуется тем, что товары не поступают на склады оптовых организаций и, следовательно, счет 41/1 «Товары на складах» не применяется, а моменты покупки и отгрузки отражается в учете одновременно. Продаж а товаров без участия в расчетах предполагает получение оптовой организацией от покупателей только суммы торговой надбавки за организацию оборота.

Предъявление покупателем претензий по недостачам и потерям товаров сверх предусмотренных в договоре величин 


\section{3. Учет продажи товаров}

(при вынесении судом решения о взыскании с поставщика или при признании претензий поставщиком) отраж ается следующим образом:

- сторнируется сумма продажи на взысканную покупателем сумму недостач и потерь, ранее отраженная по дебету счета 62 «Расчеты с покупателями и заказчиками» и кредиту 90 «Продажи». Одновременно указанная сумма отражается по дебету счета 62 и кредиmy счета 76 «Расчеты с разными дебиторами и кредиторами субсчет 2 «Расчеты по претензиям»;

- сторнируются обороты по дебету счета 90 «Продаж и» и к редиту счета 41 «Товары». восстановленная при этом на счете 41 сумма списывается в дебет счета 94 «Недостачи и потери от порчи ценностей».

\section{4. Учет реализации по договору комиссии}

В соответствии со ст. 990 ГК РФ по договору комиссии комиссионер обязуется по поручению комитента за вознаграждение совершить одну или несколько сделок от своего имени, но за счет комитента. К омиссионером могут выступать и оптовые и розничные посредники.

В соответствии с договором комиссии комитент передает на оговоренных условиях товары комиссионеру для последующей реализации их конечным покупателям. Таким образом, в этой операции участвуют три лица: собственник реализуемых товаров (комитент), посредник, продающий товары комитента от своего имени (комиссионер), и покупатель. К омисси- 
онер, реализуя товары комитента, оказывает комитенту услугу, за которую получает вознаграж дение - комиссионные.

В соответствии с договором комиссии комиссионер может участвовать или не участвовать в расчетах.

Если комиссионер не участвует в расчетах, то комитент самостоятельно производит расчеты с конечными покупателями, а на счет комиссионера поступает только его комиссионное вознаграждение.

Если комиссионер участвует в расчетах, то комитент производит расчеты только с комиссионером, который самостоятельно рассчитывается с конечными покупателями товаров. при этом комиссионер может получить свое вознаграждение как путем явного получения суммы комиссионного вознаграждения от комитента, так и путем удержания причитающейся ему по договору суммы из всех сумм, поступивших к нему за счет комитента.

\section{Учет у комитента}

Поскольку право собственности на передаваемые комиссионеру товары остается у комитента, то фракт передачи товаров по договору комиссии отражается записью по счету 45 «Товары отгруженные»:

Дm 45 «Товары отгруженные»- Кm 41 «Товары»

Выручка от реализации товаров и суммы НДС отражаются по времени получения извещения от комиссионера об отгрузке товара пок упателю.

Выручк ой у комитента является вся сумма, поступившая от покупателя комиссионеру, независимо от того, установлено 
комиссионное вознаграж дение в виде твердой суммы, процентов от сделки или торговой наценки.

Если покупатель оплачивает товары комиссионеру, то выручка отражается записью:

Дm 76 «Расчеты с разными дебиторами и кредиторами» субсчет «Расчеты по договору комиссии» - Кm 90/1 «Выручка»

Если покупатель оплачивает товары непосредственно комитенту, то выручка отраж ается:

Дm 62 «Расчеты с покупателями и заказчикамu» - Km 90/1 «Выручка»

При получении извещения от комиссионера об отгрузке товаров покупателю стоимость переданного комиссионеру товара списывается:

Дm 90/2 «Себестоимость продаж»- Km 45 «Товары отгруженные»

К омиссионное вознаграж дение вк лючается комитентом в состав расходов на продажу:

Дm 44 «Расходы на продажу» - Кm 76 субсчет «Расчеты по договору комиссии»

Сумма НДС, начисленная по вознаграж дению, отражается комитентом по дебету счета 19 «НДС по приобретенным ценностям» в корреспонденции с кредитом счета 76 «Расчеты с разными дебиторами и кредиторами» и затем списывается в дебет счета 68 «Расчеты по налогам и сборам» в установленном порядке.

Получение денеж ных средств за реализованные товары:

- от комиссионера (если он участвует в расчетах): 
Дm 51 «Расчетные счета» - Km 76 «Расчеты с разными дебиторами и кредиторами»

- от конечного покупателя (если комиссионер не участвует в расчетах):

Дт 51 «Расчетные счета»- Km 62 «Расчеты с покупателями и заказчиками»

\section{Учет у комиссионера}

Поскольку товары, принятые на комиссию не становятся собственностью комиссионера, они учитываются на забалансовом счете 004 «Товары, принятые на комиссию».

При реализации товаров сумма, подлежащая оплате за товары покупателями с учетом НДС по этим товарам, отражается комиссионером на дату отгрузки товаров пок упателям:

Дm 62 «Расчеты с покупателями и заказчиками» - Km 76 «Расчеты с разными дебиторами и кредиторами»

Порядок начисления комиссионного вознаграждения определяется договором. вознаграж дение может определяться в виде твердой суммы, процентов к обороту, разницы между ценой реализации и ценой, по которой товары получены от комитента.

Начисление вознаграж дения отраж ается комиссионером записью:

Дт 76 «Расчеты с разными дебиторами и кредиторами» Кm 90/1 «Выручка»

Для целей исчисления НДС деятельность комиссионера по договору комиссии рассматривается как оказание комитенту посредническ их услуг. К омиссионер определяет налого- 
вую базу как сумму дохода, полученную им в виде вознаграж дений и других доходов при использовании указанных договоров. При этом применяется ставка налога 18\% независимо от того, по какой ставке облагается реализуемый товар комитента. Суммы, полученные комиссионером от покупателей в оплату реализованных товаров комитента, в облагаемую базу по НДС не включаются, так как комиссионер не является собственником этого товара.

При начислении НДС по вознаграждению делается запись:

Дm 90/3 «НДС»- Кт 68 «Расчеты по налогам и сборам»

Погашение задолженности перед комитентом отражается:

Дт 76 «Расчеты с разными дебиторами и кредиторами» Km 51 «Расчетные счета».

\section{5. Вопросы для самоконтроля}

1. Каков порядок оценки товаров?

2. Схема учета реализации товаров по договору поставки.

3. Охарак теризуйте структуру счета 90 «Продажи».

4. Что представляет собой товарный кредит?

5. Как отражается в учете предъявление покупателем претензий?

6. Схема применения в учете счета 45 «Товары отгруженные».

7. Каковы особенности учета комиссионных операций? 


\section{ЛЕКЦИЯ 9.}

\section{УЧЕТ РОЗНИЧНОЙ РЕАЛИЗАЦИИ ТОВАРОВ}

\section{План лекции.}

1. Учет реализации товаров за наличный расчет.

2. Порядок определения валового дохода и стоимости реализованных товаров.

3. Учет возврата товаров покупателями.

4. Учет продажи товаров в кредит.

5. Комиссионная продажа товаров.

6. Вопросы для самоконтроля.

\section{1. Учет реализации товаров за наличный расчет}

Товары в рознице продают преимущественно за наличный расчет, при этом уплата денег покупателем практически совпадает по времени с передачей магазином товара покупателю. в розничных торговых предприятиях денежные расчеты с населением производятся в соответствии с Федеральным законом от 22.05.2003 г. №54-Ф3 «О применении контрольнокассовой техники при осуществлении наличных денежных расчетов и (или) расчетов с использованием платеж ных карт».

Денежные расчеты с населением производятся с обязательным применением контрольно- кассовых машин, причем применяемая контрольно-кассовая техника (ККТ) должна удо- 
влетворять следующим требованиям:

- зарегистрирована в налоговых органах;

- иметь контрольную ленту, блокирующую аппарат при ее отсутствии или обрыве;

- иметь контрольную память со сроком хранения информации до трех лет;

- обеспечивать защищенность контрольной памяти от несанкционированного доступа.

По ККТ открывают книги кассира-операциониста, индивидуальные или на несколько машин с раздельным учетом в ней каждой контрольно-кассовой машине. В ней фиксируют показатели контрольно-кассовой ленты на начало и конец рабочего дня.

Сумма выручки за проданные товары определяется как разница между показаниями счетчика ККМ на начало и конец дня. Сумма выручки еж едневно учитывается в кассовом отчете и периодически отраж ается при составлении товарного отчета.

В некоторых случаях (торговля с лотков, на ярмарках, продажа морож еного, газет и т.д.) при осуществлении торговых операций денежные расчеты с населением могут производится без применения ККМ. В этом случае объем реализованных товаров измеряют обычно суммой выручки, сданной продавцами в кассу организации, инкассатору банка или на почту.

Выручка, полученная от продажи товаров за наличный расчет, на основании отчета кассира отраж ается записью: 
Дm 50 «Касса»-Кm 90/1 «Выручка»

Торговая выручка может быть сдана в банк представителем предприятия по объявлению на взнос наличными или инкассаторам.

Выручка, переданная инкассатору или на почту (которая будет зачислена на расчетный счет по истечении определенного времени) учитывается записью:

Дm 57 «Переводы в пути» - Кm 90/1 «Выручка»

Одной из форм реализации товаров за наличный расчет является оплата покупателями товаров расчетными чеками банков. Полученные чеки магазины сдают в банк, который и зачисляет соответствующую сумму на счет торговой организации. При расчете чеками в бухгалтерском учете делается запись:

Дm 50 «Касса» субсчет 3 «Денежные документы»- Кm 90/1 «Выручка»

При учете товаров по покупным ценам после отражения выручки по счету реализации списываются реализованные товары:

Дт 90/2 «Себестоимость продаж»- Кm 41/2 «Товары в розничной торговле»

Если учет товаров ведется по продажным ценам, то учетная стоимость реализованных товаров списывается с кредита счета 41 «Товары» в дебет 90 «Продажи» субсчет 2 «Себестоимость продаж». При этом одновременно производится сторнирование суммы торговой наценки, относящейся к проданным товарам (в корреспонденции со счетом 42 «Торговая 
наценка»).

При реализации товаров по розничным ценам соответствующая сумма налога включается в указанные цены. При этом на ценниках, выставляемых продавцами, а также на чеках сумма налога не выделяется. Суммы НДС по проданным товарам отраж аются на счете 90 «Продажи» субсчет 3 «НДС».

На сумму начисленного НДС составляется проводка:

Дm 90/3 «НДС»- Кm 68 «Расчеты по налогам и сборам»

Возможен вариант, когда уплата денег предшествует переходу товара из сферы обращения в сфреру потребления (например, взнос покупателем аванса).

Предварительную оплату стоимости товаров отражают так :

Дm 50 «Касса» - Кm 62 «Расчеты с покупателями и заказчиками», с/сч «Авансы полученные»

Позднее, при отпуске товара, ранее уплаченный покупателем аванс засчитывают и отраж ают следующим образом:

Дm 62, c/сч «Авансы полученные» - Кm 90/1 «Выручка»

Возможна ситуация, когда покупателю предоставляются скидки при приобретении товаров в определенном количестве или на установленную сумму. В организации розничной торговли, ведущей учет товаров по продажным ценам, факт предоставления такой скидки отражается сторнировочной записью по дебету счета 41 «Товары» и кредиту счета 42 «Торговая наценка» на сумму предоставляемой скидки с продажной цены товаров. 
2 Порядок определения валового дохода и стоимости реализованных товаров.

\section{2. Порядок определения валового дохода и стоимости}

\section{реализованных товаров}

В организациях розничной торговли возможны различные варианты методики определения валовой прибыли и стоимости реализованных товаров.

Если в организации используется натуральностоимостной метод учета товаров (например, при использовании штрихового кодирования), то имеется возможность списывать конкретные реализованные товары по конкретным учетным ценам. При учете товаров по продаж ным ценам целесообразно по каждой партии товаров составлять ведомость с указанием по каждому наименованию покупной и продажной цены и наценки, что позволит списывать конкретную сумму торговой наценки по каждому наименованию реализованного товара.

Если в организациях розничной торговли не ведется натурально-стоимостной учет реализации или невозможно определить точный ассортимент проданных товаров, возникает необходимость списания торговой наценки косвенным расчетным путем.

При учете товаров по продажным ценам торговая наценка является валовым доходом по реализованным товарам.

Существует несколько способов расчета валового дохода, которые зависят от размера применяемых наценок, от того, насколько часто они изменяются, от возможности учета реализации товаров по их видам и т.д. Наиболее распространены следующие способы расчета валового торгового дохода: 
- исчисление по общему товарообороту;

- исчисление по ассортименту товарооборота;

- исчисление по ассортименту остатка товаров;

- исчисление по среднему проценту.

Способ расчета валового дохода по общему товарообороту

Данный способ расчета валового дохода используется в случае применения ко всем товарам одинакового процента торговой наценки в течение отчетного периода. Если ее размер в течение отчетного периода изменялся, следует определить объем товарооборота отдельно по периодам применения разных размеров торговой наценки.

Валовой доход рассчитывается по следующей формуле:

$$
\text { ВД }=\text { Т } х \mathrm{PH}: 100
$$

где ВД - валовой доход;

Т - общий товарооборот;

$\mathrm{PH}$ - расчетная торговая наценка.

В свою очередь, торговая наценка рассчитывается:

$$
\mathrm{PH}=\mathrm{TH}:(100+\mathrm{TH})
$$

где ТН - торговая наценка в процентах.

Способ расчета валового дохода по ассортименту товарооборота

Данный способ используется, если для различных групп товаров применяются различные размеры торговой наценки. Он предполагает обязательный учет товарооборота по группам товаров, каждая из которых состоит из товаров с одинаковой наценкой. 
2 Порядок определения валового дохода и стоимости реализованных товаров.

Валовой доход определяется по формуле:

$$
\text { ВД }=(\text { T1 } 1 \text { PH1 }+ \text { T2 } \times \text { PH2 }+\ldots+T n \times P H n): 100
$$

где Tn - товарооборот по группам товаров;

$\mathrm{PH}$ - расчетная торговая наценка по группам товаров.

Способ расчета валового дохода по ассортименту остатка товаров

Этот способ расчета валового дохода сходен со способом расчета валового дохода по ассортименту товарооборота и применяется в том случае, если учет товаров ведется по группам с одинаковой наценкой и известно количество товаров в каждой группе на начало и конец отчетного периода. Данный способ является наиболее точным, однако при его использовании необходимо на конец каждого отчетного периода проводить инвентаризацию.

Расчет валового дохода осуществляется по следующей формуле:

$$
\text { ВД }=\text { THн }+ \text { TH }- \text { THв }- \text { THк }
$$

где ТНн - торговая наценка на остаток товаров на начало отчетного периода (сальдо счета 42 на начало отчетного периода);

ТНп - торговая наценка на товары, поступившие за отчетный период (кредитовый оборот счета 42 за отчетный период);

ТНв - торговая наценка на товары, выбывшие за отчетный период (дебетовый оборот счета 42 за отчетный период). Под выбытием понимается документированный расход: возврат товаров поставщикам, списание порчи товаров и т.п.;

ТНк - торговая наценка на остаток товаров на конец от- 
2 Порядок определения валового дохода и стоимости реализованных товаров.

четного периода (сальдо счета 42 на к онец отчетного периода).

В свою очередь

THк $=(\mathrm{OK} 1 \times \mathrm{PH} 1+\mathrm{OK} 2 \times \mathrm{PH} 2+\ldots+\mathrm{OK} n \times \mathrm{PHn}): 100$

где Ок - остаток товаров на конец отчетного периода по группам товаров (сальдо по счету $41 / 2$ на конец отчетного периода).

Остатки товаров по наименованиям следует определять на основании инвентаризации товаров на первое число месяца, следующего за отчетным периодом.

Способ расчета валового дохода по среднему проценту

В основе расчета валового дохода по данному способу лежит расчет средней торговой наценки по реализованным товарам. При этом средняя торговая наценка (П) рассчитывается по формуле:

$$
\Pi=(T H н+T H \Pi-T H в):(T+O K) \times 100
$$

где ТНн - торговая наценка на остаток товаров на начало отчетного периода (сальдо счета 42 на начало отчетного периода);

ТНп - торговая наценка на товары, поступившие за отчетный период (кредитовый оборот счета 42);

ТНв - торговая наценка на выбывшие товары (дебетовый оборот счета 42). Под выбытием товаров в данном случае понимается так называемый док ументальный расход, т.е. возврат поставщикам, списание порчи товаров и т.п.;

Т - общий товарооборот;

ОК - остаток товаров на конец отчетного периода (сальдо счета 41 на конец отчетного периода). 
На основе рассчитанной средней наценки, учитывая товарооборот по продажным ценам, возможно определить валовой доход:

$$
\text { ВД }=\text { Т } х П: 100
$$

Реализованная торговая наценка списывается методом красного сторно проводкой:

Дm 90 «Продажи»- Кm 42 «Торговая наценка»

Это связано с тем, что по дебету и кредиту счета учета реализации отраж аются реализованные товары в одной и той же оценке (по продажным ценам).

К оррек тировка оценки товаров по дебету счета 90 «Продажи» до реальной цены их приобретения позволяет определить выручку от реализации товаров (валовой доход).

Приведенный способ расчета валового дохода прост, но не точен. Сумма торговой наценки получается больше или меньше действительной ее величины. Если, например, по сравнению со средним процентом, в числе реализованных, преобладают товары с большим процентом наценки, а в остатке преобладают товары с меньшим размером наценки, то сумма валового дохода будет заниж ена.

Уточняют сумму торговой наценки при проведении инвентаризации, проставляя против каждого наименования товара размер торговой надбавки в процентах. Умножив размер торговой наценки на суммы по каждому наименованию товаров и подсчитав общую сумму по инвентаризационной описи, сопоставляют ее с суммой, отраженной в учете на счете 42 «Торговая наценка». при этом если фрактическая скидка по 
описи меньше, чем отражено в учете, то разность корректируют сторнировочной записью:

Дm 90 «Продажи»- Кm 42 «Торговая наценка»

\section{3. Учет возврата товаров покупателями}

Порядок возврата товаров, приобретенных в розничной торговой сети, регулируется Гражданским кодексом РФ и законом РФ от 07.02.92 г. № 2300-1 «О защите прав потребителей».

Покупатель, которому продана вещь ненадлежащего качества, если ее недостатки не были оговорены продавцом, вправе по своему выбору потребовать от продавца:

- замены такой вещи вещью надлеж ащего качества;

- безвозмездного устранения недостатков вещи;

- возмещения расходов покупателя на устранение недостатк ов вещи;

- соразмерного уменьшения цены реализации;

- расторгнуть договор купли-продажи.

Если возврат производится в результате существенного нарушения продавцом условий договора по качеству, ассортименту, комплектности, упаковке или других условий поставки товара, то такой возврат рассматривается как произведенный в рамках предусмотренного зак онодательством отказа покупателя от исполнения договора купли-продажи. в этом случае договор считается недействительным, а переход права собственности на товар - несостоявшимся. 
Возвращаемый покупателем товар оформляется товарной нак ладной (ф. № ТОРГ-12).

Порядок оформления возврата денежных средств покупателю зависит от срока возврата денежных средств. если деньги возвращаются в день покупки товара, то возврат денежной суммы производится из операционной кассы магазина по выданному в этой кассе чеку ККМ. На сумму возврата денеж ных средств составляется акт по форме № K М -3. принятые от покупателя и погашенные кассовые чеки наклеивают на лист бумаги и вместе с актом сдают в бухгалтерию при кассовом отчете.

Если деньги за товар возвращаются не в день покупки или если кассовый чек покупателем утерян, то возврат осуществляется из главной кассы по расходному кассовому ордеру (ф. № К О-2) на основании письменного заявления покупателя при предъявлении документа, удостоверяющего личность.

Факт возврата покупателем товара означает, что ранее произведенная передача товаров покупателю не может быть признана продаж ей, а полученные от покупателя деньги не являются выручк ой.

При возврате товаров в бухгалтерск ом учете коррек тируется оборот по продаже и задолженность перед бюджетом по налогам.

Если товар принимается от покупателя в том же отчетном периоде, в котором он был продан, то корректировочные записи составляются со счетом 90 «Продажи». Если товар принимается в следующем за годом его продаж и отчетном перио- 
де, то корректировочные записи производятся со счетом 91 «Прочие доходы и расходы». При учете возвращенных товаров применяет счет 76 «Расчеты с разными дебиторами и кредиторами» субсчет 2 «Расчеты по претензиям».

Суммы НДС, предъявленные продавцом покупателю и уплаченные в бюджет, в случае возврата товаров продавцу подлеж ат у него вычету. Но такие вычеты производятся в полном объеме только после отраж ения в учете соответствующих операций по корректировке в связи с возвратом товаров, но не позднее одного года с момента возврата.

При возврате покупателями товаров делаются следующие корректировочные записи:

- сторнируется выручка по возвращенным товарам

Дm 76/2 «Расчеты по претензиям», 62 «Расчеты с покупателями и заказчиками» - Km 90/1 «Выручка»

- сторнируется себестоимость товаров

Дm 90/2 «Себестоимость продаж»- Km 76/2 «Расчеты по претензиям»

- возвращенный покупателем товар приходуется по цене его приобретения

Дm 41 «Товары»- Кm 76/2 «Расчеты по претензиям»

- если учет товаров ведется по продажным ценам, то отражается торговая наценка, относящаяся к возвращенному товару

Дm 41 «Товары» - Кm 42 «Торговая наценка»

- относится к вычету НДС, начисленный при продаже возвращенного впоследствии товара 
Дm 68 «Расчеты по налогам и сборам» c/cч «НДС»- Кm 76/2 «Расчеты по претензиям»

- сторнируются обороты по счету 90/3 «НДС»

Дm 90/3 «НДС»- Кm 76/2 «Расчеты по претензиям»

При возврате товаров в следующем отчетном году в бухгалтерском учете делаются следующие корректировочные записи:

- отраж ается сумма уплаченная пок упателем за товар

Дт 91/2 «Прочие расходы» - Кm 76/2 «Расчеты по претензиям»

- возвращенный товар приходуется по цене его приобретения

Дт 41 «Товары»- Кm 91/1 «Прочие доходы»

- если учет ведется по продажным ценам, то отраж ается торговая наценка, относящаяся к возвращенному товару

Дm 41 «Товары» - Кm 42 «Торговая наценка»

- относится к вычету НДС, начисленный при продаже возвращенного впоследствии товара

Дm 68 «Расчеты по налогам и сборам» c/c4 «НДС»- Кm 91/1 «Прочие доходы»

Выплату покупателю денег за возвращенный товар отраж ают записью:

Дm 76/2 «Расчеты по претензиям», 62 «Расчеты с покупателями и заказчиками» - Km 50 «Касса» 


\section{4. Учет продаж и товаров в кредит}

При реализации товаров в кредит необходимо руководствоваться Правилами продажи гражданам товаров длительного пользования в кредит, утвержденным постановлением Правительства РФ. В соответствии с этим положением решение о реализации товаров с рассрочкой платежа предприятие принимает самостоятельно.

Продажу товаров в кредит производят гражданам, работающим, обучающимся или постоянно проживающим в том же населенном пункте, где расположен магазин, при предъявлении справки, выдаваемой с места работы (учебы) или органа, назначившего пенсию.

Товары продаются по ценам, действующим на день продаж и. Передача покупателям приобретенных товаров производится при оплате не менее $20 \%$ стоимости товара, а передача товаров по цене, превышающей 12-кратный размер минимальной месячной оплаты труда, - при оплате не менее 40\% их стоимости. Остальная часть стоимости товаров оплачивается покупателями в срок от 6 месяцев до трех лет, а товаров по цене, превышающей 12-кратный размер минимальной месячной оплаты труда - до 5 лет.

При продаже товаров в кредит с пок упателей в пользу магазина взимаются проценты с суммы предоставляемого кредита, размер которых устанавливается магазином с учетом действующих процентных ставок за банковские кредиты. Последующее изменение процентных ставок за банк овск ие кредиты не влечет за собой перерасчета по процентам, уплачиваемым в 
пользу магазина.

Стоимость товара в сумме предоставляемого кредита погашается покупателем равными частями 1 раз в месяц в предусмотренные сроки .

Расчеты с покупателями за товары, проданные в кредит, могут учитываться на отдельном субсчете счета 62 «Расчеты за товары, проданные в кредит». Бухгалтерский учет операций и расчетов по продаже товаров в кредит ведется по моменту отпуска товаров, при этом в товарооборот включается вся стоимость списанных товаров.

Сумма первоначального взноса приходуется в кассу, а оставшаяся часть стоимости товара (задолженность) учитывается по счету 62 «Расчеты с покупателями и заказчиками».

Дm 50 «Касса» - на сумму первоначального взноса

Дm 62, с/с4 «Расчеты за товары, проданные в кредит» на оставшуюся сумму стоимости товара

Кm 90 «Продажи» - на всю стоимость товара, проданного в кредит.

На каждый последующий платеж делается запись:

Дm 50 «Касса» - Кm 62, с/с4 «Расчеты за товары, проданные в кредит»

Уплаченные за рассрочку платежа покупателями проценты у торговой организации отражаются следующим образом:

Дm 50 «Касса», 51 «Расчетные счета» - Кm 76 «Расчеты с разными дебиторами и кредиторами» $u$

Дт 76 «Расчеты с разными дебиторами и кредиторами» Кm 91 «Прочие доходы и расходы» 
Стоимость реализованных товаров списывается на счет реализации в обычном порядке:

Дт 90 «Продажи»- Кm 41/2 «Товары в розничной торговле»

При использовании в учете продажных цен составляется также корреспонденция красным сторно на сумму торговой наценки по товарам, проданным в кредит:

Дт 90 «Продажи»- Кm 42 «Торговая наценка»

Если торговое предприятие продает товары в кредит своим работникам, то используется счет 73 «Расчеты с персоналом по прочим операциям», субсчет 3 «Расчеты за товары, проданные в кредит»:

Дm 50 «Касса» - Кm 90/1 «Выручка» - на фрактически оплаченную сумму

Дm 73/3 «Расчеты за товары, проданные в кредит» - Km 90/1 «Выручка» - на стоимость товара, по которой предоставлен кредит.

Поступление денег в счет погашения предоставленного кредита отраж ается записью:

Дm 50 «Касса» - Кm 73/3 «Расчеты за товары, проданные в кредит»

На практике часто применяется вариант продажи товаров в кредит с участием банка, к оторый оплачивает товар торговой организации в момент заключения договора, тем самым, предоставляя кредит покупателю - физическому лицу. Проценты по кредиту оплачиваются покупателем непосредственно банку, торговая организация в этом участия не принимает и 
операции по реализации отраж ает в обычном порядке.

Продажа по кредитным картам является разновидностью продажи товаров в кредит. покупатель заключает соответствующий договор на обслуживание с кредитной фирмой и получает от нее пластиковую карту, которую использует при покупках.

Эмитенты кредитных карт (компании и банки) заключают с торговыми организациями договор о продаже товаров владельцам кредитных карт. В договоре, в частности, указываются порядок авторизации карт, обеспечение магазина необходимыми техническими средствами, условия расчетов за товары и др. К договору прилагается инструк ция о порядке обслуж ивания владельцев кредитных карт.

Авторизация карт, предъявленных в оплату товаров, заключается в проверке наличия обеспечения средств по карте. Одним из ее способов является установление связи (по телефону, компьютерным сетям) с эмитентом карт.

Продажа товаров оформляется выпиской товарных чеков (слипов), которые прокатываются на специальных машинах. Слип заполняется в трех экземплярах под копирку: первый эк земпляр вручается покупателю, второй - сдается инкассатору, третий - передается в бухгалтерию при кассовом отчете. Покупатель расписывается в слипе, подлинность его подписи проверяется работником магазина. В бухгалтерии составляются реестры, в которых указываются число слипов и суммы. Реестры со слипами сдаются в банк для зачисления на расчетный счет магазина денеж ных средств за проданные товары. 
Учет инкассированных кредитных карт можно вести на счете 57 «Переводы в пути».

При продаже товаров в розницу с помощью кредитных карт в бухгалтерск ом учете делаются следующие записи:

- отражена выручка за проданный товар. Расчет производится по кредитной карте в момент отпуска товара

Дm 62 «Расчеты с покупателями и заказчиками» - Km 90/1 «Выручка»

- начислен НДС

Дm 90/3 «НДС» - Кm 68 «Расчеты по налогам и сборам»

- списан проданный товар

Дm 90/2 «Себестоимость продаж»-Km 41/2 «Товары в розничной торговле»

- сторнирована торговая наценка (при учете товаров по продажным ценам)

Дm 90/2 «Себестоимость продаж»- Km 42 «Торговая наценка»

- переданы слипы в банк на инкассацию

Дm 57 «Переводы в пути» - Кm 62 «Расчеты с покупателями и заказчиками »

- поступили денежные средства за товары, проданные с расчетом по кредитной карте, на расчетный счет

Дт 51 «Расчетные счета» - Кm 57 «Переводы в пути»

\section{5. Комиссионная продаж а товаров}

Прием товаров на комиссию и их продажа производятся 
в соответствии с Правилами комиссионной торговли непродовольственными товарами .

Правилами установлено, что на комиссию принимают непродовольственные товары: новые и бывшие в употреблении, годные для использования, не требующие ремонта или реставрации, отвечающие санитарным нормам и требованиям.

При приеме товаров на комиссию составляется договор комиссии, в соответствии с которым одна сторона - торговое предприятие (комиссионер) принимает товар на комиссию с целью реализации за вознаграждение, а гражданин или организация (комитент) сдает товар торговому предприятию с целью его продаж и.

К роме того, составляется перечень товаров, принятых на комиссию, который является приложением к договору комиссии.

На каждый товар прикрепляют товарный ярлык, а на мелк ие недорогие вещи - ценник с указанием номера договора и продажной цены. Одновременно дают характеристику состоянию товара (новый, бывший в употреблении, степень износа, указывают другие основные товарные признаки).

Цена товара согласуется между комиссионером и комитентом и указывается в прилагаемом к договору комиссии перечне товаров, принятых на комиссию, товарном ярлыке или ценнике.

Размер комиссионного вознаграждения может быть установлен как фиксированная сумма, процент к цене, по которой продан товар или разница в ценах. 
Порядок и размеры уценки товаров согласовываются комиссионером и комитентом при заключении договора комиссии с соблюдением следующих условий:

- продажная цена товара, принятого на комиссию и не реализованного в предусмотренный договором комиссии срок, в т.ч. и после уценки, может быть снижена только при наличии согласия комитента;

- согласованный размер уценки товара устанавливают с учетом спроса и предлож ения;

- уценка одного и того же товара производится не более трех раз;

- вызов комитента для проведения первой и второй уценок товара необязателен;

- третья уценка производится с вызовом комитента. При отказе комитента от третьей уценке ему возвращают товара с возмещением комиссионеру расходов по хранению.

Деньги за проданный товар выплачивают комитенту не позднее чем на третий день после продажи. при задержке выплаты денег комиссионер уплачивает комитенту неустойку в размере, определяемом договором комиссии, но не менее 0,5\% причитающейся ему суммы за каждый день просрочк и.

Расчеты за проданный товар между комиссионером и комитентом-предприятием осуществляют, как правило, по безналичному расчету через банковские учреж дения.

Комиссионер, продавший товар по цене ниже согласованной с комитентом, обязан возместить последнему разницу, если не докажет, что у него не было возможности продать то- 
вар по согласованной цене, и продажа по более низкой цене предупредила еще большие убытк и.

В случае совершения комиссионером сделк и на условиях более выгодных, чем те, которые указаны комитентом, дополнительная выгода делится меж ду сторонами поровну.

Бухгалтерский учет товаров, принятых на комиссию, ведется на забалансовом счете 004 «Товары, принятые на комиссию», реализация товаров отражается на счете 90 «Продажи», расчеты с комитентами - на счете 76 «Расчеты с разными дебиторами и кредиторами».

Аналитический учет товаров ведется по материально ответственным лицам, индивидуально по каждой вещи, а расчетов с комитентами - по каж дому комитенту.

Суммы, полученные с комитентов за хранение вещей (если комитент забрал товары до их реализации), отражается в составе прибыли на счете 91 «Прочие доходы и расходы».

Принятие товаров по договору комиссии:

Дт 004 «Товары, принятые на комиссию»

Списание реализованных, возвращенных товаров, а также уценка товаров:

Km 004 «Товары, принятые на комиссию»

Поступление наличных денег в кассу от реализации принятых на комиссию товаров (по продажным ценам) и за хранение:

Дm 50 «Касса» - Кm 90/1 «Выручка» - на сумму выручки за реализованные товары,

Дm 50 «Касса»- Кm 91 «Прочие доходы и расходы»- на 
сумму платы за хранение товаров.

По реализованным товарам должен быть начислен НДС:

Дm 90/3 «НДС» - Кm 68 «Расчеты по налогам и сборам»

Списание издержек обращения:

Дm 90/2 «Себестоимость продаж»- Кm 44 «Расходы на продажу»

Начисление комитентам денег за проданные товары отраж ается проводкой на стоимость реализованных товаров по продажным ценам за вычетом комиссионного вознаграждения:

Дm 90/2 «Себестоимость продаж»- Km 76 «Расчеты с разными дебиторами и кредиторами»

Выплата денег комитентам:

Дт 76 «Расчеты с разными дебиторами и кредиторами» Km 50 «Касса», 51 «Расчетные счета»

Выявленный финансовый результат от реализации товаров списывается:

Дm 90/9 «Прибыль/убыток от продаж» - Кm 99 «прибыли и убытки»

Кроме того, комитентам уплачивается неустойка за задерж ку выплаты средств и поступления товара в торговый зал для продаж и, которая относится к прочим расходам:

Дт 91 «Прочие доходы и расходы»- Кm 50 «Касса»

\section{6. Вопросы для самоконтроля}

1. Какие формы расчетов за товары существуют в розничной торговле?

2. каковы правила реализации товаров за наличный рас- 


\section{5. Комиссионная продажа товаров}

чет?

3. Как мож но рассчитать сумму торговой наценк и?

4. Какой из способов расчета торговой наценки является наиболее точным?

5. Как оформляется возврат товаров пок упателями?

6. Чем отличается учет продажи в кредит от обычных форм продаж и товаров?

7. Какова схема бухгалтерского учета продаж и комиссионных товаров?

8. Особенности продажи товаров в розницу с использованием кредитных карт. 


\title{
ЛЕКЦИЯ 10.
}

\section{УЧЕТ ПОСРЕДНИЧЕСКИХ ОПЕРАЦИЙ (АГЕНТСКИЙ ДОГОВОР)}

\begin{abstract}
План лекции.
1. Учет посреднических операций (агентский договор).

2. Вопросы для самоконтроля.
\end{abstract}

\section{1. Учетпосреднических операций (агенпский договор).}

Торговая организация помимо комиссионной продажи товаров мож ет совершать и иные посредническ ие операции.

По агентск ому договору одна сторона (агент) обязуется за вознаграждение совершать по поручению другой стороны (принципала) юридическ ие и иные действия от своего имени, но за счет принципала либо от имени и за счет принципала.

Таким образом, принципал - это лицо, уполномочивающее другое лицо (в данном случае торговую организацию) действовать в качестве агента.

Агенты - это посредники, выступающие в качестве представителя другого лица, заключающие сделки от имени, по поручению и за счет принципала.

Одним из обязательных условий выполнения агентской сделки является предоставление агентом отчетов принципалу в порядке и в сроки, которые предусмотрены договором. 
1. Учет посреднических операций (агентский договор)

К отчету агента должны быть приложены необходимые док азательства расходов, произведенные за счет принципала.

Агентское соглашение относится к категории возмездных договоров, поэтому, за выполненные по агентскому соглашению действия агент получает от принципала агентское вознаграждение. Размер вознаграждения устанавливается по соглашению сторон.

Бухгалтерский учет посреднических операций у агента ведется на счете 76 «Расчеты с разными дебиторами и кредиторами » с использованием следующих субсчетов:

76/5 «Расчеты с поставщиками и подрядчиками в рамках агентского договора»;

76/6 «Расчеты с принципалом по отчету агента»

76/7 «Расчеты с принципалом по агентскому вознаграждению»

76/8 «Расчеты с принципалом по возмещаемым расходам»

76/9 «Расчеты с покупателями в рамках посреднического договора»

Приобретенные по поручению агента товарноматериальные ценности, а также полученные от агента для реализации товары подлеж ат отраж ению на забалансовом счеme 002 «Товарно-материальные ценности, принятые на ответственное хранение». Аналитический учет по счету 002 ведется по организациям-владельцам, по видам, сортам и местам хранения.

Для отражения расходов, связанных с реализацией предприятием товаров и учета издержек обращения торговых ор- 
1. Учет посреднических операций (агентский договор)

ганизаций предназначен счет 44 «Расходы на продажу».

Предприятиям, одним из видов деятельности которых является осуществление посреднических (агентских, комиссионных) операций, целесообразно применять для учета прямых затрат счет 20 “Основное производство», а для учета косвенных затрат - счет 26 «Общехозяйственные расходы».

Условно агентские соглашения можно разделить на две группы:

приобретение агентом для принципала материальных ценностей у поставщиков;

зак лючение договоров с покупателями на реализацию товаров принципала.

На практике предмет агентского договора включает в себя и ту и другую функцию.

Если агенту поручено реализовать товары, то в бухгалтерском учете торговой организации делаются следующие записи.

Приняты от принципала товары, подлежащие реализации:

Дт 002 «ТМЦ, принятые на ответственное хранение»

Товары реализованы покупателям:

Дm 62 «Расчеты с покупателями и заказчиками» - Km 76/9 «Расчеты с покупателями в рамках посреднического договора»

Кт 002 «ТМЦ, принятые на ответственное хранение»

Реализованные товары оплачены пок упателями:

Дm 51 «Расчетные счета»,52 «Валютные счета» - Кm 62 
1. Учет посреднических операций (агентский договор)

«Расчеты с покупателями и заказчиками»

Агентом предоставлен отчет принципалу:

Дm 76/9 «Расчеты с покупателями в рамках посреднического договора» - Кm 76/6 «Расчеты с принципалом по отчету агента»

Агентом начислено агентск ое вознаграждение:

Дm 76/7 «Расчеты с принципалом по аґентскому вознаграждению» - Кm 90/1 «Выручка»

Агентом удержано агентское вознаграждение из причитающейся принципалу выручки

Дm 76/6 «Расчеты с принципалом по отчету агента» Km 76/7 «Расчеты с принципалом по агентскому вознаграждению»

Перечислена принципалу выручка за минусом агентского вознаграж дения:

Дm 76/6 «Расчеты с принципалом по отчету агента» Кm 51 «Расчетные счета», 52 «Валютные счета»

Если агенту поручено приобрести материальные ценности, то делаются следующие бухгалтерские проводки .

При получении аванса от принципала в счет исполнения договора в учете торговой организации делают запись:

Дm 51 «Расчетные счета» - Km 62 c/сч «Авансы полученные»

Начисление и уплату НДС с авансовых платежей принципала отражают записями по счетам:

Дm 62 c/сч «Авансы полученные» - Кm 68 «Расчеты по налогам и сборам» 
1. Учет посреднических операций (агентский договор)

Дm 68 «Расчеты по налогам и сборам» - Km 51 «Paсчеmные счеma»

Полученные от поставщика материальные ценности отраж ают:

Дm 76/5 «Расчеты с поставщиками и подрядчиками в рамках агентского договора» - Km 60 «Расчеты с поставщиками и подрядчиками»

Полученные от поставщика товары оприходованы на хранение у торговой организации:

Дт 002 «ТМЦ, принятые на ответственное хранение»

оплата поставщику за поставленные материальные ценности отраж ается:

Дm 60 «Расчеты с поставщиками и подрядчиками» - Km 50 «Касса», 51 «Расчетные счета», 52 «Валютные счета»

Торговой организацией (агентом) предоставлен отчет принципалу:

Дm 76/6 «Расчеты с принципалом по отчету агента» Km 76/5 «Расчеты с поставщиками и подрядчиками в рамках агентского договора»

Переданы принципалу приобретенные по его поручению материальные ценности:

Кт 002 «ТМЦ, принятые на ответственное хранение»

Задолженность по расчетам с принципалом по отчету агента закрыта ранее перечисленным авансом:

Дm 62 c/сч «Авансы полученные» - Кm 76/6 «Расчеты с принципалом по отчету агента»

Начислено вознаграж дение агенту за услуги: 
1. Учет посреднических операций (агентский договор)

Дm 76/7 «Расчеты с принципалом по агентскому вознаграждению» - Кm 90/1 «Выручка»

\section{2. Вопросы для самоконтроля}

1. Сущность агентского договора?

2. Каким образом устанавливается вознаграждение агенTy?

3. Схема бухгалтерского учета расчетов по агентск ому договору. 


\section{ЛЕКЦИЯ 11.}

\section{УЧЕТ ТОВАРООБМЕННЫХ ОПЕРАЦИЙ}

План лекции.

1. Сущность товарообменных операций.

2. Учет при передаче товара с одновременным исполнением встречного обязательства.

3. Учет при получении товара до исполнения встречного обязательства

4. Учет при передаче товара до исполнения встречного обязательства

5. Вопросы для самок онтроля.

\section{1. Сущностьтоварообменных операций}

В соответствии со ст. 567 ГК РФ по договору мены каждая из сторон обязуется передать в собственность другой стороны один товар в обмен на другой.

При осуществлении товарообменной операции торговое предприятие в рамках одного договора является и покупателем и продавцом.

Договор мены должен быть заключен в простой письменной форме.

Существенными условиями договора мены являются:

- условие о наименовании товара, передаваемого каждой 
стороной;

- условие о количестве товара, передаваемого каждой стороной.

Товары, подлежащие обмену, предполагаются равноценными, если в договоре прямо не указано иное.

Если в соответствии с договором обмениваются неравноценные товары, то сторона, которая передает более дешевый товар, должна оплатить другой стороне разницу в цене непосредственно до или после передачи этого товара. В договоре стороны могут предусмотреть другой порядок оплаты.

Товарообменные операции отражаются в бухгалтерском учете в два этапа:

получение товаров от контрагента;

отгрузка товаров контрагенту.

При получении товаров по договору мены у торговой организации увеличиваются, с одной стороны, активы в виде товаров, с другой стороны, обязательства перед контрагентом. Погашение возникшей задолженности происходит путем передачи определенного товара.

При продаже товаров, с одной стороны, уменьшаются ак тивы по статье товаров, с другой стороны, возникает дебиторская задолженность покупателя за реализованные ему материальные ценности.

Возникшие по данному договору мены кредиторская и дебиторская задолж енности взаимно погашаются.

В соответствии со ст. 570 ГК РФ право собственности на обмениваемые товары переходит к контрагенту после испол- 
нения обязательств передать соответствующие товары обеими сторонами договора. Договором мены может быть предусмотрен и иной момент перехода права собственности.

2. Учет при передаче товара с одновременным исполнением встречного обязательства

При обмене имуществом в бухгалтерском учете организации отражается как продажа выбывающих материальных ценностей, так и оприходование ценностей, поступивших в обмен.

Выручка от реализации товаров признается в бухгалтерском учете на дату перехода права собственности на них к покупателю (контрагенту). Доходы по договору мены принимаются к учету в соответствии с порядком, предусмотренным п. 6.3 ПБУ 9/99.

При признании в бухгалтерск ом учете сумма выручк и от реализации товаров отражается по кредиту счета 90 «Продажи» в корреспонденции с дебетом счета 62 «Расчеты с покупателями и заказчиками». Одновременно стоимость реализованных товаров списывается в себестоимость продаж .

В свою очередь поступающие по договору мены товары (иное имущество) принимаются к бухгалтерскому учету по фактической себестоимости (первоначальной стоимости), которая определяется в порядке, установленном п. п. 5, 10 ПБУ 5/01.

Принятие к учету имущества отраж ается по дебету счета, предназначенного для учета этого имущества, и кредиту счета 
60 «Расчеты с поставщиками и подрядчиками».

Сумма выполненных контрагентом обязательств по поставке товаров (иного имущества) засчитывается в оплату реализованных ему товаров (иного имущества) записью по дебету счета 60 и кредиту счета 62.

Порядок бухгалтерского учета товарообменных операций усложняется при осуществлении операций поставки и отгрузки товара по договору мены в разных отчетных периодах. При этом возможны два варианта движения материальных ценностей:

1. Получение товара до исполнения встречного обязательства

2. Передача товара до исполнения встречного обязательства

\section{3. Учет при получении товара до исполнения встречного обязательства}

Торговая организация сначала получает товары, а в следующем отчетном периоде производит отгрузку товаров по договору мены. Так как одна из сторон не выполнила обязательство по договору, право собственности на товары не переходит от передающей стороны к получающей. Для отражения полученных товаров, в этом случае, используется счет 002 «Товары на ответственном хранении». Когда в следующем отчетном периоде торговая организация, получившая товар, произведет отгрузку товаров по договору мены, товары отражают на балансовом счете. 
Принятие к учету товаров отраж ается по дебету счета 41 «Товары» и кредиту счета 60 «Расчеты с поставщиками и подрядчиками».

Доходы по договору мены принимаются к учету в соответствии с порядком, предусмотренным п. 6.3 ПБУ 9/99.

При признании в бухгалтерск ом учете сумма выручки от реализации товаров отражается по кредиту счета 90 «Продажи» в корреспонденции с дебетом счета 62 «Расчеты с покупателями и заказчиками». Одновременно стоимость реализованных товаров списывается в себестоимость продаж .

Сумма выполненных контрагентом обязательств по поставке товаров (иного имущества) засчитывается в оплату реализованных ему товаров записью по дебету счета 60 и кредиту счета 62.

\section{4. Учет при передаче товара до исполнения встречного обязательства}

В предшествующем отчетном периоде производится отгрузка товаров, а в последующем - получение товаров в обмен на отгруженные. При передаче контрагенту товаров право собственности на них остается у организации до момента исполнения контрагентом своего обязательства по договору мены. На дату передачи товаров организация не признает выручку от реализации и балансовая стоимость переданных контрагенту товаров отражается на счете 45 «Товары отаруженные».

На дату получения товаров (иного имущества) от контр- 
4. Учет при передаче товара до исполнения встречного обязательства

агента организация признает в бухгалтерском учете выручку от реализации ему товаров. Доходы по договору мены принимаются к учету в соответствии с порядком, предусмотренным п. 6.3 ПБУ 9/99.

При признании в бухгалтерск ом учете сумма выручки от реализации товаров отражается по кредиту счета 90 «Продажи» в корреспонденции с дебетом счета 62 «Расчеты с покупателями и заказчиками». Одновременно стоимость реализованных товаров списывается со счета 45 в себестоимость продаж .

В свою очередь поступающие по договору мены товары (иное имущество) принимаются к бухгалтерскому учету по фактической себестоимости (первоначальной стоимости), которая определяется в порядке, установленном п. п. 5, 10 ПБУ 5/01.

Принятие к учету имущества отраж ается по дебету счета, предназначенного для учета этого имущества, и кредиту счеma 60 «Расчеты с поставщиками и подрядчиками».

Сумма выполненных контрагентом обязательств по поставке товаров (иного имущества) засчитывается в оплату реализованных ему товаров (иного имущества) записью по дебету счета 60 и кредиту счета 62.

Фактически с каждой стороны товарообменной сделки параллельно осуществляется реализация собственного товара в обмен на приобретение другого товара.

Оприходование товаров по покупной цене фиксируется проводкой: 
4. Учет при передаче товара до исполнения встречного обязательства

Дm 41/1 «Товары на складах» - Km 60 «Расчеты с поставщиками и подрядчиками»

Когда товары приходуются по продажной цене, то составляется дополнительная проводка на сумму торговой наценки:

Дm 41/1 «Товары на складах - Km 42 «Торговая наценка»

Отгрузка товара поставщику с предъявлением ему расчетных документов отражается как реализация записью (поставщик выступает в роли покупателя):

Дm 62 «Расчеты с покупателями и заказчиками» - Km 90 «Продажи»

После этого необходимо провести зачет задолженности покупателя стоимостью полученных от него ценностей:

Дm 60 «Расчеты с поставщиками и подрядчиками» - Km 62 «Расчеты с покупателями и заказчиками »

Реализованные товары списываются на счет по учету продаж и (по покупной цене) проводкой:

Дm 90 «Продажи»- Кm 41 «Товары»

При учете товаров по продажным ценам дополнительно сторнируется торговая надбавка:

Дm 90 «Продажи» - Km 42 «Торговая наценка»

При товарном обмене производится оценка обмениваемых товаров с целью обеспечения эквивалентности обмена, оценки возможных взаимных претензий, определения санкций и т.п.

Обычно при совершении операций мены стороны обменивают товар, равный по стоимости. Однако в договоре может 
4. Учет при передаче товара до исполнения встречного обязательства

быть предусмотрен обмен неравноценными товарами. В этом случае сторона, передающая товар, цена которого ниже цены товара, предоставляемого в обмен, должна доплатить разницу в ценах.

Бухгалтерский учет такого товарообмена дополнительно вк лючит в себя обычные операции расчетов между покупателями и поставщиками по двум возмож ным вариантам:

Товар, полученный торговой организацией, оценен дороже, чем обмениваемый, и торговая организация должна доплатить за полученные материальные ценности.

Полученный товар стоит дешевле, и поставщик должен перечислить денеж ные средства торговой организации .

Расчеты по взаимным претензиям (штрафы, уценки) при товарообменных сделках производятся путем уменьшения объема поставляемых товаров или же путем дополнительных поставок .

\section{5. Вопросы для самоконтроля}

1. Сущность договора мены.

2. Схема бухгалтерского учета при отражении товарообменных операций.

3. Особенности учета при обмене неравноценными товарами. 


\section{КОРРЕСПОНДЕНЦИЯ СЧЕТОВ (ДЛЯ ЛЕКЦИЙ 3-11)}

\begin{tabular}{|c|c|c|}
\hline Содерж ание операции & Дебет & К редит \\
\hline \multicolumn{3}{|l|}{ Учет поступления товаров } \\
\hline \multicolumn{3}{|c|}{ Учет товаров по фактической себестоимости } \\
\hline $\begin{array}{l}\text { Учет поступления товаров: } \\
\text { - фактическая себестоимость товаров } \\
\text { - НДС по поступившим товарам }\end{array}$ & $\begin{array}{c}41 \\
19 / 3\end{array}$ & $\begin{array}{l}60 \\
60\end{array}$ \\
\hline $\begin{array}{l}\text { Учет поступления товаров с использованием сче- } \\
\text { та 15: } \\
\text { - покупная стоимость товаров } \\
\text { - НДС по поступившим товарам } \\
\text { - транспортно-заготовительные расходы } \\
\text { - НДС по транспортно-заготовительным расхо- } \\
\text { дам } \\
\text { - оприходованы товары по фрактической стоимо- } \\
\text { сти }\end{array}$ & $\begin{array}{c}15 \\
19 / 3 \\
15 \\
19 / 3 \\
41\end{array}$ & $\begin{array}{l}60 \\
60 \\
60 \\
60 \\
15\end{array}$ \\
\hline $\begin{array}{l}\text { Получены товары безвозмездно: } \\
\text { - поступление товаров по рыночной стоимости } \\
\text { - при реализации стоимость товаров относится } \\
\text { на прочие доходы }\end{array}$ & $\begin{array}{c}41 \\
98 / 2\end{array}$ & $\begin{array}{l}98 / 2 \\
91 / 1\end{array}$ \\
\hline $\begin{array}{l}\text { Получены товары, приобретенные через подот- } \\
\text { четное лицо: } \\
\text { - отражаются расходы подотчетного лица } \\
\text { - стоимость приобретенного товара }\end{array}$ & $\begin{array}{l}60 \\
41\end{array}$ & $\begin{array}{l}71 \\
60\end{array}$ \\
\hline \multicolumn{3}{|l|}{ Учет товаров по учетным ценам } \\
\hline Оприходованы товары по учетным ценам & 41 & 15 \\
\hline $\begin{array}{l}\text { Формирование фрактической себестоимости то- } \\
\text { варов: }\end{array}$ & & \\
\hline $\begin{array}{l}\text { - покупная стоимость товаров } \\
\text { - НДС по поступившим товарам } \\
\text { - транспортно-заготовительные расходы } \\
\text { - НДС по транспортно-заготовительным расхо- } \\
\text { дам }\end{array}$ & $\begin{array}{c}15 \\
19 / 3 \\
15 \\
19 / 3\end{array}$ & $\begin{array}{l}60 \\
60 \\
60 \\
60\end{array}$ \\
\hline $\begin{array}{l}\text { - превышение учетных цен над фрак тической се- } \\
\text { бестоимостью (экономия) }\end{array}$ & 15 & 16 \\
\hline $\begin{array}{l}\text { - превышение фактическ ой себестоимости над } \\
\text { стоимостью по учетным ценам (перерасход) }\end{array}$ & 16 & 15 \\
\hline
\end{tabular}

Ордынская М.Е. Особенности учета в торговле. Краткий курс лекций. 


\begin{tabular}{|c|c|c|}
\hline Содерж ание операции & Дебет & К редит \\
\hline $\begin{array}{l}\text { Списываются суммы, накопленные на счете 16: } \\
\text { - перерасход } \\
\text { - экономия (сторно) }\end{array}$ & $\begin{array}{l}44 \\
44\end{array}$ & $\begin{array}{l}16 \\
16\end{array}$ \\
\hline \multicolumn{3}{|l|}{ Учет товаров по продаж ным ценам } \\
\hline $\begin{array}{l}\text { Поступили товары от поставщика: } \\
\text { - покупная стоимость } \\
\text { - НДС }\end{array}$ & $\begin{array}{l}41 / 2 \\
19 / 3\end{array}$ & $\begin{array}{l}60 \\
60\end{array}$ \\
\hline $\begin{array}{l}\text { Формируется продаж ная стоимость товаров: } \\
\text { - начислена торговая наценка } \\
\text { - НДС по стоимости товаров с учетом торговой } \\
\text { наценки }\end{array}$ & $\begin{array}{l}41 / 2 \\
41 / 2\end{array}$ & $\begin{array}{l}42 \\
42\end{array}$ \\
\hline $\begin{array}{l}\text { Транспортные расходы при приобретении това- } \\
\text { ров }\end{array}$ & 44 & 60 \\
\hline \multicolumn{3}{|l|}{ Учет расходов торговой организации } \\
\hline Начислена амортизация основных средств, НМ А & 44 & 02,05 \\
\hline Израсходованы материалы & 44 & 10 \\
\hline $\begin{array}{l}\text { Расходы по работам, услугам, вк лючаемым в за- } \\
\text { траты (транспортные, рекламные, по аренде и } \\
\text { др.): } \\
\text { - стоимость услуг без НДС } \\
\text { - НДС по услугам }\end{array}$ & $\begin{array}{l}44 \\
19\end{array}$ & $\begin{array}{l}60 \\
60\end{array}$ \\
\hline $\begin{array}{l}\text { Расходы на оплату труда: } \\
\text { - начислена зарплата } \\
\text { - начислены социальные взносы }\end{array}$ & $\begin{array}{l}44 \\
44\end{array}$ & $\begin{array}{l}70 \\
69\end{array}$ \\
\hline $\begin{array}{l}\text { Начисление налогов и других платеж ей в бюд- } \\
\text { жет, включаемых в расходы на продаж у }\end{array}$ & 44 & 68 \\
\hline Списание расходов на продаж у в конце месяца & $90 / 2$ & 44 \\
\hline $\begin{array}{l}\text { Образован резерв предстоящих расходов на опла- } \\
\text { ту отпусков, на ремонт основных средств и др. }\end{array}$ & 44 & 96 \\
\hline Начислены отпускные за счет резерва & 96 & 70 \\
\hline $\begin{array}{l}\text { Резерв израсходован на оплату ремонта основ- } \\
\text { ных средств }\end{array}$ & 96 & 60 \\
\hline $\begin{array}{l}\text { Неиспользованный резерв списывается в конце } \\
\text { отчетного периода (сторно) }\end{array}$ & 44 & 96 \\
\hline Оплата расходов будущих периодов & 97 & 51 \\
\hline $\begin{array}{l}\text { Расходы отнесены на расходы на продажу при } \\
\text { наступлении соответствующего периода }\end{array}$ & 44 & 97 \\
\hline
\end{tabular}




\begin{tabular}{|c|c|c|}
\hline Содерж ание операции & Дебет & К Кедит \\
\hline \multicolumn{3}{|l|}{ Учет тары } \\
\hline $\begin{array}{l}\text { Поступила тара от поставщиков } \\
\text { НДС по таре }\end{array}$ & $\begin{array}{c}41 / 3 \\
19\end{array}$ & $\begin{array}{l}60 \\
60\end{array}$ \\
\hline Возвращена тара поставщику & 60 & $41 / 3$ \\
\hline $\begin{array}{l}\text { Оприходована тара, стоимость которой вк люче- } \\
\text { на в стоимость товаров, но которая мож ет быть } \\
\text { использована покупателем }\end{array}$ & $41 / 3$ & $91 / 1$ \\
\hline $\begin{array}{l}\text { Изготовление тары: } \\
\text { - отражаются затраты на изготовление тары } \\
\text { - оприходована тара }\end{array}$ & $\begin{array}{c}23 \\
41 / 3\end{array}$ & $\begin{array}{l}10,70,69 \\
23\end{array}$ \\
\hline $\begin{array}{l}\text { Отраж ается стоимость тары при отгрузке поку- } \\
\text { пателю, если стоимость тары покупателем опла- } \\
\text { чивается отдельно либо тара подлеж ит возврату }\end{array}$ & 62 & $41 / 3$ \\
\hline Получена от покупателя возвратная тара & $41 / 3$ & 62 \\
\hline $\begin{array}{l}\text { Списывается залоговая тара при невозвращении } \\
\text { ее покупателем: } \\
\text { - залоговая стоимость } \\
\text { - НДС } \\
\text { - списывается себестоимость залоговой тары }\end{array}$ & $\begin{array}{c}62 \\
91 / \text { ндс } \\
91 / 2\end{array}$ & $\begin{array}{c}91 / 1 \\
68 \\
41 / 3\end{array}$ \\
\hline Расходы по ремонту тары & 44 & $\begin{array}{c}10,70 \\
60\end{array}$ \\
\hline $\begin{array}{l}\text { Списывается тара, пришедшая в негодное состо- } \\
\text { яние: }\end{array}$ & $91 / 2,94$ & $41 / 3$ \\
\hline \multicolumn{3}{|c|}{ Учет товарных потерь и переоценки товаров } \\
\hline $\begin{array}{l}\text { Отраж ена недостача товара в пределах норм } \\
\text { естественной убыли }\end{array}$ & 94 & 41 \\
\hline $\begin{array}{l}\text { Списание потерь в пределах норм естественной } \\
\text { убыли }\end{array}$ & 44 & 94 \\
\hline Списание потерь сверх норм естественной убыли & $\begin{array}{c}73 / 2,91 \\
/ 2\end{array}$ & 94 \\
\hline $\begin{array}{l}\text { Начисление резерва на списание потерь в преде- } \\
\text { лах норм естественной убыли }\end{array}$ & 44 & 96 \\
\hline Списание потерь за счет резерва & 96 & 94 \\
\hline $\begin{array}{l}\text { На сумму уценки товаров в пределах торговой } \\
\text { наценки }\end{array}$ & $41 / 2$ & 42 \\
\hline $\begin{array}{l}\text { На сумму уценки товара, превышающую вели- } \\
\text { чину торговой наценки }\end{array}$ & 91 & $41 / 2$ \\
\hline
\end{tabular}




\begin{tabular}{|c|c|c|}
\hline Содерж ание операции & Дебет & К редит \\
\hline Дооценка товаров по розничным ценам & $41 / 2$ & 42 \\
\hline $\begin{array}{l}\text { Образование резервов под сниж ение стоимости } \\
\text { материальных ценностей }\end{array}$ & 91 & 14 \\
\hline \multicolumn{3}{|l|}{ Учет результатов инвентаризации } \\
\hline Выявлена недостача товаров & 94 & 41 \\
\hline $\begin{array}{l}\text { Списание потерь в пределах норм естественной } \\
\text { убыли }\end{array}$ & 44 & 94 \\
\hline $\begin{array}{l}\text { Списание торговой наценки по недостающим } \\
\text { товарам (сторно) }\end{array}$ & 44 & 42 \\
\hline $\begin{array}{l}\text { Списание потерь сверх норм естественной убы- } \\
\text { ли при наличии виновных лиц: } \\
\text { - учетная (балансовая) стоимость недостающих } \\
\text { или испорченных товаров } \\
\text { - разница меж ду суммой, взыскиваемой с винов- } \\
\text { ного лица (рыночной стоимостью недостающих } \\
\text { товаров), и их учетной (балансовой) стоимостью }\end{array}$ & $\begin{array}{l}73 / 2 \\
73 / 2\end{array}$ & $\begin{array}{c}94 \\
98 / 4\end{array}$ \\
\hline $\begin{array}{l}\text { Поступление сумм в покрытие потерь от винов- } \\
\text { ных лиц: } \\
\text { - наличными } \\
\text { - на расчетный счет } \\
\text { - удержание из заработной платы } \\
\text { - списывается соответствующая суммам часть } \\
\text { разницы, учтенной на счете } 98 / 4\end{array}$ & $\begin{array}{c}50 \\
51 \\
70 \\
98 / 4 \\
\end{array}$ & $\begin{array}{l}73 / 2 \\
73 / 2 \\
73 / 2 \\
91 / 1\end{array}$ \\
\hline $\begin{array}{l}\text { Недостачи ценностей, выявленные в отчетном } \\
\text { году, но относящиеся к прошлым отчетным пе- } \\
\text { риодам: } \\
\text { - стоимость недостающих товаров } \\
\text { - суммы недостач относятся на виновных лиц } \\
\text { - при поступлении сумм в счет покрытия недостач } \\
\text { списываются соответствующие суммы, учтенные } \\
\text { как доходы будущих периодов }\end{array}$ & $\begin{array}{c}94 \\
73 / 2\end{array}$ & $\begin{array}{c}98 / 3 \\
94 \\
91 / 1\end{array}$ \\
\hline $\begin{array}{l}\text { Списание недостач и потерь при отсутствии ви- } \\
\text { новных лиц }\end{array}$ & $91 / 2$ & 94 \\
\hline $\begin{array}{l}\text { Списание потерь, возникших в результате сти- } \\
\text { хийных бедствий }\end{array}$ & 91 & 94 \\
\hline $\begin{array}{l}\text { Страховые возмещения по потерям от стихий- } \\
\text { ных бедствий }\end{array}$ & 51 & 91 \\
\hline
\end{tabular}

Ордынская М.Е. Особенности учета в торговле. Краткий курс лекций. $\sim 180 \sim$ 


\begin{tabular}{|c|c|c|}
\hline Содерж ание операции & Дебет & К редит \\
\hline \multicolumn{3}{|c|}{ Учет оптовой реализации товаров } \\
\hline \multicolumn{3}{|c|}{ Учет реализации по договору поставк и } \\
\hline $\begin{array}{l}\text { Отгруж ены товары покупателю: } \\
\text { - сумма, причитающаяся с покупателя (вк лючая } \\
\text { НДС) }\end{array}$ & 62 & $90 / 1$ \\
\hline - списывается себестоимость товаров & $90 / 2$ & $41 / 1$ \\
\hline - начисляется НДС по реализованным товарам & $90 / 3$ & 68 \\
\hline Оплачен товар & 50,51 & 62 \\
\hline $\begin{array}{l}\text { Списаны расходы, относящиеся к проданным } \\
\text { товарам }\end{array}$ & $90 / 2$ & 44 \\
\hline Получена предоплата от покупателей & $\begin{array}{l}50,51 \\
52\end{array}$ & 62 \\
\hline $\begin{array}{l}\text { Продаж а товаров с использованием счета 45: } \\
\text { - отгруж ены товары покупателю } \\
\text { - получены деньги от покупателя } \\
\text { - списана покупная стоимость товаров }\end{array}$ & $\begin{array}{c}45 \\
51 \\
90 / 2\end{array}$ & $\begin{array}{c}41 / 1 \\
90 / 1 \\
45\end{array}$ \\
\hline $\begin{array}{l}\text { Определен финансовый результат от продажи } \\
\text { товаров: } \\
\text { - прибыль } \\
\text { - убыток }\end{array}$ & $\begin{array}{c}90 / 9 \\
99\end{array}$ & $\begin{array}{c}99 \\
90 / 9\end{array}$ \\
\hline \multicolumn{3}{|c|}{ Учет реализации у комиссионера, если он участвует в расчетах } \\
\hline Получены товары от комитента & 004 & \\
\hline $\begin{array}{l}\text { Отгруж ены товары покупателю: } \\
\text { - отраж ение задолж енности перед комитентом } \\
\text { - списание товаров с забалансового учета }\end{array}$ & 62 & $\begin{array}{c}76 \\
004\end{array}$ \\
\hline Получена оплата от покупателей & 50,51 & 62 \\
\hline $\begin{array}{l}\text { Начислено комиссионное вознаграж дение и } \\
\text { НДС по вознаграж дению }\end{array}$ & $\begin{array}{c}76 \\
90 / 3\end{array}$ & $\begin{array}{c}90 / 1 \\
68\end{array}$ \\
\hline Погашение задолж енности перед комитентом & 76 & 51 \\
\hline \multicolumn{3}{|c|}{ Учет реализации у к омиссионера, если он не участвует в расчетах } \\
\hline Получены товары от комитента & 004 & \\
\hline Отгруж ены товары покупателю & & 004 \\
\hline Начислено комиссионное вознаграж дение & 62 & $90 / 1$ \\
\hline Получено комиссионное вознаграждение & 51 & 62 \\
\hline Начислен НДС по вознаграждению & $90 / 3$ & 68 \\
\hline \multicolumn{3}{|l|}{ Учет реализации у комитента } \\
\hline Отгруж ены товары комиссионеру & 45 & 41 \\
\hline
\end{tabular}

Ордынская М.Е. Особенности учета в торговле. Краткий курс лекций. 


\begin{tabular}{|c|c|c|}
\hline Содерж ание операции & Дебет & К редит \\
\hline $\begin{array}{l}\text { Операции при получении извещения о реализа- } \\
\text { ции: } \\
\text { - отраж ается задолж енность комиссионера (если } \\
\text { он участвует в расчетах) } \\
\text { - отражается задолженность конечного покупа- } \\
\text { теля (если комиссионер не участвует в расчетах) } \\
\text { - списывается себестоимость товаров } \\
\text { - НДС по реализованным товарам }\end{array}$ & $\begin{array}{c}62 \\
90 / 2 \\
90 / 3\end{array}$ & $\begin{array}{c}90 / 1 \\
45 \\
68\end{array}$ \\
\hline $\begin{array}{l}\text { Начислено вознаграж дение комиссионеру } \\
\text { НДС по вознаграж дению }\end{array}$ & $\begin{array}{l}44 \\
19\end{array}$ & $\begin{array}{l}76 \\
76\end{array}$ \\
\hline $\begin{array}{l}\text { Расчеты по операции (если комиссионер участ- } \\
\text { вует в расчетах): } \\
\text { - получена оплата от комиссионера за реализо- } \\
\text { ванные товара за минусом вознаграж дения } \\
\text { - зачтено вознаграж дение комиссионеру } \\
\text { - НДС по вознаграж дению предъявлен к возме- } \\
\text { щению из бюджета }\end{array}$ & $\begin{array}{l}51 \\
60 \\
68\end{array}$ & $\begin{array}{l}76 \\
76 \\
19\end{array}$ \\
\hline $\begin{array}{l}\text { Расчеты по операции (если комиссионер не } \\
\text { участвует в расчетах): } \\
\text { - получена оплата от конечного покупателя } \\
\text { - оплачено вознаграж дение комиссионеру } \\
\text { - НДС по вознаграждению предъявлен к возмещению } \\
\text { из бюджета }\end{array}$ & $\begin{array}{c}50,51 \\
60 \\
68\end{array}$ & $\begin{array}{l}62 \\
51 \\
19\end{array}$ \\
\hline \multicolumn{3}{|l|}{ Учет розничной продаж и товаров } \\
\hline \multicolumn{3}{|l|}{ Учет товаров по продаж ным ценам } \\
\hline $\begin{array}{l}\text { Поступила выручка в кассу торгового предприя- } \\
\text { тия }\end{array}$ & 50 & $90 / 1$ \\
\hline $\begin{array}{l}\text { Списана стоимость реализованных товаров по } \\
\text { продаж ным ценам }\end{array}$ & $90 / 2$ & 41 \\
\hline $\begin{array}{l}\text { Сторнируется торговая наценка по реализован- } \\
\text { ным товарам }\end{array}$ & $90 / 2$ & 42 \\
\hline Начисление НДС по реализованным товарам & $90 / 3$ & 68 \\
\hline Списание расходов на продажу & $90 / 2$ & 44 \\
\hline Определение прибыли от продажи & $90 / 9$ & 99 \\
\hline \multicolumn{3}{|c|}{ Учет товаров по фрактической себестоимости } \\
\hline $\begin{array}{l}\text { Поступила выручка в кассу торгового предприя- } \\
\text { тия }\end{array}$ & 50 & $90 / 1$ \\
\hline
\end{tabular}

Ордынская М.Е. Особенности учета в торговле. Краткий курс лекций. 


\begin{tabular}{|c|c|c|}
\hline Содерж ание операции & Дебет & К редит \\
\hline Списана себестоимость реализованных товаров & $90 / 2$ & 41 \\
\hline Начисление НДС по реализованным товарам & $90 / 3$ & 68 \\
\hline Списание расходов на продажу & $90 / 2$ & 44 \\
\hline Определение прибыли от продажи & $90 / 9$ & 99 \\
\hline \multicolumn{3}{|l|}{ Продаж а товаров в к редит } \\
\hline Отражен первоначальный взнос & 50 & $90 / 1$ \\
\hline Отраж ается сумма задолж енности покупателя & 62 & $90 / 1$ \\
\hline Списана себестоимость реализованных товаров & $90 / 2$ & 41 \\
\hline $\begin{array}{l}\text { Сторнирование торговой наценки при учете то- } \\
\text { варов по продаж ным ценам }\end{array}$ & $90 / 2$ & 42 \\
\hline $\begin{array}{l}\text { Получение денеж ных средств в счет задолж ен- } \\
\text { ности по кредиту }\end{array}$ & 50,51 & 62 \\
\hline \multicolumn{3}{|l|}{ К омиссионная продаж а товаров } \\
\hline Приняты товары на комиссию & 004 & \\
\hline Реализованы принятые на комиссию товары & 50 & $90 / 1$ \\
\hline Поступила плата за хранение товаров & 50 & $91 / 1$ \\
\hline Начислен НДС по реализованным товарам & $90 / 3$ & 68 \\
\hline $\begin{array}{l}\text { Списаны расходы на продажу комиссионного } \\
\text { товара }\end{array}$ & $90 / 2$ & 44 \\
\hline Списаны реализованные товары & & 004 \\
\hline $\begin{array}{l}\text { Начисление комитентам денег за проданные то- } \\
\text { вары за минусом комиссионного вознаграж де- } \\
\text { ния }\end{array}$ & $90 / 2$ & 76 \\
\hline Выплата денег комитентам & 76 & 50,51 \\
\hline $\begin{array}{l}\text { Выявление финансового результата от реализации то- } \\
\text { вара }\end{array}$ & $\begin{array}{l}90 / 9 \\
(99)\end{array}$ & $\begin{array}{c}99 \\
(90 / 9) \\
\end{array}$ \\
\hline \multicolumn{3}{|c|}{ Учет расчетов в рамках агентского договора } \\
\hline \multicolumn{3}{|c|}{$\begin{array}{c}\text { Приобретение агентом (торговой организацией) } \\
\text { товаров у поставщиков }\end{array}$} \\
\hline $\begin{array}{l}\text { Поступил аванс от принципала в счет исполне- } \\
\text { ния договора }\end{array}$ & 51 & $62 / \mathrm{A}$ \\
\hline Получены от поставщика товары & $76 / 5$ & 60 \\
\hline Оприходованы эти товары у агента на хранение & 002 & \\
\hline Оплачены поставщику полученные товары & 60 & 51,50 \\
\hline Предоставлен отчет принципалу & $76 / 6$ & $76 / 5$ \\
\hline $\begin{array}{l}\text { Переданы принципалу приобретенные по его } \\
\text { поручению товары }\end{array}$ & & 002 \\
\hline
\end{tabular}

Ордынская М.Е. Особенности учета в торговле. Краткий курс лекций. 


\begin{tabular}{|c|c|c|}
\hline Содерж ание операции & Дебет & К редит \\
\hline $\begin{array}{l}\text { Закрыта задолж енность по расчетам с принци- } \\
\text { палом }\end{array}$ & $62 / \mathrm{A}$ & $76 / 6$ \\
\hline $\begin{array}{l}\text { Вознаграждение за оказанные услуги по приоб- } \\
\text { ретению товаров }\end{array}$ & $76 / 7$ & $90 / 1$ \\
\hline \multicolumn{3}{|c|}{ Реализация агентом (торговой организацией) товаров } \\
\hline $\begin{array}{l}\text { Приняты от принципала товары, подлеж ащие } \\
\text { реализации }\end{array}$ & 002 & \\
\hline Товары реализованы покупателям & 62 & $76 / 9$ \\
\hline Списаны реализованные товары & & 002 \\
\hline Реализованные товары оплачены покупателями & 51 & 62 \\
\hline Предоставлен отчет принципалу & $76 / 9$ & $76 / 6$ \\
\hline Начислено агентское вознаграждение & $76 / 7$ & $90 / 1$ \\
\hline $\begin{array}{l}\text { Удерж ано агентское вознаграждение из выруч- } \\
\text { ки, причитающейся принципалу }\end{array}$ & $76 / 6$ & $76 / 7$ \\
\hline $\begin{array}{l}\text { Перечислена выручка принципалу (за минусом } \\
\text { агентского вознаграждения) }\end{array}$ & $76 / 6$ & 51 \\
\hline \multicolumn{3}{|c|}{ Учет товарообменных (бартерньх) операций } \\
\hline \multicolumn{3}{|c|}{$\begin{array}{c}\text { Учет операций при условии получения и отгрузки товаров в одном } \\
\text { отчетном периоде }\end{array}$} \\
\hline Получен товар по договору мены & 41 & 60 \\
\hline Учтен НДС, оплаченный поставщику & 19 & 60 \\
\hline Отгруж ен товар по договору мены & 62 & $90 / 1$ \\
\hline $\begin{array}{l}\text { Начислен в бюдж ет НДС по отгруж енному това- } \\
\text { ру }\end{array}$ & $90 / 3$ & 68 \\
\hline $\begin{array}{l}\text { Списан отгруж енный товар по фак тической се- } \\
\text { бестоимости }\end{array}$ & $90 / 2$ & 41 \\
\hline Предъявлен НДС бюджету & 68 & 19 \\
\hline $\begin{array}{l}\text { Произведен зачет взаимных требований по дого- } \\
\text { вору мены }\end{array}$ & 60 & 62 \\
\hline $\begin{array}{l}\text { Получены денежные средства при обмене не- } \\
\text { равноценными товарами }\end{array}$ & 51 & 62 \\
\hline $\begin{array}{l}\text { Произведена оплата поставщику при обмене не- } \\
\text { равноценными товарами }\end{array}$ & 60 & 51 \\
\hline \multicolumn{3}{|c|}{ Учет операций при условии получения товаров после отгрузки } \\
\hline Отгружен товар по договору мены & 45 & 41 \\
\hline Начислен НДС & 76/ндс & 68 \\
\hline
\end{tabular}

Ордынская М.Е. Особенности учета в торговле. Краткий курс лекций. 


\begin{tabular}{|l|c|c|}
\hline \hline \multicolumn{1}{|c|}{ Содерж ание операции } & Дебет & К редит \\
\hline Получен товар по договору мены & 41 & 60 \\
\hline Учтен НДС, оплаченный поставщику & 19 & 60 \\
\hline Отражен налоговый вычет по НДС & 68 & 19 \\
\hline $\begin{array}{l}\text { Включен в объем реализации отгруженный в } \\
\text { предыдущем периоде товар по договору мены }\end{array}$ & 62 & $90 / 1$ \\
\hline Начислен в бюджет НДС по объему реализации & $90 / 3$ & $76 /$ нс \\
\hline $\begin{array}{l}\text { Списан отгруж енный товар по фак тической се- } \\
\text { бестоимости }\end{array}$ & $90 / 2$ & 45 \\
\hline $\begin{array}{l}\text { Произведен зачет взаимных требований по дого- } \\
\text { вору мены }\end{array}$ & 60 & 62 \\
\hline \multicolumn{1}{|c|}{ Учет операций при условии отгрузки после получения товара } \\
\hline Получен товар по договору мены & 002 & \\
\hline Отражен НДС, предъявленный контрагентом & 19 & 60 \\
\hline Отражен налоговый вычет по НДС & 68 & 19 \\
\hline $\begin{array}{l}\text { Начислен НДС с полученного аванса (предопла- } \\
\text { ты) }\end{array}$ & $76 /$ ндс & $68 /$ ндс \\
\hline Признан отложенный налоговый актив & 09 & $68-п р$ \\
\hline Признана выручка от реализации товаров & 62 & $90 / 1$ \\
\hline Начислен НДС & $90 / 3$ & $68 /$ ндс \\
\hline Списана стоимость реализованных товаров & $90 / 2$ & 41 \\
\hline $\begin{array}{l}\text { Принят к вычету НДС, начисленный с аванса } \\
\text { (предоплаты) }\end{array}$ & $68 /$ ндс & $76 /$ ндс \\
\hline Погашен отложенный налоговый актив & $68-п р ~$ & 09 \\
\hline $\begin{array}{l}\text { Снят с забалансового учета ранее полученный } \\
\text { товар }\end{array}$ & 602 \\
\hline $\begin{array}{l}\text { Поставлен на балансовый учет ранее полученный } \\
\text { товар }\end{array}$ & 41 & 60 \\
\hline $\begin{array}{l}\text { Произведен зачет взаимных требований по дого- } \\
\text { вору мены }\end{array}$ & 60 & 62 \\
\hline
\end{tabular}




\section{ТЕСТОВЫЕ ЗАДАН ИЯ ДЛЯ САМ ОКОНТРОЛЯ}

Из предложенных ответов на вопросы нужно выбрать один правильный.

1. На какой стадии товар переходит из сферы обращения в сореру потребления:

а) оптовая торговля;

б) розничная торговля;

в) общественное питание.

2. Товарооборот - это:

а) движ ение товаров от производителей до потребителя;

б) общая стоимость проданных товаров;

в) разница между продажной и покупной ценой проданных товаров.

3. При доставке товаров автомобильным транспортом выписывается:

а) товарная нак ладная;

б) доверенность;

в) товарно-транспортная нак ладная

4. Основным документом по регулированию бухгалтерск ого учета товаров является:

а) Федеральный закон «О бухгалтерском учете»;

б) ПБУ 1/2008 «Учетная политика организаций»;

в) ПБУ 5/01 «Учет материально-производственных запаcoB». 


\section{5. Учет товаров по учетным ценам ведется при:}

а) слож ной структуре себестоимости товаров;

б) неотфак турованных поставках;

в) наличии товаров в пути.

6. Товары, находящиеся на оптовых базах учитываются на:

а) счете 41/1;

б) счете $41 / 2$;

в) счете $41 / 4$.

7. Товары, находящиеся на территории торгового предприятия, но не являющиеся его собственностью учитываются на:

а) балансовых счетах;

б) забалансовых счетах;

в) балансовых и забалансовых счетах в зависимости от условий, на которых они приняты в торговое предприятие.

8. Учет товаров по продажным ценам в розничной торговле ведется при:

а) узком ассортиментном наборе и изменении цен приобретения не чаще одного раза в месяц;

б) большом ассортиментом наборе товаров и отсутствии возможности ведения учета реализации товаров по каждому наименованию с конкретными покупными ценами;

в) при слож ной структуре себестоимости товаров.

9. Получен товар для к омиссионной продаж и:

а) Дт 004;

б) Дт $004-$ К т 76; 
в) Дт $41-$ К т 60 .

10. Перечислен аванс поставщику за товары:

а) Дт $62-$ К т 51;

б) Дт $60-$ К т 51;

в) Дт $51-$ Кт 62 .

11. Товар приобретен подотчетным лицом организации:

а) Дт $15-$ К т 41;

б) Дт $41 / 2-$ Кт 71;

в) Дт $71-$ Кт 50 .

12. При каком способе аналитического учета товарньх запасов контроль за их сохранностью усиливается?

а) натурально-стоимостном;

б) суммовом;

в) партионном.

13. Учет движения товаров по каждому наименованию в натуральном и стоимостном выраж ении - это:

а) по предметный учет товаров;

б) натурально-стоимостной учет товаров;

в) стоимостной учет товаров.

14. Какой вариант аналитического учета товаров используется в комиссионной торговле:

а) по предметный;

б) натурально-стоимостной;

в) стоимостной.

15. Сумма фактически поступивших товаров в розничной торговле при их учете по покупным ценам отраж ается:

а) Дт $41 / 2-$ К т 60 
Дт $19-$ К т 60;

б) Дт $41 / 1-$ Кт 60

Дт $19-$ Кт 60;

в) Дт $41 / 2-$ К т 60

$$
\begin{aligned}
& \text { Дт } 41 / 2-\text { К т } 42 \\
& \text { Дт } 19-\text { К т } 60 .
\end{aligned}
$$

16. Разница между учетной стоимостью и фактическ ой себестоимостью при учете товаров по учетным ценам отражается:
a) насчете 15;
б) на счете 16;
в) на счете 42.

17. Сущность какого метода раскрывает следующая фраза: «товары, первыми списываемые в продажу оцениваются по себестоимости последних по времени приобретений»?
а) метод ЛИФО;
б) метод ФИФО;
в) метод средней себестоимости.

18. При каком способе оценки товаров финансовый результат от продаж и будет точнее:
а) себестоимости каж дой единицы;
б) средней себестоимости;
в) способе ФИФО;
г) способе ЛИФО.

19. Какими договорами регулируется оптовая реализация товаров:

а) только договорами купли-продажи; 
б) только договорами поставки;

в) договорами поставк и, купли-продаж и, комиссии и др.

20. Если оптовая организация использует в учете счет 45 «Товары отгруж енные», то какая запись будет сделана при отгрузке товаров покупателю:

а) Дт 90/2 - К т 45;

б) Дт $45-$ К т 41;

в) Дт $62-$ К т 45 .

21. Выручка, полученная от продаж и товаров за наличный расчет, отраж ается проводк ой:

а) Дт $50-$ К т 90/1;

б) Дт $51-$ К т 90/1;

в) Дт $57-$ К т 50 .

22. Списание проданных в розницу товаров отражается записью:

а) Дт $90 / 2-$ К т $41 / 2$;

б) Дт $90 / 2-$ К т 41/3;

в) Дт $91-$ К т $41 / 4$.

23. Отраж ена выручка от продаж и комиссионных товаров:
а) Дт $50-$ К т 90/1;
б) Дт 90/1 - К т 004;
в) Дт $50-$ К т 004.

24. Какая делается запись при отражении реализованной торговой наценк и:
а) Дт $42-$ К т 99;
б) Дт 90/2 - К т 42 (сторно); 
в) Дт $42-$ Кт 90/1.

25. На каком счете отраж ается выручка от продаж и товаров, переданная инкассатору:

a) 50 «К асcа»;

б) 55 «Специальные счета в банках»;

в) 57 «Переводы в пути».

26. Какой способ расчета валового дохода используется в случае применения ко всем товарам одинакового процента торговой наценки:

а) исчисление по общему товарообороту;

б) исчисление по ассортименту товарооборота;

в) исчисление по ассортименту остатка товаров;

г) исчисление по среднему проценту.

27. Какой из способов расчета валового дохода является наиболее точным?

а) исчисление по общему товарообороту;

б) исчисление по ассортименту товарооборота;

в) исчисление по ассортименту остатка товаров;

г) исчисление по среднему проценту.

28. При учете возвращенных товаров покупателями используется счет:
a) 62 ;
б) 76 ;
B) 94 .

29. Какой проводкой отражается погашение покупателем стоимости товара в сумме предоставленного к редита?

а) Дт 50 - К т 90; 
б) Дт $62-$ К т 90;
в) Дт $50-$ К т 62 .

30. Предприятие розничной торговли продает товары по кредитным картам. Какая запись делается при поступлении денег на расчетный счет предприятия за товары, проданные с расчетом по кредитной карте:

а) Дт 57 - К т 62;

б) Дт $51-$ К т 57 ;

в) Дт $51-$ Кт 62 .

31. На каком счете отраж аются суммы, полученные с к омитентов за хранение вещей, при условии, что комитент забрал свои товары до их реализации:

а) 90 «Продажи»;

б) 91 «Прочие доходы и расходы»;

в) 99 «Прибыли и убытки».

32. На комиссию принимают:

а) только новые непродовольственные товары;

б) новые и бывшие в употреблении непродовольственные товары;

в) новые и бывшие в употреблении непродовольственные товары, а также продовольственные товары с длительным сроком хранения.

\section{3. Комиссионеры - это:}

а) посредники при заключении сделок, сводящие контрагентов друг с другом;

б) посредники, выступающие в качестве представителя другого лица при зак лючении сделок; 
в) оптовые и розничные посредники, ведущие операции от своего имени и за счет производителя.

34. Каким договором офрормляются товарообменные операции:

а) договором комиссии;

б) договором мены;

в) агентским договором.

35. Какая дополнительная проводка делается при товарообменных операциях, если полученный товар стоит дешевле переданного:
а) Дт $51-$ К т 62;
б) Дт $50-$ К т 60;
в) Дт $60-$ К т 51 .

36. На как ом счете учитывается тара-оборудование:
a) 01 ;
б) $10 / 4$;
B) $41 / 3$.

37. На каком счете учитывается стоимость тары, полученной от поставщиков бесплатно?
a) $41 / 3$;
б) 91 ;
в) 98 ;
г) 99 .

38. Сдача тары тарособирающим организациям отраж ается записью:
а) Дт $91-$ К т 41/3;
б) Дт $62-$ К т $41 / 2$; 
в) Дт 60, $76-$ К т 41/3.

39. Естественная убыль - это:

а) часть нерационального использования продукции из-за количественного уменьшения ее массы;

б) потери при перевозке, хранении и реализации товаров, обусловленные их физико-химическ ими свойствами;

в) разница между фактической массой порожней тары и ее массой по маркировке.

\section{0. Дайте наиболее правильное и полное определение} издержек обращения:

а) это часть расходов торговой организации;

б) это общественно необходимые затраты труда по доведению товаров от производителя до потребителя;

в) это затраты живого и овеществленного труда в торговых организациях в процессе движения товара от производителя до потребителя, выраж енные в денеж ной форме.

41. Какие виды затрат торговьх организаций не относятся к издерж кам обращения?

а) расходы на оплату процентов за пользование кредитом;

б) расходы, связанные с переработкой и упаковкой товаров;

в) потери товаров при их хранении.

\section{2. Номенклатура статей издерж ек устанавливается:}

а) федеральным законодательством;

б) отраслевыми методическими указаниями по учету затрат;

в) организацией самостоятельно. 
43. Текущие затраты, связанные с приобретением и продажей товаров, и затраты, связанные с капитальными и финансовыми влож ениями должны учитываться:

а) раздельно;

б) вместе.

44. Торговые организации учитывают на счете 44:

а) только расходы, связанные с упаковкой товаров;

б) только расходы, связанные с транспортировкой товаров;

в) расходы, связанные с приобретением, хранением и продажей товаров.

45. Аналитический учет по счету 44 ведется:

а) по статьям расходов;

б) по видам расходов;

в) по видам и статьям расходов.

46. Расчет издерж ек обращения на остаток товаров производится:

а) еж емесячно;

б) еж ек вартально;

в) еж егодно.

47. Какие статьи издержек обращения включаются в расчет суммы издержек обращения, приходящихся на остаток товаров?

а) транспортные расходы;

б) транспортные расходы и проценты за кредит;

в) все статьи затрат.

48. Начисление амортизации торгового оборудования 
отражается записью:

а) Дт 23 - К т 02;

б) Дт $26-$ К т 02;

в) Дт $44-$ К т 02 .

49. Списание расходов на продажу в торговьх предприятиях мож ет осуществляться:

а) в полном объеме;

б) только пропорционально себестоимости проданных товаров;

в) в полном объеме или пропорционально стоимости проданных товаров.

50. Списание недостачи товаров в пределах норм естественной убыли отраж ается:

а) Дт $94-$ К т 41;

б) Дт $44-$ К т 94;

в) Дт $44-$ К т 96.

51. Сверхнормативная убыль товара относится на виновных лиц проводк ой:

а) Дт $44-$ К т 94;

б) Дт $63-$ К т 94;

в) Дт $73-$ Кт 94 .

52. П отери товаров в результате пожара отраж ают:

а) Дт $44-$ К т 94;

б) Дт 91 - К т 94;

в) Дт $99-$ Кт 94.

53. В результате инвентаризации выявлены излишки товаров: 

а) Дт 41 - К т 91;
б) Дт 91 - К т 41;
в) Дт 41 - Кт 99 . 


\section{СПИСОК НОРМ АТИВНЫХ АКТОВ И ИСПОЛЬЗОВАННОЙ ЛИТЕРАТУРЫ}

1. Ф едеральный зак он от 21.11.96 № 129-Ф3 «О бухгалтерском учете»

2. Постановление Правительства РФ от 12.11.2002 №814 «О порядке утверждения норм естественной убыли при хранении и транспортировке товарно-материальных ценностей»

3. Положение по бухгалтерскому учету «Учет материально-производственных запасов» (ПБУ 5/01), утв. приказом М инфина России от 09.06.2001 № 44н

4. Положение по бухгалтерскому учету «Доходы организации» (ПБУ 9/99), утв. приказом М инфина России от 06.05.99 № $32 \mathrm{H}$

5. Положение по бухгалтерскому учету «Расходы организации» (ПБУ 10/99), утв. приказом М инфина России от 06.05.99 № 33H

6. Полож ение по бухгалтерск ому учету «Учетная политика организации» (ПБУ 1/2008), утв. приказом М инфина России от 06.10.2008 № 106н

7. Приказ Минфина России от 31.10.2000 № 94н «Об утверждении Плана счетов бухгалтерского учета фринансовохозяйственной деятельности предприятий и Инструкция по его применению»

8. М етодические указания по бухгалтерскому учету мате- 
риально-производственных запасов, утв. приказом Минфина России от 28.12.2001 № 119н

9. Методическ ие указания по инвентаризации имущества и финансовых обязательств, утв. приказом Минфина России от 13.06 .95 № 49

10. Агафонова М.Н. Бухгалтерский учет в оптовой и розничной торговле и документооборот. М .: ГроссМ едиа, 2006

11. Баканов М .И. Бухгалтерский учет в торговле: учеб. пособие. 2-е изд. доп и перераб. М .: Ф инансы и статистика, 2006

12. Глушков И.Е. Бухгалтерск ий (налоговый, финансовый и управленческ ий) учет на современном предприятии. Эффрективная настольная книга по бухгалтерскому учету. М .: К НОРУС, 2003

13. К амышанов П.И., Камышанов А.П. Бухгалтерск ий финансовый учет: учеб. пособие. М .: Омега-Л, 2004

14. Кувалдина Т.Б., Гончаренко Л.Н. Издержки обращения в торговле: бухгалтерский и налоговый учет: учебнопрактическ ое пособие. М .: Приор-издат, 2005

15. Матвеева В.М. Самоучитель по бухгалтерскому и налоговому учету в оптовой торговле. М .: «ДиС», 2003

16. Никандрова Л.К. Бухгалтерский учет в торговле и общественном питании. 2-е изд. М .: РИОР, 2006

17. Николаева Г.А., Блицау Л.П. Бухгалтерск ий учет в торговле. М .: Приор-издат, 2006

18. Панченко Т.М. Операции с товарами: бухучет, налогообложение. М .: Налоговый вестник, 2006

19. Холоденко Е.М ., Ростовцев А.В. Бухгалтерский учет в 
торговле. М .: Издательство «Экономик с Пресс», 2004

20. Экономика торговли: учеб. пособие для нач. проф. образования / Г.Г. Иванов. 2-е изд., стер. М .: Издательский центр «Академия», 2007 